Jorge Luiz Dias de Frias

Uma ferramenta para a obtenção e análise de dados do ENEM.

Dissertação apresentada como requisito parcial para a obtenção do grau de Mestre pelo programa de Pósgraduação em matemática do Departamento de Matemática da PUC-Rio.

Orientador: Prof. Sinésio Pesco

Co - orientador: Prof. Paulo Cezar Pinto Carvalho 
Jorge Luiz Dias de Frias

\section{Uma ferramenta para a obtenção e análise de dados do}

ENEM.

Dissertação apresentada como requisito parcial para a obtenção do grau de Mestre pelo Programa de Pós-Graduação em Matemática do Departamento de Matemática do Centro Técnico Científico da PUC-Rio. Aprovada pela Comissão Examinadora abaixo assinada.

Prof. Sinésio Pesco

Orientador

Departamento de Matemática - PUC-Rio

Prof. Paulo Cezar Pinto Carvalho

Co-orientador

Instituto Nacional de Matemática Pura e Aplicada - IMPA

Prof. Antônio Carlos Saraiva Branco

Fundação Getúlio Vargas - FGV

Prof. Wanderley Moura Rezende Instituto de Matemática - UFF

Prof. José Eugenio Leal Coordenador Setorial do Centro Técnico Científico - PUC - Rio

Rio de Janeiro, 31 de março de 2015 
Todos os direitos reservados. Proibida a reprodução total ou parcial do trabalho sem autorização da universidade, do autor e do orientador.

\section{Jorge Luiz Dias de Frias}

Graduado em Licenciatura em Matemática pela Universidade do Estado Rio de Janeiro em 1977. Graduado em Administração de Empresas pela Universidade Estácio de Sá em 1999. PósGraduado em Planejamento e Administração Escolar pela Universidade do Estado do Rio de Janeiro em 2004.

Coordenador do Colégio Israelita Brasileiro A. Liessin Scholem Aleichem desde 2007. Trabalhos anteriores: Professor, Coordenador e Diretor do Colégio Bahiense de 1979 a 2006; Professor do Colégio Militar do Rio de Janeiro; Professor do Colégio Brigadeiro Newton Braga; Professor do Colégio Estadual Sobral Pinto.

Ficha Catalográfica

Frias, Jorge Luiz Dias de

Uma ferramenta para a obtenção e análise de dados do ENEM / Jorge Luiz Dias de Frias; orientador: Sinésio Pesco; co-orientador: Paulo Cezar Pinto Carvalho. 2015.

97 f.: il. (color.) ; $30 \mathrm{~cm}$

Dissertação (mestrado)-Pontifícia Universidade Católica do Rio de Janeiro, Departamento de Matemática, 2015.

Inclui bibliografia

1. Matemática - Teses. 2. Teoria da Resposta ao Item. 3. ENEM. 4. Avaliação da Educação. I. Pesco, Sinésio. II. Carvalho, Paulo Cezar Pinto. III. Pontifícia Universidade Católica do Rio de Janeiro. Departamento de Matemática. IV. Título. 
Dedico este trabalho à minha esposa Lúcia, às minhas filhas Lígia e Luciana e a meus netos Kauã e Kayke. 


\section{Agradecimentos}

A todos os professores que contribuíram para este trabalho de conclusão, em especial ao meu orientador, Professor Sinésio Pesco. Da mesma forma ao meu co-orientador Professor Paulo Cezar Pinto Carvalho.

À Sociedade Brasileira de Matemática por proporcionar o curso de mestrado a professores que não trabalham em rede oficial de ensino.

À minha esposa Lúcia pelo apoio que tem me dado nestes 41 anos de convivência, pois acreditou em cada um dos meus sonhos e sempre me ajudou a torná-los realidade.

Ao Professor Carlos Nehab que numa apresentação sua na FGV me fez ver os dados do ENEM de uma forma diferente da que eu percebia até então. 


\section{Resumo}

Frias, Jorge Luiz Dias de; Pesco, Sinésio (orientador); Carvalho, Paulo Cezar Pinto (co-orientador). Uma ferramenta para a obtenção e análise de dados do ENEM. Rio de Janeiro, 2015. 97 p. Dissertação de Mestrado - Departamento de Matemática, Pontifícia Universidade Católica do Rio de Janeiro.

Este trabalho de conclusão de curso tem dois objetivos. O primeiro, tornar acessível aos Diretores, Coordenadores e Professores os dados dos seus alunos que participaram do Exame Nacional do Ensino Médio (ENEM) 2012, divulgados pelo INEP através dos Microdados do ENEM 2012, por intermédio de uma ferramenta que permite conhecer, analisar, tomar decisões e criar estratégias para $\mathrm{o}$ aprimoramento do projeto pedagógico do Estabelecimento de Ensino. O segundo objetivo é o de capacitar pessoas para obter estes dados e desenvolver as suas próprias ferramentas utilizando o programa Excel.

\section{Palavras chave}

Teoria da Resposta ao Item; ENEM; Avaliação da Educação. 


\section{Abstract}

Frias, Jorge Luiz Dias de; Pesco, Sinesio (Advisor); Carvalho, Paulo Cezar Pinto (Co-Advisor). A tool to obtain and analyse "ENEM" data. Rio de Janeiro, 2015. 97 p. MSc. Dissertation - Departamento de Matemática, Pontifícia Universidade Católica do Rio de Janeiro..

The present work aims at achieving two objectives. The first one is to make it accessible to principals, coordinators and teachers, data about their students who took part in ENEM ("Exame Nacional do Ensino Médio" / High School National Exam) in 2012. This data was released by INEP, a governmental institute, based on each candidate's information on the test. The tool used to get this data makes it possible to obtain, analyse, make decisions and create strategies to improve the pedagogic plan of the school. The second objective is to train people to get this data and develop their own tools using the Microsoft Office Excel.

\section{Keywords}

Item Response Theory; ENEM; Education Evaluation. 


\section{Sumário}

1 Introdução 14

2 Teoria de Resposta ao Item (TRI) 16

2.1. Histórico 16

2.2. O novo ENEM 18

2.2.1. Objetivos do Exame 18

2.2.2. Características do Exame 18

2.2.3. Formato do Exame 19

2.2.4. Correção da Redação 20

2.3. Metodologia da Teoria da Resposta ao Item (TRI) 21

2.3.1. Métrica do item 21

2.3.2. Correção 23

3 Interpretação dos dados $\quad 27$

3.1. Resultados divulgados pelo INEP 27

3.2. Resultados obtidos nos microdados do ENEM 2012

3.2.1. Distribuição dos alunos de acordo com as notas obtidas 29

3.2.2. Desempenhos dos alunos em cada área de conhecimento 38

4 Ferramentas para extrair dos dados fornecidos pelo INEP os dados de uma determinada escola 49

4.1. O passo a passo 50

4.1.1. Onde encontrar os dados disponíveis 50

4.1.2. A Pesquisa e as Ferramentas 53

5 Aplicativo $\quad 68$

6 Conclusão $\quad 69$

$\begin{array}{ll}\text { Referência bibliográfica } & 72\end{array}$ 
7 Apêndices

73

7.1. Apêndice 1

7.1.1. Matriz de referência 73

7.2. Apêndice 2

7.2.1. Tabelas para consulta diferente do Estado do Rio de janeiro $\quad 95$

Tabela 3 - Dados do aluno. 95 


\section{Lista de figuras}

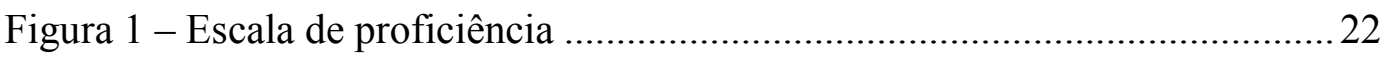

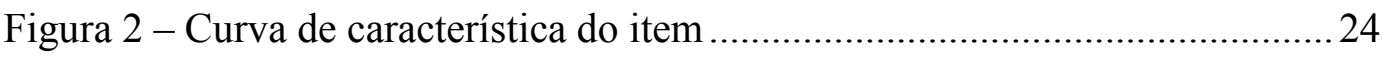

Figura 3 - Posicionamento na métrica do ENEM de 2 alunos ................................. 25

Figura 4 - Comparativo entre dois alunos com acertos diferentes.......................... 26

Figura 5 - Comparativo entre as notas dos alunos do colégio A. Liessin e dos

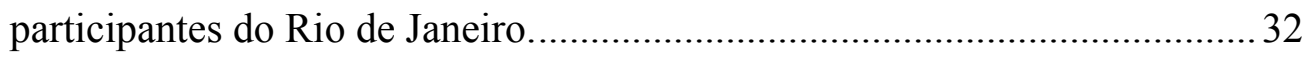

Figura 6 - Ciências da Natureza - Alunos do Colégio A. Liessin .......................... 33

Figura 7 - Ciências da Natureza - Participantes do Rio de Janeiro........................... 33

Figura 8 - Ciências Humanas - Alunos do Colégio A. Liessin ................................ 34

Figura 9 - Ciências Humanas - Participantes do Rio de Janeiro............................... 34

Figura 10 - Linguagem e Códigos - Alunos do Colégio A. Liessin....................... 35

Figura 11 - Linguagens e Códigos - Participantes do Rio de Janeiro .....................35

Figura 12 - Matemática - Alunos do Colégio A. Liessin ........................................ 36

Figura 13 - Matemática - Participantes do Rio de Janeiro ........................................36

Figura 14 - Redação - Alunos do Colégio A. liessin ............................................. 37

Figura 15 - Redação - Participantes do Rio de Janeiro ………………………....... 37

Figura 16 - Ciências da Natureza - Porcentagem de acertos por questão .............. 38

Figura 17 - Ciências Humanas - Porcentagem de acertos por questão .................. 39

Figura 18 - Matemática - Porcentagem de acertos por questão …………………....39

Figura 19 - Linguagens e Códigos- Porcentagem de acertos por questão ............. 40

Figura 20 - Ciências da Natureza - Importância X Proficiência .............................. 41

Figura 21 - Ciências Humanas - Importância X Proficiência ................................. 41

Figura 22 - Linguagens e Códigos - Importância X Proficiência ........................... 42

Figura 23 - Matemática - Importância X Proficiência ............................................. 42

Figura 24 - Ciências da Natureza - Distribuição dos alunos do Rio de Janeiro em relação ao número de acertos.

Figura 25 - Ciências Humanas - Distribuição dos alunos do Rio de Janeiro em relação ao número de acertos. 44

Figura 26 - Códigos e Linguagens - Distribuição dos alunos do Rio de Janeiro em relação ao número de acertos.

Figura 27 - Matemática - Distribuição dos alunos do Rio de Janeiro em relação ao número de acertos 
Figura 28 - Ciências da Natureza - Máximo e mínimo por número de acertos ... 46

Figura 29 - Ciências Humanas - Máximo e mínimo por número de acertos ........ 47

Figura 30 - Códigos e Linguagens - Máximo e mínimo por número de acertos . 47

Figura 31 - Matemática - Máximo e mínimo por número de acertos ................... 48

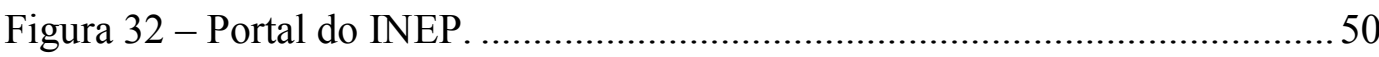

Figura 33 - Informações estatísticas. ............................................................ 51

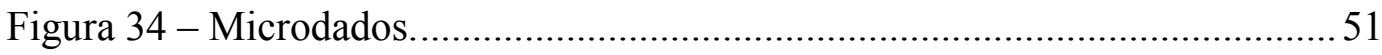

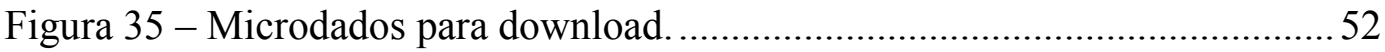

Figura 36 - Microdados ENEM (ano que deseja a informação). .......................... 52

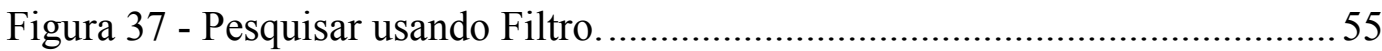

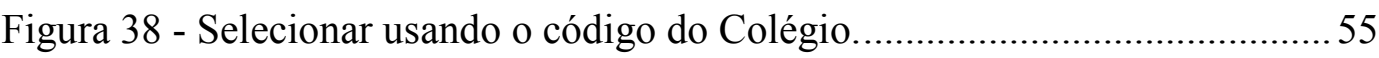

Figura 39 - Matemática - Distribuição de alunos...................................................56

Figura 40 - Construção de gráfico de frequência.................................................. 58

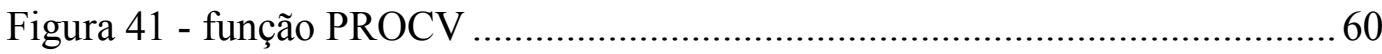

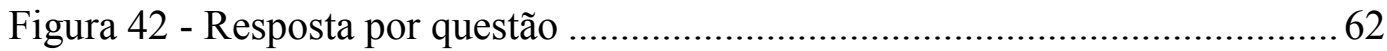

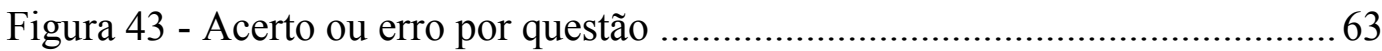

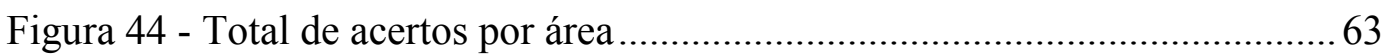

Figura 45 - Relação entre as questões de cada cor das provas ............................... 64

Figura 46 - Soma dos acertos por prova e por questão dos alunos de uma escola 65

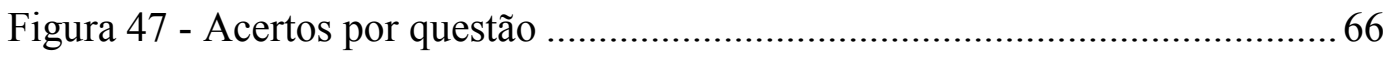

Figura 48 - Percentual de acertos por questão ..................................................... 66

Figura 49 - Tabela e gráfico da média de acertos por habilidade.......................... 67 


\section{Lista de Tabelas}

Tabela 1 - Notas dos alunos do Colégio A. Liessin ............................................... 30

Tabela 2 - Matemática - Distribuição dos alunos do A. Liessin por suas notas. ... 57 
Perseverança não é uma corrida longa, são muitas corridas curtas, uma após a outra. 


\section{Introdução}

Desde a constituição de 1988, no artigo 206, a União tem a incumbência de garantir a qualidade de ensino em todo território Nacional e, especificamente no Ensino Médio, desde 1998, vem aplicando o Exame Nacional do Ensino médio (ENEM).

O Instituto Nacional de Ensino e Pesquisa Anísio Teixeira (INEP) responsável por esta avaliação, em 2009, mudou as características do exame e o novo ENEM passou a utilizar uma metodologia de correção baseada na Teoria da Resposta ao Item (TRI).

Esta teoria, a princípio vista como novidade para a grande maioria das pessoas, existia havia 50 anos, e no Brasil era aplicada desde 1995 no Sistema Nacional de Avaliação da Educação Básica (SAEB).

Dentre os objetivos do novo ENEM, dois chamam a atenção de modo particular; ser entrada para o ensino superior, pois desde 2009 as universidades federais passaram a aceitá-lo como forma de ingresso exclusivo ou parcial; e, promover a avaliação das escolas de ensino médio, de forma que cada escola receba o resultado de seus alunos de forma global.

O primeiro objetivo está sendo plenamente atendido, visto que cada vez mais universidades federais participam deste projeto do governo. O segundo, por sua vez, não é atingido em sua forma plena, pois o governo fornece os dados, no entanto, as escolas em sua quase totalidade não têm condições de obtê-los.

Algumas informações das escolas de Ensino médio são divulgadas de modo claro, tais como as médias em cada área do conhecimento e a média de redação. Porém, os dados informando como foram os alunos individualmente e em cada área do conhecimento, embora disponibilizados nos microdados fornecidos na página do INEP, não são utilizados pelas escolas ou por falta de tecnologia ou por falta de conhecimento.

Sou coordenador de Ensino Médio desde 1994 e do Colégio Israelita Brasileiro A. Liessin Scholem Aleichem, desde 2007. Por muitos anos a 
frustração de não obter estes dados era grande, por isso, a minha pesquisa tinha como foco principal identificar que tecnologia era necessária e que conhecimentos eu tinha que dominar para atingir os meus objetivos.

O primeiro problema era técnico, e consistia em transformar os dados do ENEM 2012 disponibilizados pelo INEP, em uma ferramenta que eu dominasse e que pudesse após extrair os dados fazer uma análise que fosse de interesse da direção do Colégio, dos coordenadores, seus professores e dos alunos que fariam o exame no ano seguinte. Por esta razão optei pelo programa Excel 2010 da Microsoft. O arquivo texto fornecido na página, denominado Microdados 2012, ao ser transformado em um arquivo Excel apresenta aproximadamente oito milhões de linhas. Qualquer arquivo do Excel tem no máximo um milhão de linhas, por isso, havia o impedimento para baixar o arquivo.

O segundo problema era de ordem cognitivo, pois o conhecimento que eu tinha não era suficiente para resolver os problemas que se apresentavam. Portanto, eu tive que aprender de acordo com a necessidade algumas ferramentas que fazem parte do Excel, mas, que não são utilizadas normalmente pelos usuários.

Estes dois desafios me instigaram a buscar as respostas e as parcerias para desenvolver um aplicativo onde ao indicar o código do colégio fosse possível obter a proficiência de cada aluno em cada área do conhecimento, a sua nota de redação e a distribuição da mesma em cada competência, da mesma forma, conhecer que questões foram acertadas ou erradas e que habilidades foram contempladas nos exames e o desempenho dos alunos em cada uma das habilidades.

O objetivo deste trabalho é apresentar um aplicativo que atenda as necessidades mencionadas acima e que qualquer usuário, de acordo com suas necessidades, seguindo as etapas apresentadas consiga atingir os seus objetivos.

Nos capítulos seguintes apresentarei um histórico do ENEM, a metodologia da TRI; os dados do colégio onde sou coordenador e as respectivas análises; as ferramentas para que qualquer pessoa com conhecimento em Excel consiga obter os dados do seu colégio e finalmente o aplicativo que desenvolvi para obter estes dados. 


\section{2 \\ Teoria de Resposta ao Item (TRI)}

\subsection{Histórico}

A maioria das pessoas passou a ouvir falar de TRI a partir de 2009, quando o INEP (Instituto Nacional de Ensino e Pesquisa Anísio Teixeira) informou quais seriam as novas regras do ENEM (Exame Nacional do Ensino Médio) a partir daquele ano.

O interesse em conhecer o objetivo e as técnicas aplicadas pelo TRI fez com que a área educacional se mobilizasse e palestras e seminários aconteceram em todo território nacional. Poucas pessoas dominavam o assunto e até hoje a grande maioria ainda o desconhece.

O INEP em 2009 divulgou que o ENEM sofreria as seguintes mudanças:

$\mathrm{Na}$ sua forma - até 2008 o exame era constituído de uma redação e 63 questões objetivas realizadas em um único dia, a partir de 2009, o exame passou a ter uma redação e 180 questões objetivas divididas em quatro áreas de conhecimento e aplicado em dois dias seguidos;

$\mathrm{Na}$ correção - o ENEM seria corrigido pela TRI que tem como base a possibilidade de medir o traço latente do aluno, isto é, medir o conhecimento do aluno utilizando as informações de um banco de itens pré testados em um grupo determinado. São definidos parâmetros característicos da TRI e é possível comparar um novo grupo de testandos utilizando recursos estatísticos e probabilísticos. As notas dos alunos são calculadas a partir de uma média e um desvio padrão estabelecidos.

$\mathrm{Na}$ utilização dos resultados - até 2008 poucas universidades utilizavam o resultado do ENEM, no Rio de Janeiro apenas a PUC usava o resultado do aluno como forma de ingresso na universidade. A partir de 2009 o governo convocou as universidades públicas a usarem o resultado do ENEM como ingresso exclusivo ou parcial nos seus exames admissionais. O governo criou o SISU (Sistema de Seleção Unificada) para que as universidades de todo o Brasil pudessem receber os alunos inscritos no vestibular, que passa ser via internet e o aluno se inscreve 
de acordo com a sua nota, ou seja, o aluno faz a prova, recebe uma nota e com esta nota faz a sua inscrição, na carreira que desejar, em universidades do Brasil que optem por receber alunos pelo SISU.

Começa então uma comoção nacional, pois contrariando a Teoria Clássica dos Testes, onde o escore do aluno está diretamente ligado ao número de acertos, a TRI pressupõe que o escore do aluno não depende apenas da quantidade de acertos, mas da coerência dos acertos nas suas respostas, isto é, espera-se que o aluno acerte as questões fáceis e médias.

Mas afinal, que novidades são estas? Perguntavam todos ligados à educação. Antes de revelar cada integrante deste novo processo vamos entender como esta teoria se desenvolveu.

De acordo com Pasquali (1), no início dos anos 50, baseados em seus precursores: Richardson (1936) que comparou os parâmetros dos itens obtidos pela Teoria Clássica da Psicometria com os que são usados atualmente pelo TRI; Lawley (1943) cujos trabalhos determinavam métodos para estimar os parâmetros dos itens; Tucker (1946) que foi a primeiro a usar a curva ICC (Iten Characteristic Curve) e Lazersfeld (1950) que introduziu a ideia de traço latente; Frederic Lord (1952) elaborou um modelo teórico e métodos para determinar os parâmetros da TRI. Lord utilizava em seus estudos curvas em forma de ogivas. Eram aplicados em testes dicotômicos, ou seja, certo ou errado, sim ou não, verdadeiro ou falso. Birnbaum (1957) substituiu as curvas no formato de ogivas por curvas logísticas, usando logaritmo o que facilitava o trato matemático. Em seguida Samejima (1969) aprimora a teoria aplicando-a em testes politômicos. A partir dos anos 80 com o avanço da informática softwares foram sendo desenvolvidos para maior rapidez e confiabilidade no processo.

O governo brasileiro baseado da Constituição de 1988 passa a ter a competência de avaliar e garantir a qualidade do sistema educacional brasileiro. Cria os PCN (Parâmetros Curriculares Nacionais) que passariam a balizar o ensino a partir de avaliações de larga escala.

Em 1990 é aplicado o SAEB (Sistema Nacional de Avaliação Educacional Brasileira). No ano de 1995 esta avaliação é reestruturada e aplicada utilizando pela primeira vez a TRI, possibilitando a comparação de grupos diferentes ao longo dos anos. 
O ENEM foi implantado em 1998, e a ideia central era avaliação de competências (eram 21 no total), com provas contextualizadas e interdisciplinares. Abrangiam as diversas áreas de conhecimento, constava de 63 questões (cada competência era avaliada 3 vezes).

Em 2009, este exame passa por uma reformulação. Assim como no SAEB e na Prova Brasil, o governo passa a ter uma série histórica, pois com a utilização da TRI, é possível comparar grupos diferentes com provas diferentes. É uma avaliação com caráter probabilístico, portanto, muda o paradigma de que - a nota do aluno é proporcional ao número de questões que acerta, para - é possível medir de forma mais adequada o traço latente do aluno, ou seja, o quanto ele domina daquela área de conhecimento, dependendo de que questões o aluno acerta.

\subsection{0 novo ENEM}

\subsubsection{Objetivos do Exame}

A partir de 2009, o ENEM passa a ser um dos processos seletivos de Instituições de Educação Superior com os seguintes objetivos:

- Democratizar as oportunidades de concorrência às vagas federais de Ensino Superior.

- Certificar jovens e adultos no Ensino Médio, atribuição que era do ENCCEJA (Exame Nacional para Certificação de Competências de Jovens e Adultos).

- Direcionar a construção e revisão dos currículos das escolas de Ensino Médio.

\subsubsection{Características do Exame}

As Matrizes de Referência são os documentos que servem de base à elaboração dos itens (ou questões) que compõem as provas. O item é a unidade básica do instrumento de medida (INEP).

O exame é dividido em quatro áreas de conhecimento:

(i) Linguagens, Códigos e suas Tecnologias (incluindo redação);

(ii) Ciências Humanas e suas Tecnologias;

(iii) Ciências da Natureza e suas Tecnologias; 
(iv) Matemática e suas Tecnologias

Até 2009 línguas estrangeiras não eram avaliadas, a partir do novo ENEM, Espanhol e Inglês foram incluídas na avaliação. Desta forma, domínio de linguagens, compreensão de fenômenos, enfrentamento de situações problema, construção de argumentação e elaboração de propostas são competências que correspondem aos eixos cognitivos básicos. Espera-se, portanto, que todo jovem ou adulto deve ter desenvolvido estas habilidades para enfrentar os desafios que são apresentados diariamente.

Cada uma das áreas de conhecimento foi dividida em competências, discriminadas de forma mais ampla e as competências subdivididas em habilidades, que foram descritas de forma mais específicas.

Temos então cinco eixos cognitivos, divididos em quatro áreas de conhecimentos, cada área com determinado número de competências, num total de 30 habilidades cada uma. Os eixos, as competências por área de conhecimento e as suas respectivas habilidades estão discriminados no Apêndice I.

Se cada área de conhecimento apresenta 45 questões, e se todas as habilidades a priori devem ser contempladas, algumas vão aparecer mais de uma vez em cada exame.

O exame é composto por questões objetivas, pré-testadas, que formam um banco de questões que está sendo construído pelo INEP ao longo destes anos.

\subsubsection{Formato do Exame}

Em cada uma das áreas as provas são constituídas por 45 questões objetivas, são utilizadas quatro tipos de provas de cores diferentes que diferem apenas na posição das questões, ou seja, as provas de cada área possuem as mesmas questões, mas alocadas em diferentes posições, a questão 1 na prova amarela de matemática de 2012, por exemplo, corresponde à questão 10 na prova cinza, à $9^{\mathrm{a}}$ na azul e à $22^{\mathrm{a}}$ na rosa.

O exame é realizado em dois dias de um final de semana, no sábado os alunos respondem a 90 questões e são avaliados nas provas de Ciências Humanas que abrange História, Geografia, Filosofia e Sociologia, e em Ciências da Natureza, com questões de Física, Química e Biologia. 
No domingo, as provas são de Matemática, com 45 questões, assim como, Linguagens e Códigos que contemplam Língua portuguesa e Literatura Brasileira, Língua estrangeira, o aluno opta por inglês ou espanhol, Artes e Educação Física. O aluno ainda deve produzir um texto.

O método de avaliação tem um caráter probabilístico e por isso tem um número elevado de questões que devem ser feitas em 4h30minutos, o que significa que o exame deve ser realizado com uma velocidade de 3 minutos por questão, o que para a grande maioria dos alunos é muito difícil de ser executado. A redação também tem tempo previsto de uma hora, apertado também para a grande parte dos alunos.

\subsubsection{Correção da Redação}

Na página do Inep, no que se refere a redação, temos que a nota é dividida em 5 competências, a saber:

Competência 1 - Demonstrar domínio da modalidade escrita formal de Língua Portuguesa.

Competência 2 - Compreender a proposta de redação e aplicar conceitos das várias áreas de conhecimento para desenvolver o tema, dentro dos limites estruturais do texto dissertativo-argumentativo em prosa.

Competência 3 - Selecionar, relacionar, organizar e interpretar informações, fatos, opiniões e argumentos em defesa de um ponto de vista.

Competência 4 - Demonstrar conhecimento dos mecanismos linguísticos necessários para a construção da argumentação.

Competência 5 - Elaborar proposta de intervenção para o problema abordado, respeitando os direitos humanos.

Cada um dos textos é copiado e enviado a dois corretores distintos que realizam suas correções sem saber as notas do outro avaliador. Cada competência recebe nota de 0 a 200 pontos, com intervalos de 40 pontos, ou seja, em cada competência as notas possíveis dadas por um avaliador são: $0,40,80,120,160$ ou 200. A nota do examinando será a média aritmética das notas finais.

Se por ventura a diferença entre as notas de uma determinada competência for maior que 80 , ou, se na totalização das competências a diferença for maior que 100 pontos, considera-se que houve discrepância e a prova é corrigida por um 
terceiro corretor. A nota final será a média aritmética entre as notas que mais se aproximarem.

\subsection{Metodologia da Teoria da Resposta ao Item (TRI)}

Uma comparação com a avaliação utilizando a metodologia da TRI é a de um atleta de salto à altura. Imagina-se que ele já passou por uma prova de qualificação que garantiu a ele competir e quanto no mínimo deve se esperar deste atleta, portanto, inicia-se a prova com uma determinada altura, se o atleta passa pela prova e mostra uma desenvoltura que indica uma possibilidade de aumentar a altura em $30 \mathrm{~cm}$, na próxima o sarrafo estará nesta nova altura, se, no entanto, não conseguir ultrapassar, diminui-se em, por exemplo, $15 \mathrm{~cm}$, se mais uma vez obtém êxito, torna-se aumentar, e assim balanceamos as alturas até concluirmos que em determinada altura o atleta está atingindo o seu potencial máximo.

Desta forma, qualquer atleta, mesmo que não consiga completar a prova, não terá nota zero, pois seu histórico de vida dá garantia de um mínimo necessário para chegar a esta competição.

O exame proposto pelo INEP também vê assim o aluno concluinte do ensino médio. O governo acredita que este examinando já traz uma bagagem que o qualifica, e que garante um mínimo de conhecimento frente às exigências que se colocarão no cotidiano.

Segundo Andrade, a TRI é um modelo matemático que determina a probabilidade de um indivíduo dar uma resposta a um item em função de parâmetros do item e da habilidade do respondente. Leva-se em conta para a aplicação da TRI três fatores:

i) A natureza do item - Dicotômico ou não dicotômico.

ii) O número de populações envolvidas - Apenas uma ou mais de uma.

iii) A quantidade de traços latentes - Apenas um ou mais de um.

No ENEM, a natureza do item é dicotômica, ou seja, certo ou errado; apenas uma população está envolvida e queremos medir apenas um traço latente.

\subsubsection{Métrica do item}

Para esta medida utilizamos uma escala estabelecida pelo INEP a partir do exame de 2009, onde foi estabelecido que, 500 seria o valor de posição ou de referência, 
este valor representa o desempenho médio dos concluintes do Ensino Médio da rede pública de 2009 que realizaram o exame naquele ano. Atribuíram também 100 para o valor de dispersão, que seria a medida de variabilidade média das notas daqueles concluintes em relação ao valor de referência.

Esta métrica, portanto, garante que um aluno com nota 700 está a duas unidades de desvio padrão acima da proficiência média dos concluintes de 2009. Graficamente representaríamos uma régua conforme o gráfico abaixo apresentado na página do INEP.

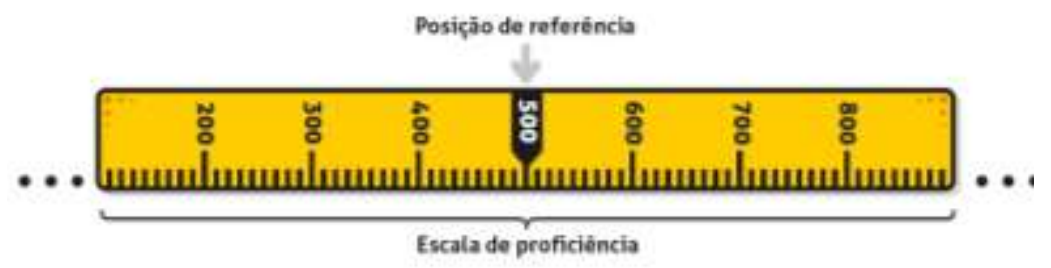

Figura 1 - Escala de proficiência

Segundo o INEP

\begin{abstract}
A sua nota na escala (régua) pode assumir qualquer valor no conjunto dos números reais, como, por exemplo, $632,6,421,8$, etc. Outro aspecto importante no cálculo da nota é que as notas mínima (nenhum acerto) e máxima (45 acertos) dependem do grau de dificuldade da prova. Como já comentado, a prova é constituída por um conjunto de itens com parâmetros previamente conhecidos. São esses parâmetros que definem os valores de mínimo e máximo da prova. Assim, quando a prova é composta com muitos itens fáceis, o máximo da prova tenderá a ser mais baixo, e quando ela é composta com muitos itens difíceis, o mínimo tenderá a ser mais alto. Então, está claro que a nota mínima não é " 0 " e a nota máxima não é 1.000. (Fonte: Página do INEP .(7) )
\end{abstract}

Na Teoria Clássica do Teste (TCT), o importante é a prova na sua totalidade, ou seja, o aluno é classificado de acordo com o seu número de acertos, portanto, o aluno fica sujeito às intempéries do exame, isto é, um exame muito difícil, com notas muito baixas, leva à conclusão de que os alunos dominam pouco àquele conteúdo, em contrapartida, se a prova é muito fácil, pode de uma forma leviana levar à conclusão que os alunos são muito acima da média.

$\mathrm{Na}$ TRI o foco passa a ser o item, que deve avaliar apenas uma habilidade, que é construído atendendo a critérios estabelecidos pelo INEP, como:

i) Operação Cognitiva - que ações são requeridas para o examinando resolver a situação problema. 
ii) Objetos do Conhecimento - O que o respondente deve dominar em termos de conhecimentos para executar a Operação Cognitiva.

iii) Contextualização - Dá a oportunidade ao respondente de fazer a ligação entre o que se aprende na escola e o cotidiano. Permite que aplique seu conhecimento acumulado e a partir de operações mentais resolva as situações envolvidas no item.

Na elaboração dos itens são considerados contextos relacionados a cada área do conhecimento que possam estabelecer relações entre problemas que se apresentem no cotidiano e os conhecimentos acumulados na sua experiência escolar.

\subsubsection{Correção}

Dentre os modelos propostos na correção do item pela TRI, utiliza-se o modelo logístico de 3 parâmetros (ML3) que leva em conta a proficiência do examinando $(\theta)$, e os parâmetros ligados ao item, tais como, discriminação do item(a), dificuldade do item(b) e a resposta ao acaso(c). Um dos programas utilizados para corrigir estes exames é o Bilog- MG (Rabelo)

De acordo com Andrade, cada item, portanto, é corrigido e retorna como uma curva denominada Curva Característica do Item (CCI) e a cada respondente é atribuído um valor na Função Resposta do Item (FRI):

$$
P\left(U_{i j}=1 \mid \theta_{j}\right)=c_{i}+\left(1-c_{i}\right) \frac{1}{1+e^{-D a_{i}\left(\theta_{j}-b_{i}\right)}}
$$

$\mathrm{P}\left(\mathrm{U}_{\mathrm{j}}=1 \mid \theta_{\mathrm{j}}\right)$ é a probabilidade de um indivíduo j com habilidade $\theta_{\mathrm{j}}$ responder corretamente o item i e é chamada de Função de Resposta do Item - FRI.

Uij é uma variável dicotômica que assume valores 1 , quando o indivíduo $\mathrm{j}$ responde corretamente o item $\mathrm{i}$, ou 0 quando o indivíduo $\mathrm{j}$ não responde corretamente o item $\mathrm{i}$.

$\theta \mathrm{j}$ representa a habilidade (traço latente) do j-ésimo indivíduo.

$b_{i}$ é o parâmetro de dificuldade do item i, medido na mesma escala da habilidade.

$\mathrm{a}_{\mathrm{i}}$ é o parâmetro de discriminação do item $\mathrm{i}$, com valor proporcional à inclinação da Curva Característica do Item - CCI no ponto $b_{i}$.

$\mathrm{c}_{\mathrm{i}}$ é o parâmetro do item que representa a probabilidade de indivíduos com baixa habilidade responderem corretamente o item $\mathrm{i}$. 
D é um fator de escala, constante e igual a 1. Utiliza-se o valor 1,7 quando se deseja que a função logística forneça resultado semelhante ao da função ogiva normal.

$\mathrm{Na}$ figura 2, retirada da página do INEP, os parâmetros $\mathrm{a}, \mathrm{b}$ e c estão representados, bem como um participante A. Por exemplo, este participante com proficiência 650, apresenta aproximadamente $85 \%$ de chance de responder corretamente a questão. O esperado é que 85 \% dos participantes com proficiência 650 acertem este item.

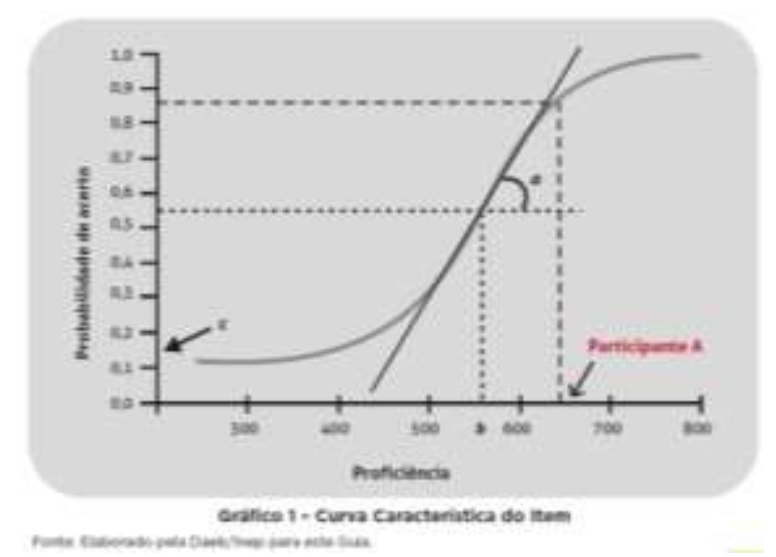

Figura 2 - Curva de característica do item

$\mathrm{Na}$ TRI, mais que estimar as dificuldades dos itens e as proficiências dos participantes, essa metodologia permite que os itens de diferentes edições do exame sejam posicionadas em uma mesma escala, que é uma métrica ou uma régua. Uma vez realizado este posicionamento na régua, a interpretação das características pedagógicas do item pode contribuir para uma análise qualitativa das habilidades que os participantes já dominam e daquelas cujo domínio eles ainda estão construindo. Cada uma das quatro áreas do conhecimento avaliadas pelo ENEM possui uma escala própria, uma vez que avalia constructos distintos, quais sejam, a proficiência em: Linguagens, Códigos e suas Tecnologias; Matemática e suas Tecnologias; Ciências da natureza e suas tecnologias; e Ciências Humanas e suas Tecnologias. A interpretação pedagógica destas escalas é importante pra ampliar a compreensão do significado das proficiências dos parâmetros 
de dificuldades dos itens, na medida em que busca oferecer um sentido qualitativo e pedagógico às estimativas quantitativas. (Fonte: Página do INEP, (7))

A figura 3, também apresentada na página do ENEM (7), mostra dois participantes A e B posicionados na régua. Observe que o participante A, que apresenta uma proficiência em torno de 650, tem grande probabilidade de responder os itens 1, 34, 45, 12 e 16. Da mesma forma espera-se do participante B, com proficiência em torno de 400 , que apresente conhecimento suficiente para responder com sucesso os itens 1 e 34. Espera-se que o participante A tenha dificuldade para responder corretamente os itens 19 e 35, e o participante B os itens $45,12,16,19$ e 35 . O exame tem caráter probabilístico, portanto, não se pode afirmar que o participante $\mathrm{B}$, por exemplo, não acertará o item 35 .

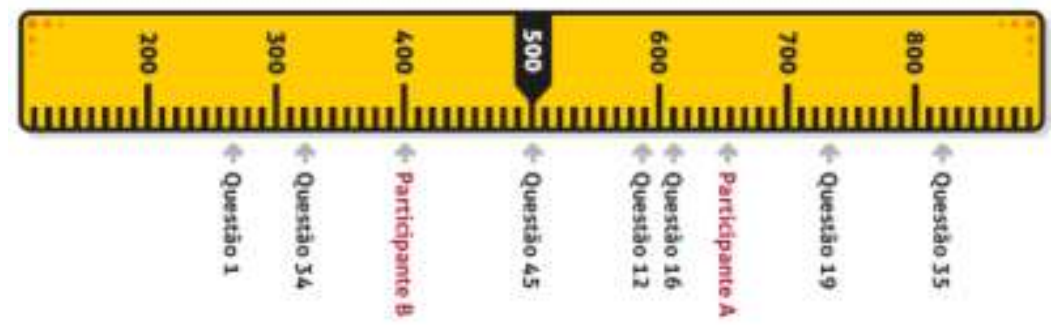

NOTA: A escala tem uma interpretaçáo pedagógica, e as questóes são posicionadas na régua (escala) de acordo com uma coeréncia pedagógica o participante também será posicianado na régua, ou seja. terá sua nota conforme seu conhecimento pedagógico. 1 sso quer dizer que sua nota nâo depende das notas dos demais participantes. mas apenas do posicionamento das questóes na régua.

Figura 3 - Posicionamento na métrica do ENEM de 2 alunos

Uma característica da TRI é ter o índice de dificuldade (b) e a proficiência do participante $(\theta$ na mesma escala.

Segundo os critérios do ENEM, espera-se que alguém com determinada proficiência $\theta$ possa resolver questões cujos índices de dificuldade (b), sejam menores que $\theta$ Em alguns casos o examinando poderá acertar itens mais difíceis e errar itens mais fáceis, no entanto, espera-se dos candidatos uma coerência nas suas respostas, ao conjunto de respostas do candidato está associado o seu traço latente $(\theta)$. 
A TRI é um método que a partir do conjunto de respostas do candidato, determina qual proficiência maximiza a probabilidade do candidato ter dado aquele conjunto de respostas.

Cada participante responde às 45 questões de cada área de uma forma particular, ou seja, dois alunos podem acertar o mesmo número de questões, porém de formas diferentes, desta forma, terão resultados diferentes, a figura 4 apresentado na página do ENEM (7), apresenta dois alunos fíctícios, com 5 acertos cada um e notas diferenciadas, pois acertaram questões distintas.

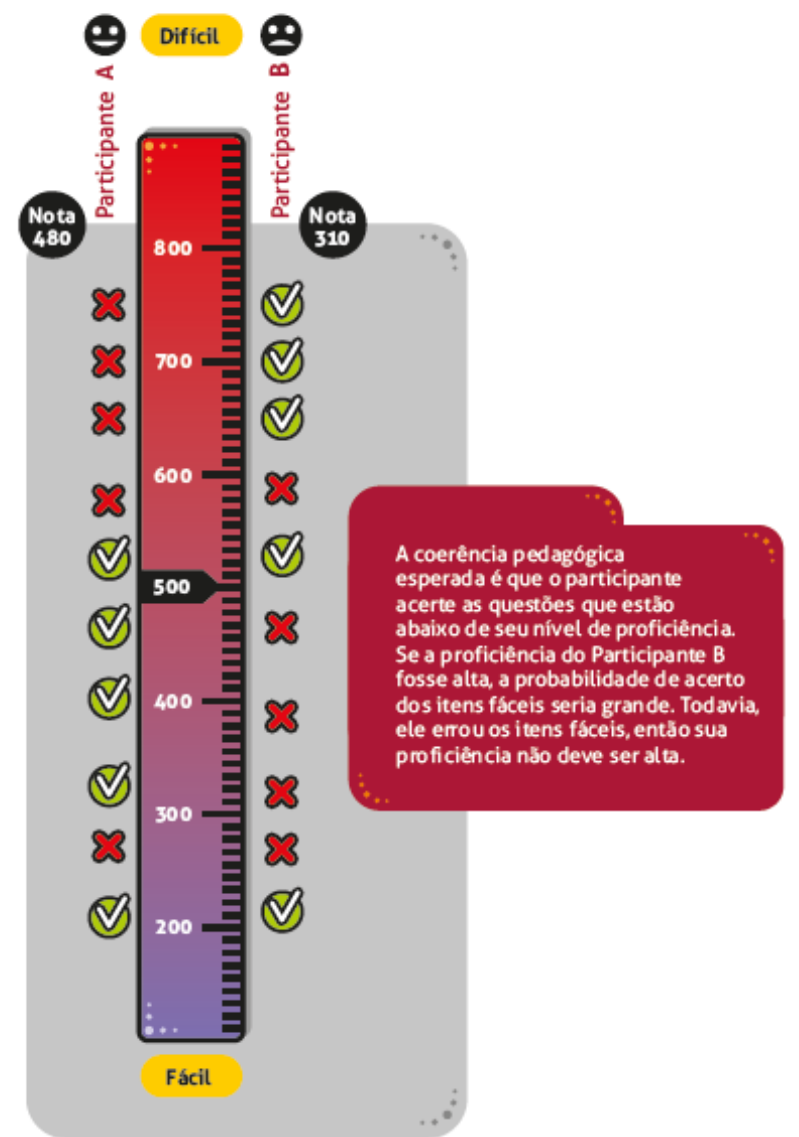

NOTA: Quando dizemos que o participante acertou uma questão "no chute", não significa que sua nota irá diminuir, mas ela não tem tanto valor como se o participante tivesse acertado os itens com a coerência pedagógica esperada. Então, sempre é melhor responder à questão do que a deixar em branco, pois uma questão certa sempre aumenta a nota, e uma questão deixada em branco é corrigida como errada.

Figura 4 - Comparativo entre dois alunos com acertos diferentes 


\section{3 Interpretação dos dados}

\subsection{Resultados divulgados pelo INEP}

O Governo tem como um dos seus objetivos ao aplicar a prova do ENEM, instrumentalizar as escolas de ensino básico no que diz respeito ao seu Projeto Pedagógico ao divulgar o resultado dos alunos de cada escola.

As escolas também esperam esta informação oficial do governo, no entanto, recebem apenas uma média, que por si só não tem significado, pois dizer que a nota do colégio em matemática é 612,34 , não significa dizer que $60 \%$ dos seus alunos dominam de forma adequada as habilidades que se apresentaram no exame, muito menos que $60 \%$ do conteúdo foram assimilados pelos alunos, afinal, nem a prova vale 1000 pontos nem a correção está ligada ao número de acertos na prova. Os diretores dos colégios esperam algo mais para que possam melhorar o rendimento de seus alunos.

Para a sociedade estes resultados são percebidos de maneiras distintas. Algumas famílias querem saber o resultado para terem certeza de que seus filhos estão matriculados em um colégio bom, outras esperam a divulgação oficial para matricularem os seus filhos no colégio que apresentar a maior nota na sua cidade, logo, esta nota parece ter um significado diferente do percebido pela comunidade escolar.

A imprensa também se mobiliza para insuflar esta dialética entre a sociedade e as escolas, divulgando rankings, como em 2013, que levaram em conta apenas os resultados das quatro áreas de conhecimento, justificando que estas são mensuráveis e comparáveis, pois foram corrigidas pela TRI, e logo em seguida divulga um outro ranking agregando o resultado da redação, afinal tradicionalmente a redação era incluída desde 1998. Este fato também é bastante interessante, pois desde esta época já havia comparações entre as escolas, porém, como só a partir de 2009, a nota do ENEM passou a servir como ingresso parcialmente ou exclusivamente para as universidades públicas, a competição 
entre as escolas de cada cidade ou estado ficou acirrada, já que agora a sociedade também participa desta polêmica.

Algumas escolas assumiram uma postura agressiva, visando um possível resultado de ponta neste exame, afinal toda a imprensa dá cobertura em tempo integral às escolas que integram os primeiros lugares. Pensando em termos de mercado esta é uma excelente oportunidade de mostrar os seus resultados.

Existem, no entanto, escolas que assumem um formato pedagógico em que o aluno é trabalhado de forma mais ampla, individualizada, onde conta muito o seu crescimento pessoal, onde o seu lugar no grupo é tão importante quanto o crescimento do grupo. Estas escolas percebem alguns de seus alunos de forma diferente, pois acreditam que tratar diferente os diferentes é dar igual oportunidade de crescimento aos indivíduos desta sociedade tão heterogênea, neste momento de exposição na imprensa, estas escolas que podem acrescentar muito aos alunos nem sempre são entendidas pela comunidade escolar da maneira como deveriam ser.

O INEP divulga em seu site os dados individuais dos alunos que participaram do exame sem identifica-los, no entanto, o formato ainda é inacessível às escolas, afinal é necessário tecnologia de ponta para se obter os dados e profissional que conheça linguagem avançada para dividir em partes menores os arquivos, por isso, apesar dos microdados estarem à disposição é irrelevante a parcela da comunidade escolar que consegue esses dados, que tem instrumentos estatísticos para tratá-los da melhor forma e ainda dividir com os coordenadores, professores e alunos, este conhecimento que, com certeza, terá uma utilidade fundamental para traçar estratégias visando aumentar o rendimento dos alunos que última análise é uma das metas deste trabalho que é contribuir de forma efetiva para a melhoria acadêmica dos alunos e da educação de modo geral.

\subsection{Resultados obtidos nos microdados do ENEM 2012}

No site do INEP estão os dados dos exames desde 1998. Este trabalho de conclusão de curso tem como foco conhecer os dados no ENEM 2012 dos alunos do Estado do Rio de janeiro, parcela significativa dos examinandos, tanto em número de candidatos quanto em escores. Em particular, é de extremo interesse, obter os dados dos alunos do Colégio Israelita Brasileiro A. Liessin, onde 
coordeno a terceira série do Ensino Médio, mas que pode ser feito por qualquer escola, basta para isso utilizar o número do estabelecimento no Educacenso.

Inicialmente a busca realizada tinha o objetivo de reunir os dados das provas dos alunos que estão terminando o ensino básico no referido colégio, afinal, como foi mencionado anteriormente, conhecer em cada área do conhecimento: o desempenho de cada aluno; as questões que foram acertadas; como reagiram os alunos frente às habilidades que foram apresentadas nas provas; como foi o aproveitamento em redação e como os alunos se distribuíram em relação às suas notas, pode dar subsídios para o aprimoramento do projeto pedagógico e em consequência elevar os resultados dos examinandos nos anos posteriores.

Com esses dados em mãos podemos identificar de forma absoluta que conteúdos devem ser mais bem trabalhados, que áreas do conhecimento estamos bem ou se estamos apresentando alguma dificuldade. Relativamente, com este trabalho de conclusão, buscamos comparar nossos resultados com os alunos do Estado do Rio de Janeiro. Estes dados devem revelar muito mais que simplesmente uma média atribuída a cada escola.

Os dados foram divididos em dois segmentos, o primeiro em relação à distribuição dos alunos segundo suas notas, e, o segundo, em relação ao desempenho dos alunos em cada área, onde foi possível conhecer que habilidades os alunos do Colégio A. Liessin haviam acertado no exame.

\subsubsection{Distribuição dos alunos de acordo com as notas obtidas}

Em cada área do conhecimento, Ciências da Natureza e suas Tecnologias, Ciências Humanas e suas Tecnologias, Linguagens, Códigos e suas Tecnologias e Matemática e suas Tecnologias, os alunos do Colégio A. Liessin e os alunos do Estado do Rio de Janeiro foram distribuídos segundo suas notas no ENEM de 2012.

\subsubsection{Lista de notas dos alunos}

Segue então, a lista de notas dos 70 alunos do Colégio A. Liessin. Os alunos não são identificados pelo INEP. As notas foram assim distribuídas de acordo com as áreas de conhecimento: 
Tabela 1 - Notas dos alunos do Colégio A. Liessin no ENEM 2012

\begin{tabular}{|c|c|c|c|c|}
\hline $\begin{array}{c}\text { Ciências } \\
\text { da } \\
\text { Natureza }\end{array}$ & Ciências & $\begin{array}{c}\text { Linguagens } \\
\text { e } \\
\text { Códigos }\end{array}$ & Matemática & Redação \\
\hline 582,2 & 652,5 & 606,3 & 670,3 & 700 \\
\hline 594,6 & 490,5 & 540,2 & 674,4 & 500 \\
\hline 651,5 & 711,3 & 571,7 & 803,1 & 920 \\
\hline 653,8 & 653,6 & 677,1 & 722,2 & 780 \\
\hline 602,5 & 615,0 & 621,8 & 717,1 & 460 \\
\hline 676,5 & 696,8 & 689,1 & 765,5 & 640 \\
\hline 653,8 & 668,5 & 607,6 & 849,9 & 880 \\
\hline 656,5 & 751,8 & 603,3 & 718,8 & 680 \\
\hline 701,3 & 699,8 & 651,3 & 831,1 & 940 \\
\hline 634,8 & 639,9 & 567,6 & 798 & 660 \\
\hline 586,1 & 587,1 & 512,9 & 635,9 & 620 \\
\hline 573,0 & 655,4 & 547,3 & 636,6 & 560 \\
\hline 557,7 & 606,0 & 609,0 & 685,9 & 640 \\
\hline 571,1 & 548,8 & 585,4 & 772 & 620 \\
\hline 632,5 & 631,7 & 605,6 & 738 & 480 \\
\hline 436,3 & 564,5 & 533,2 & 602,7 & 980 \\
\hline 581,5 & 658,3 & 631,4 & 721,8 & 780 \\
\hline 679,6 & 708,6 & 653,8 & 804,9 & 860 \\
\hline 507,0 & 658,7 & 594,2 & 662,7 & 860 \\
\hline 430,6 & 588,3 & 583,3 & 594,3 & 420 \\
\hline 530,7 & 614,9 & 573,1 & 661,3 & 840 \\
\hline 567,2 & 648,9 & 643,1 & 683,5 & 640 \\
\hline 602,3 & 723,6 & 643,2 & 751,2 & 720 \\
\hline 579,3 & 608,0 & 581,0 & 670,3 & 680 \\
\hline 714,4 & 682,0 & 660,4 & 866,2 & 500 \\
\hline 661,7 & 609,4 & 554,6 & 816,9 & 800 \\
\hline 569,6 & 592,7 & 567,7 & 696,3 & 580 \\
\hline 601,0 & 558,9 & 517,4 & 751,1 & 620 \\
\hline 693,1 & 674,3 & 598,1 & 837,1 & 840 \\
\hline 585,4 & 622,6 & 504,4 & 672,5 & 380 \\
\hline 518,8 & 615,6 & 559,5 & 649,3 & 780 \\
\hline 528,4 & 625,6 & 600,6 & 676,2 & 660 \\
\hline 692,6 & 661,9 & 599,3 & 861,1 & 520 \\
\hline 666,2 & 655,1 & 568,5 & 776,4 & 660 \\
\hline 653,1 & 708,7 & 682,4 & 740,1 & 920 \\
\hline 609,3 & 660,7 & 596,2 & 726,3 & 860 \\
\hline 691,6 & 796,9 & 647,2 & 837,4 & 760 \\
\hline 634,8 & 602,4 & 596,2 & 843,5 & 740 \\
\hline 679,7 & 679,6 & 585,7 & 827,2 & 1000 \\
\hline
\end{tabular}




\begin{tabular}{|c|c|c|c|c|}
\hline 595,9 & 662,9 & 623,5 & 787,4 & 980 \\
\hline 675,0 & 630,3 & 613,1 & 901,9 & 720 \\
\hline 632,6 & 653,2 & 611,3 & 708,8 & 520 \\
\hline 517,6 & 613,7 & 594,7 & 665,3 & 680 \\
\hline 463,0 & 527,3 & 503,3 & 571,9 & 440 \\
\hline 641,4 & 621,0 & 617,5 & 796,1 & 860 \\
\hline 602,1 & 645,0 & 534,9 & 766,4 & 620 \\
\hline 635,8 & 714,9 & 596,5 & 815,2 & 700 \\
\hline 508,0 & 549,2 & 495,3 & 603,4 & 500 \\
\hline 575,9 & 661,3 & 616,4 & 748,4 & 660 \\
\hline 647,0 & 672,7 & 618,6 & 836,3 & 800 \\
\hline 465,7 & 506,8 & 563,1 & 595,5 & 760 \\
\hline 572,6 & 669,8 & 585,5 & 806,9 & 960 \\
\hline$\overline{560,6}$ & 622,3 & 582,2 & 539 & 620 \\
\hline 488,0 & 603,9 & 565,4 & 629,4 & 680 \\
\hline 546,8 & 502,6 & 492,8 & 601,1 & 500 \\
\hline 591,0 & 619,1 & 549,7 & 786,3 & 740 \\
\hline 685,0 & 700,8 & 603,8 & 799,1 & 840 \\
\hline 707,8 & 732,2 & 605,8 & 869,6 & 780 \\
\hline$\overline{548,0}$ & 623,4 & 597,8 & 724,1 & 760 \\
\hline 542,0 & 619,8 & 558,4 & 791,1 & 680 \\
\hline 589,2 & 618,6 & 564,6 & 467,5 & 720 \\
\hline 675,5 & 707,1 & 670,9 & 794,6 & 760 \\
\hline 657,0 & 686,2 & 644,8 & 703,9 & 920 \\
\hline 646,5 & 594,9 & 558,0 & 919,6 & 640 \\
\hline 631,1 & 717,7 & 660,8 & 717,8 & 660 \\
\hline 564,2 & 575,5 & 528,5 & 719,2 & 600 \\
\hline 522,7 & 555,9 & 529,8 & 682,9 & 600 \\
\hline 651,2 & 630,4 & 585,9 & 692,6 & 820 \\
\hline 624,7 & 594,7 & 537,8 & 774,6 & 940 \\
\hline 692,8 & 663,4 & 618,6 & 736,4 & 800 \\
\hline
\end{tabular}

\subsubsection{Gráficos comparativos}

A ideia mais uma vez é a de estimular coordenadores das escolas de Ensino Médio a obter os dados de suas escolas. Afinal os dados de cada escola são individuais e devem ser pesquisado pelos coordenadores, mas, os dados do Rio de Janeiro já estão dispostos neste capítulo. A partir destas notas é possível construir e analisar gráficos, percebendo se a distribuição é uma curva normal, se a média foi a esperada, se existem pontos fora da curva, se esses pontos são alunos de 
excelente rendimento ou de baixo rendimento, e quais estratégias devem ser usadas para que o rendimento médio seja elevado.

Os gráficos a seguir comparam as performances, tanto dos alunos do Colégio A. Liessin, quanto dos alunos do Rio de Janeiro nas 5 áreas de conhecimento

A figura 5 exibe estes dados. Neste caso observamos que a média do Colégio está acima da média dos alunos do Rio de Janeiro em todas as áreas.

\section{Comparativo entre a Maior, a Menor e a Média das notas}

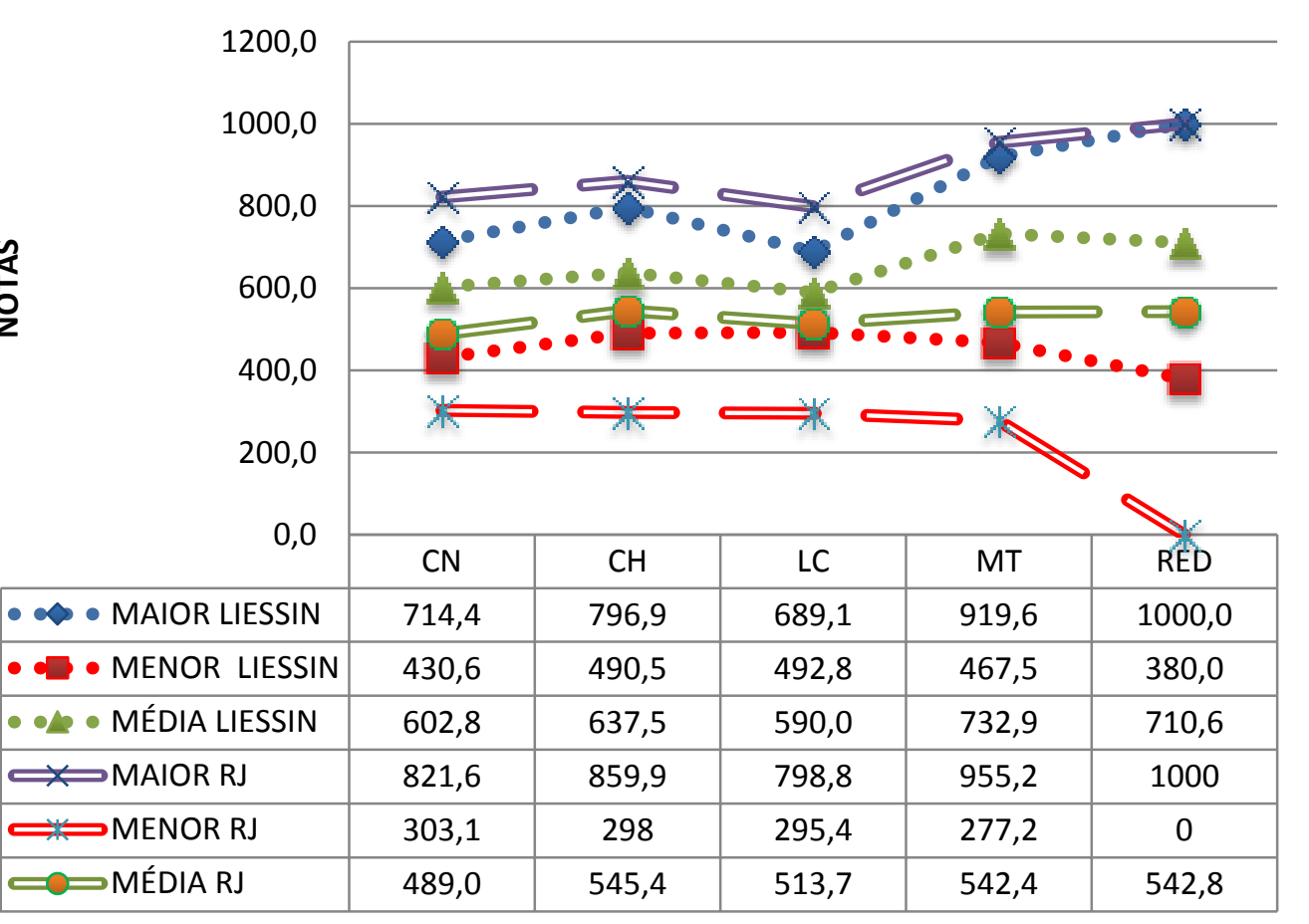

Figura 5 - Comparativo entre as notas dos alunos do colégio A. Liessin e dos participantes do Rio de Janeiro.

A comparação entre cada dupla de gráficos é bastante interessante, pois, no Rio de Janeiro está concentrado um grupo de alunos bastante significativo em relação ao total de alunos brasileiros, logo comparar com os alunos do Rio é relevante e o tamanho do arquivo é bem menor o que torna o trabalho possível para qualquer profissional que tenha instrumentos adequados. 


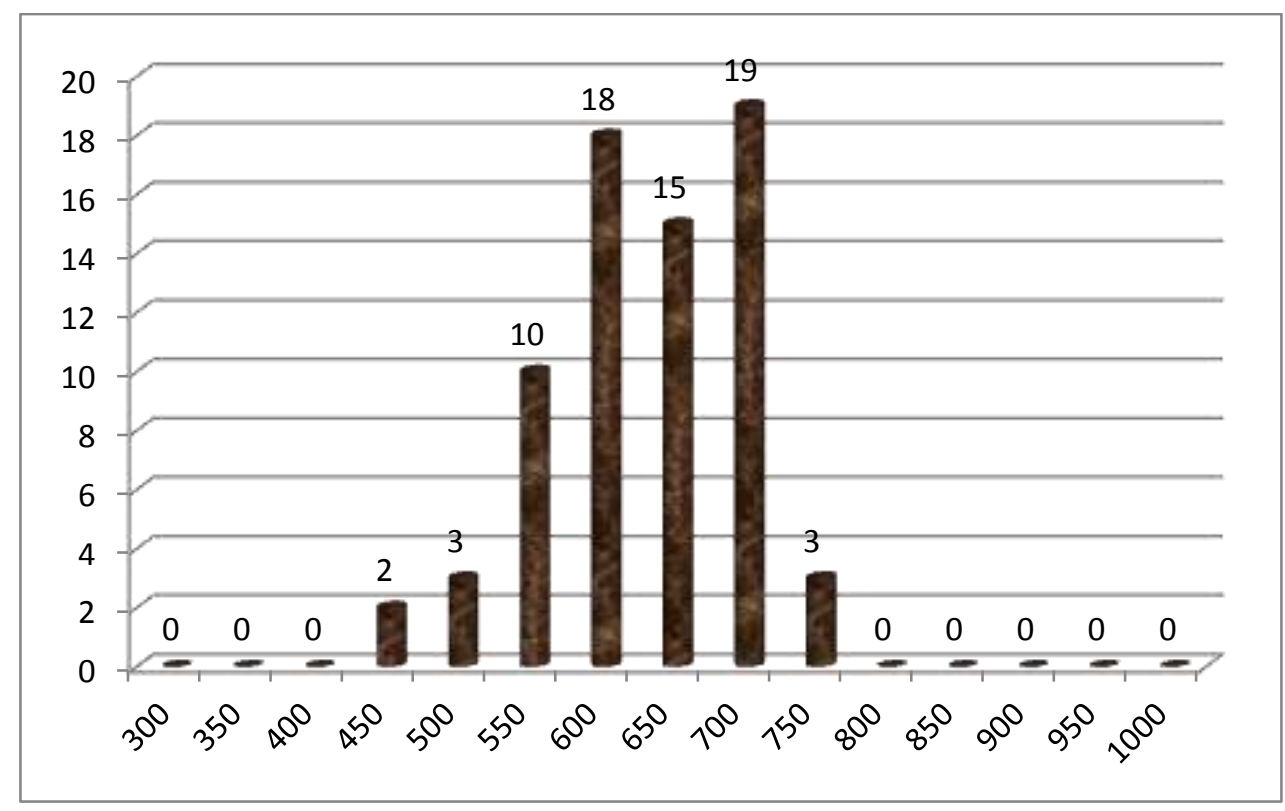

Figura 6 - Ciências da Natureza - Alunos do Colégio A. Liessin

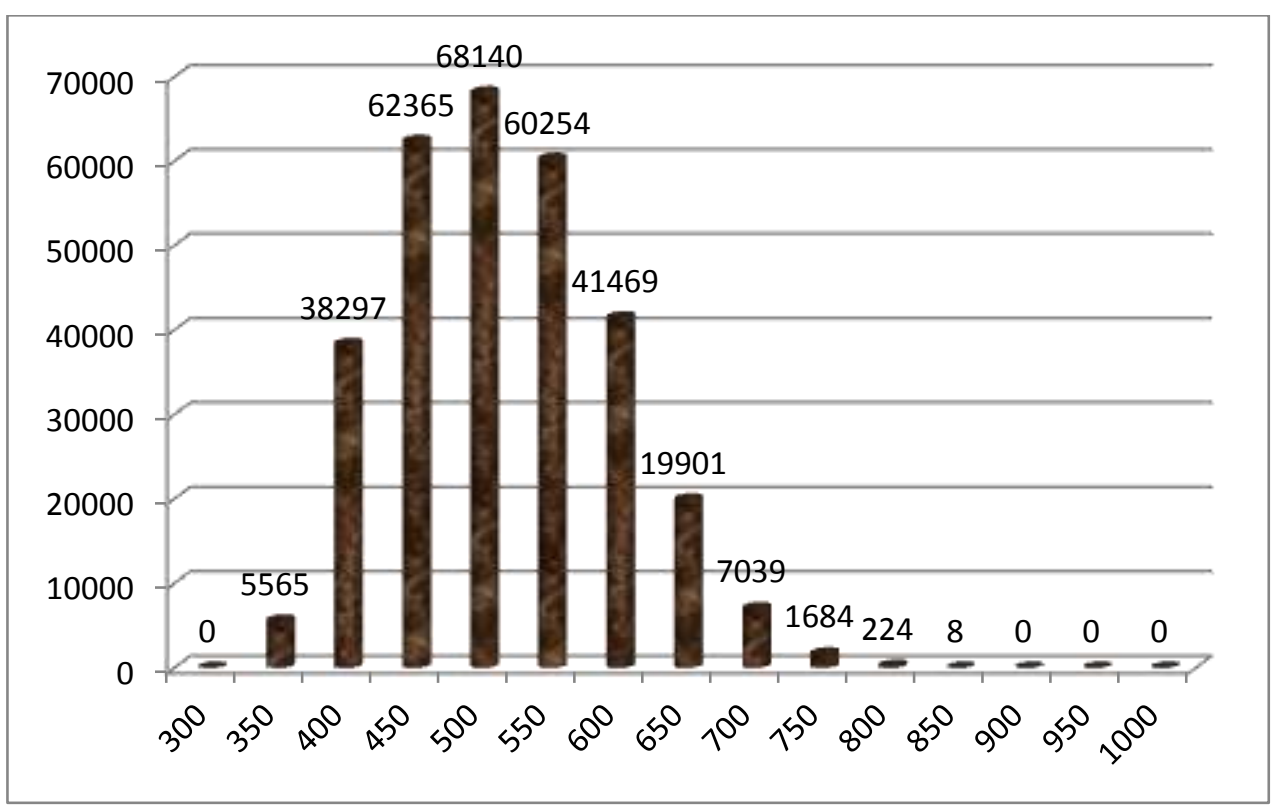

Figura 7 - Ciências da Natureza - Participantes do Rio de Janeiro

Os alunos do Colégio A. Liessin estão bem distribuídos, a nota máxima foi 714,4 , e média 602,8 , bem maior que a média do RJ, 489. Em comparação com o gráfico da figura 7 o gráfico da figura 6 apresenta o grupo de alunos alocados mais à direita que o grupo dos alunos do Rio de Janeiro, apresentando o primeiro uma proficiência maior que o segundo. 


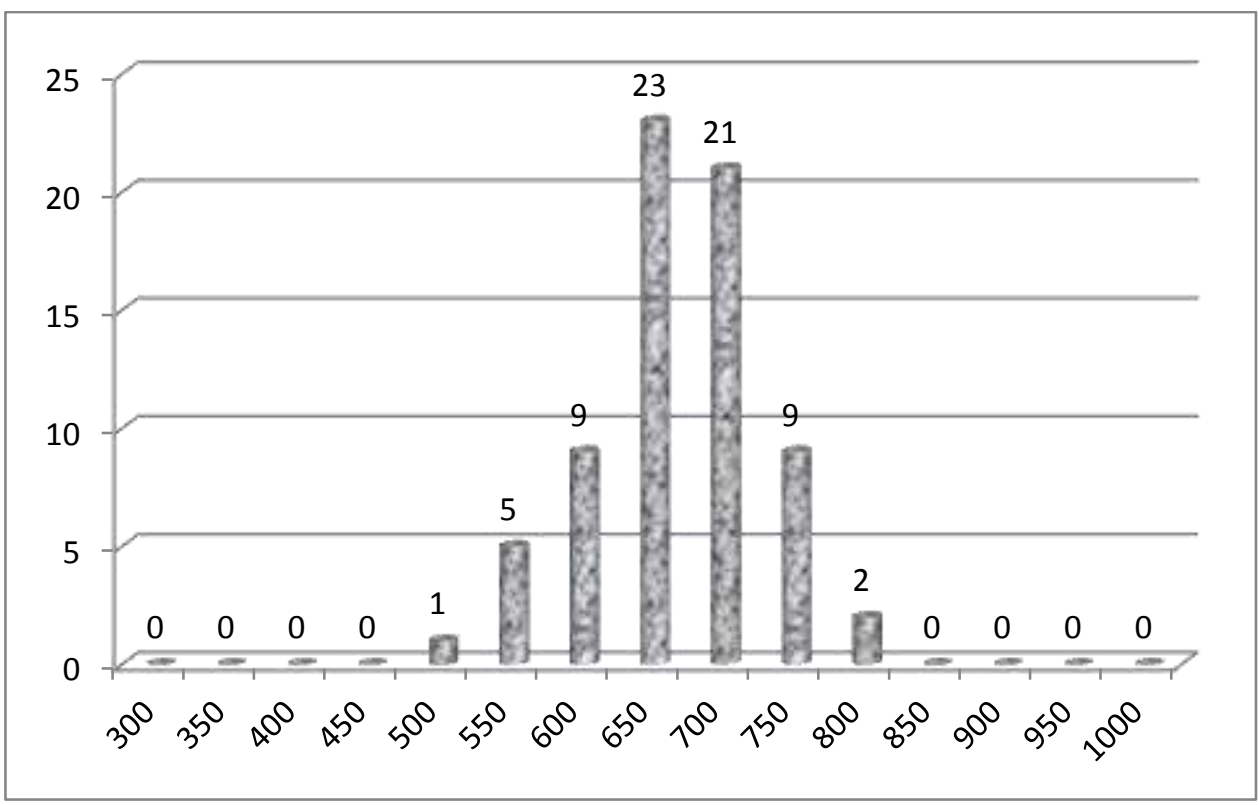

Figura 8 - Ciências Humanas - Alunos do Colégio A. Liessin

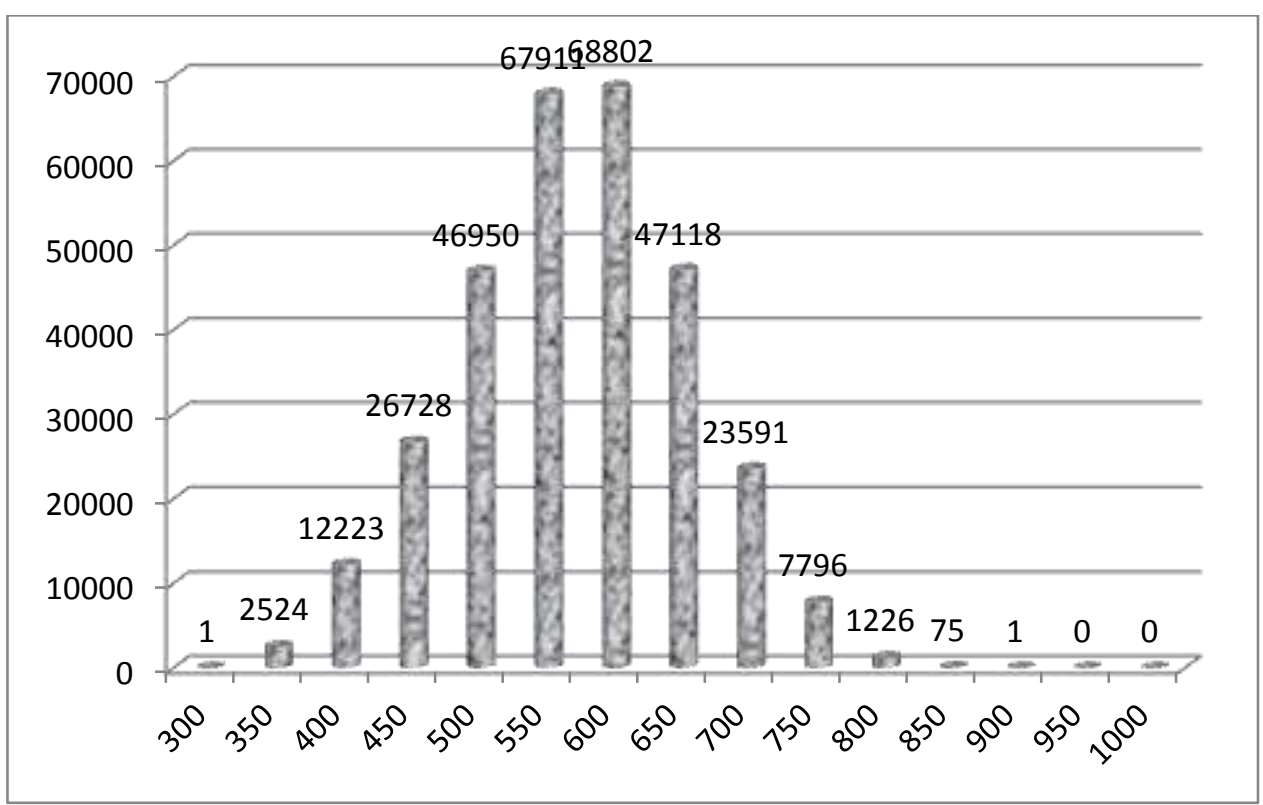

Figura 9 - Ciências Humanas - Participantes do Rio de Janeiro

O gráfico da figura 8 revela que os alunos também estão bem distribuídos, a nota máxima foi 796,9, e média 637,5, da mesma forma, acima da média do RJ, 490,5. Em comparação com o gráfico da figura 9, observamos que também nesta área os alunos do Colégio em questão teve um resultado melhor que a média do Rio de Janeiro. 


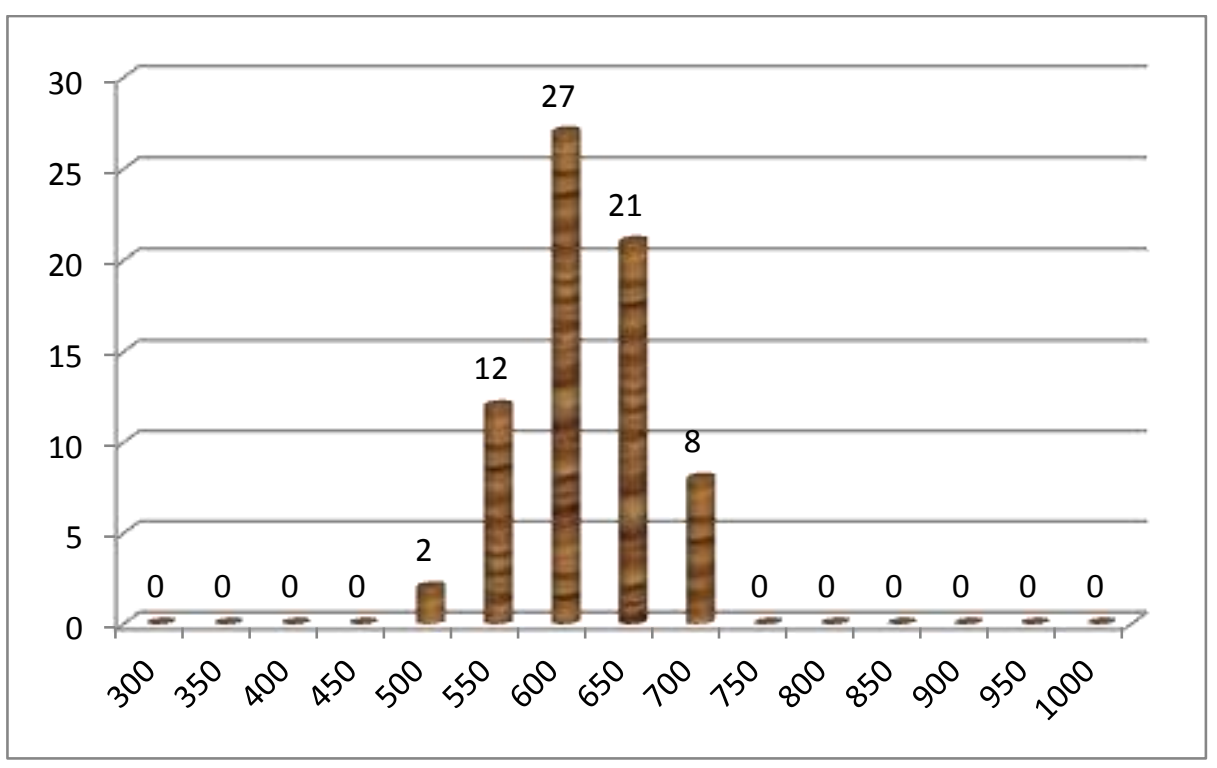

Figura 10 - Linguagem e Códigos - Alunos do Colégio A. Liessin

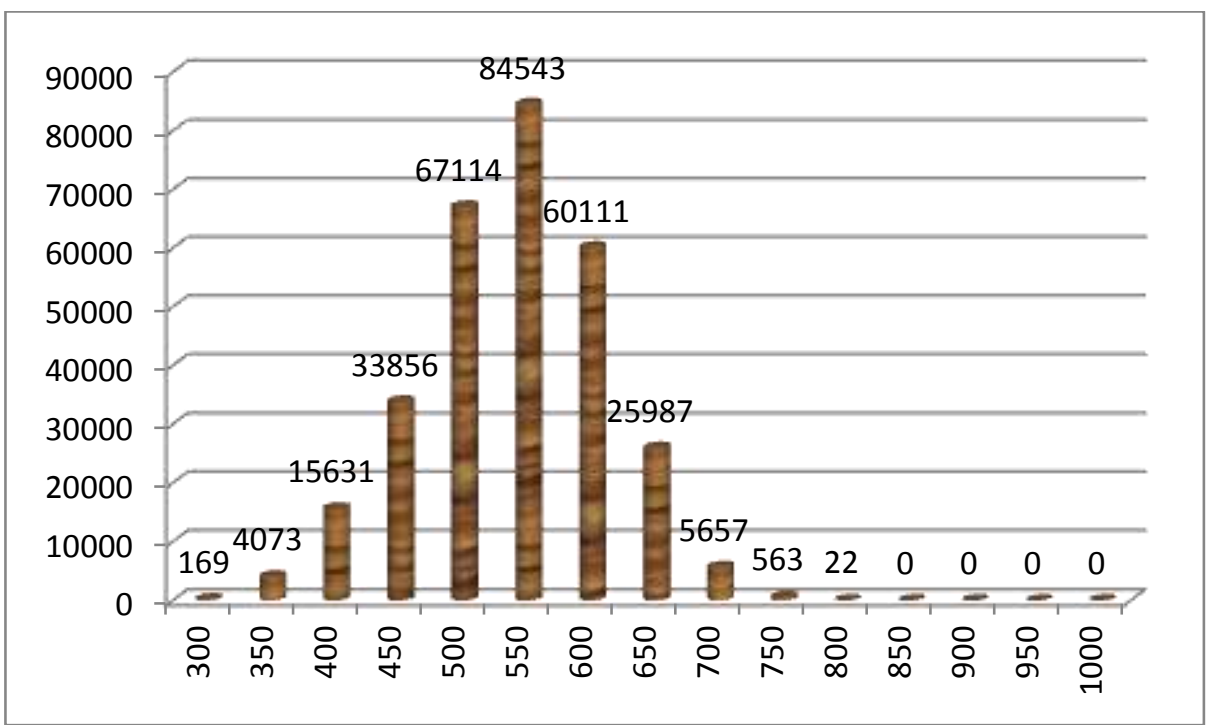

Figura 11 - Linguagens e Códigos - Participantes do Rio de Janeiro

A média em Linguagens e Códigos, 590, foi muito próxima da média do RJ, 513,7, e a maior nota, 689,1, foi menor do que a esperada pelos diretores do Colégio, ou seja, em Linguagens e Códigos, o Colégio deve criar estratégias para aprimorar o seu desempenho.

De modo geral, os alunos em todo o Brasil, tanto do quartil superior quanto do inferior, apresentam notas muito próximas da média, o que nos leva a concluir que os alunos apresentam um conhecimento bem semelhante. 


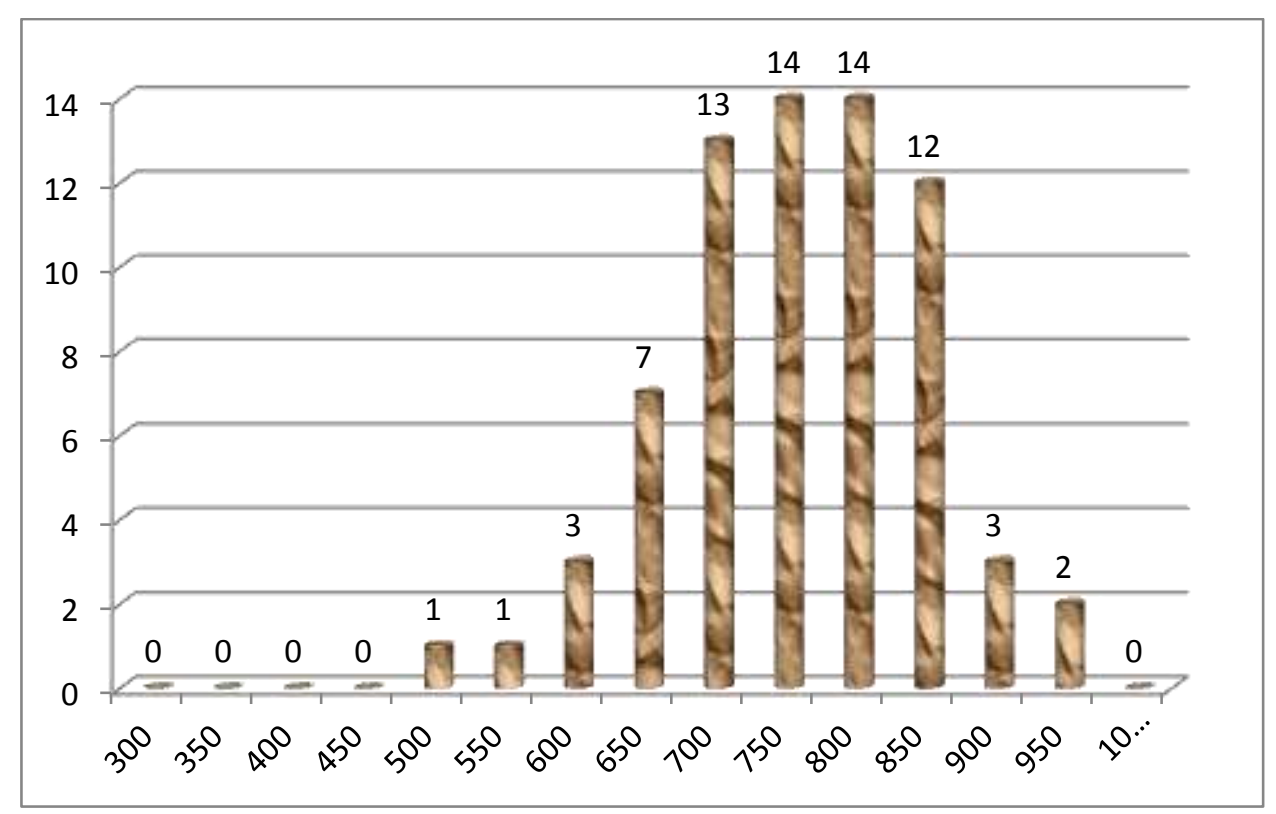

Figura 12 - Matemática - Alunos do Colégio A. Liessin

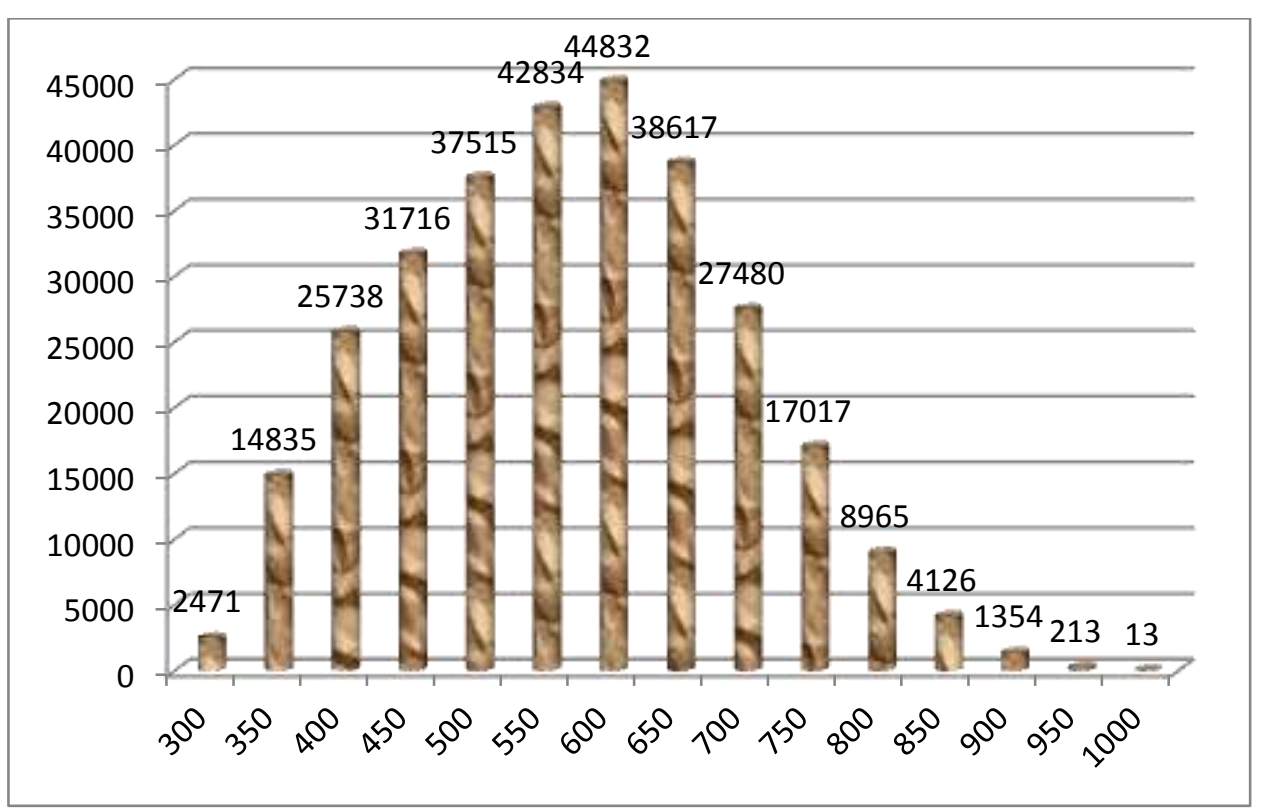

Figura 13 - Matemática - Participantes do Rio de Janeiro

Com o grupo disposto mais à direita, o que mostra alunos bem preparados $\mathrm{e}$ diferenciados do grupo do RJ. A maior nota, 919,6, foi muito próxima da maior nota do RIO e a média, 732,9, ficou muito acima da média do RJ, 542,4. Matemática foi a área na qual o Colégio A. Liessin mais se destacou. 


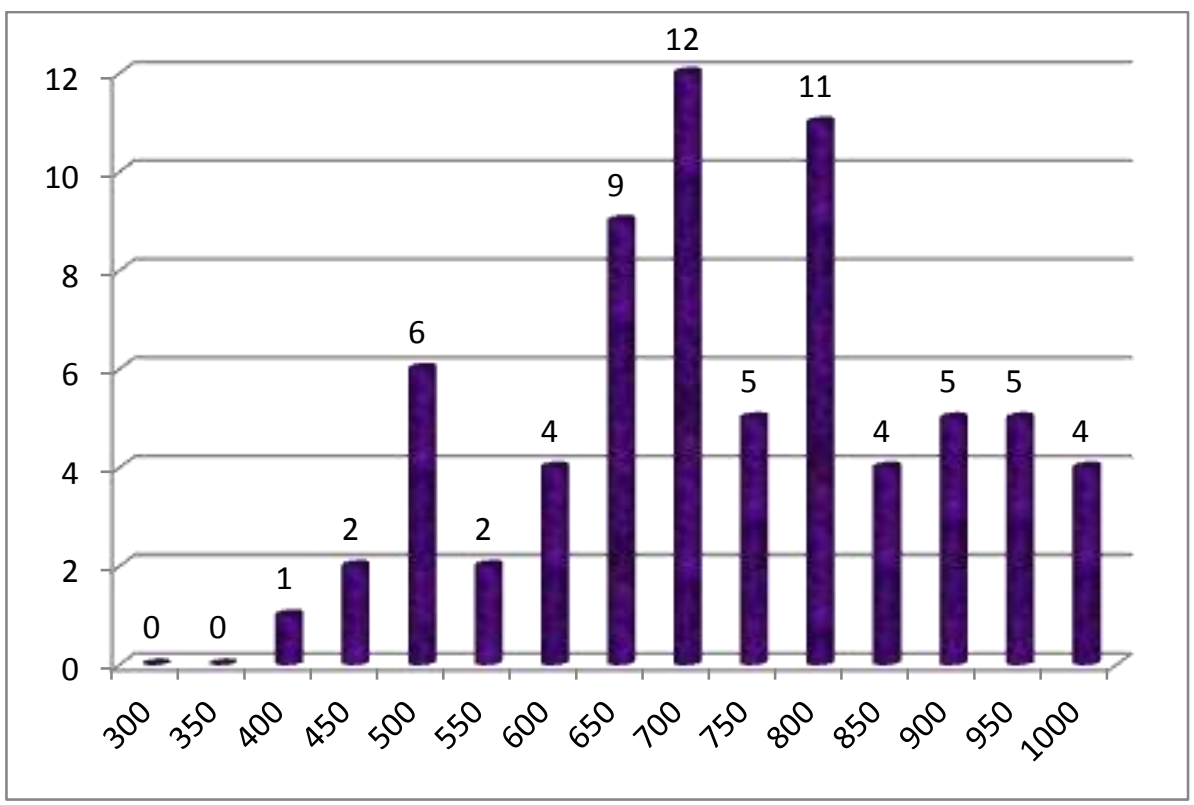

Figura 14 - Redação - Alunos do Colégio A. liessin

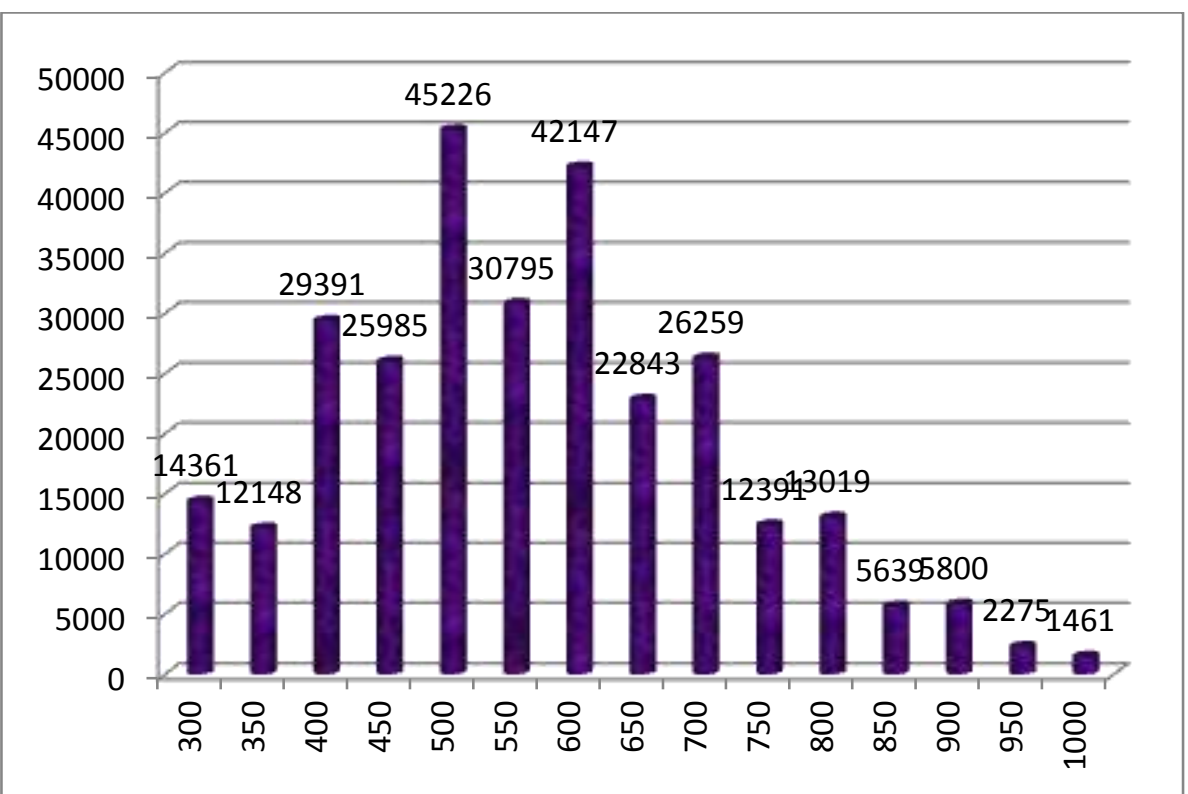

Figura 15 - Redação - Participantes do Rio de Janeiro

A distribuição dos alunos se mostrou amorfa, como os do RJ, com picos de notas, mostrando que existem alunos que produzem excelentes textos, um deles tirou nota máxima, 1000, mas, também apresenta alunos com muita dificuldade de produção textual, a menor, 380, foi uma nota muito aquém da média do Colégio, esta nota mínima diminui e muito a média do Colégio, 710,6, que ainda assim, foi muito superior à do RJ, 542,8. 


\subsubsection{Desempenhos dos alunos em cada área de conhecimento}

Nesta seção fizemos um estudo do desempenho dos alunos do Colégio A. Liessin em cada questão e em cada habilidade priorizada no exame do ENEM 2012.

\subsubsection{Gráfico de Porcentagem de acertos por questão}

Em cada área foi feito o levantamento de porcentagem de acertos em cada questão e colocado em gráfico de barras, desta forma foi possível observar que questões foram mais acertadas ou menos acertadas e assim corrigir possíveis falhas, ou até mesmo concluir que a questão era difícil e o índice de acertos ser considerado aceitável.

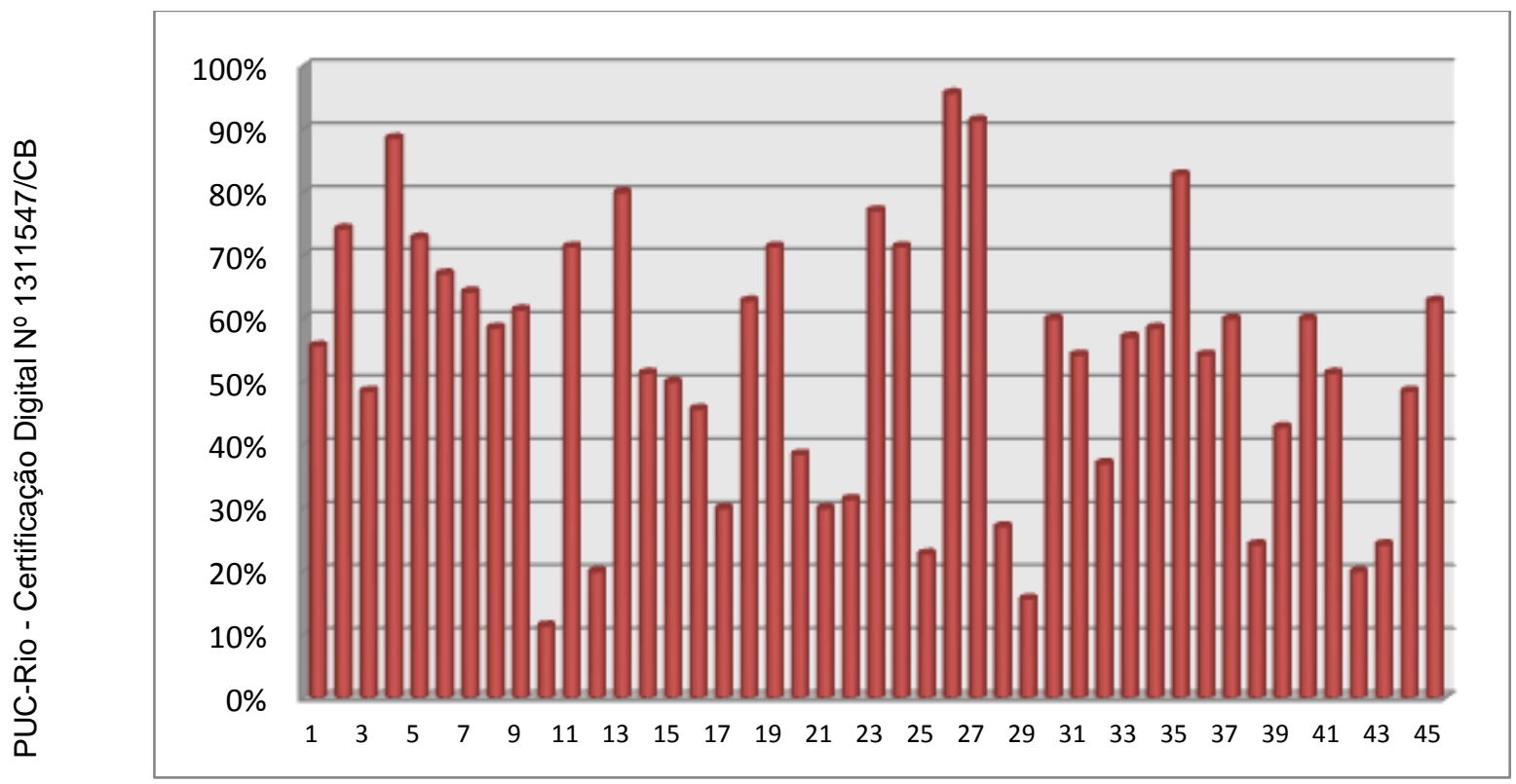

Figura 16 - Ciências da Natureza - Porcentagem de acertos por questão

Devem-se averiguar as questões 10, 12, 25, 28, 29, 38, 42 e 43 que apresentaram índice de acertos inferior a 30\%, e ainda assim comparar com os acertos levando em conta os alunos do RJ. 


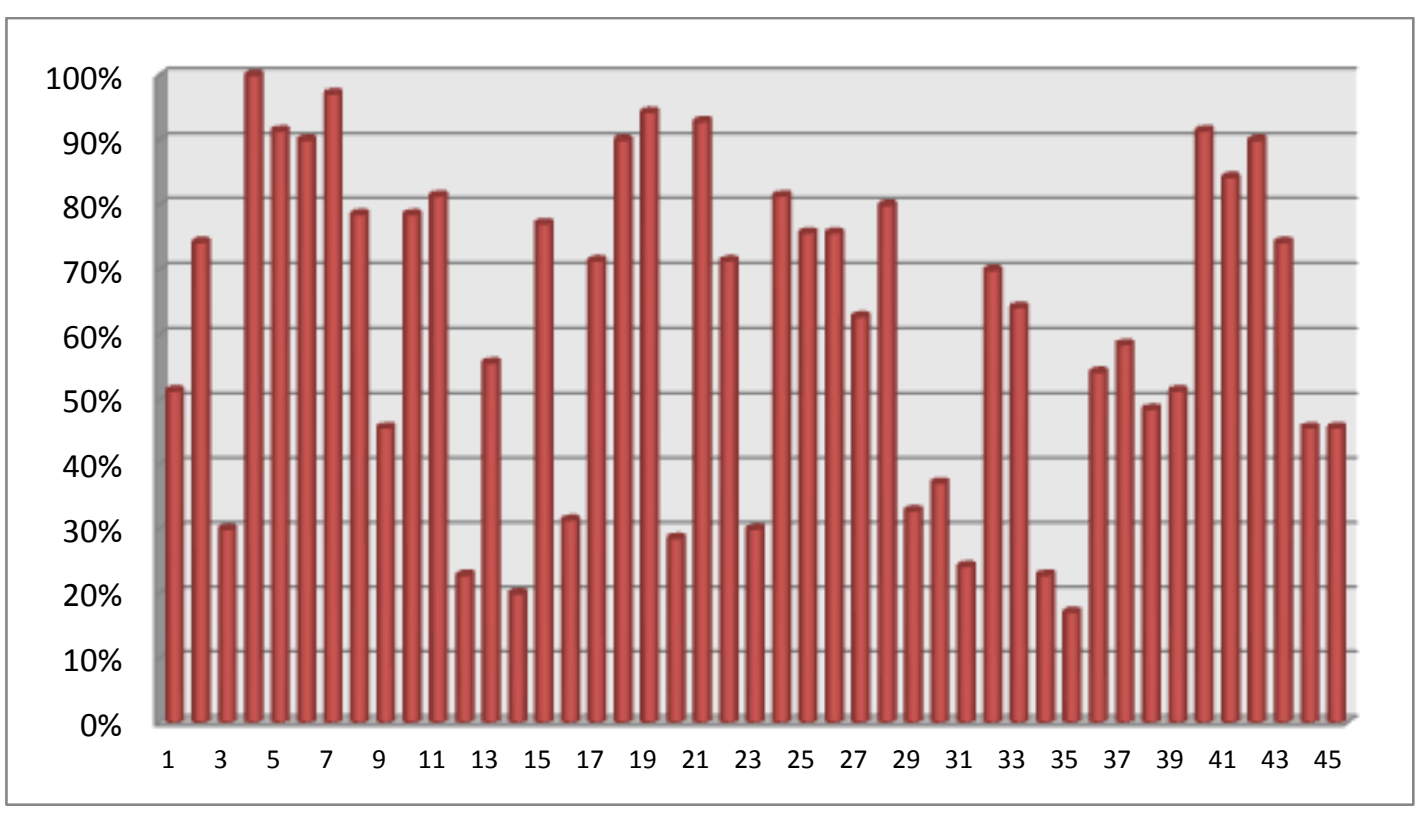

Figura 17 - Ciências Humanas - Porcentagem de acertos por questão

Devem-se averiguar aqui as questões $12,14,20,31,34$ e 35 que

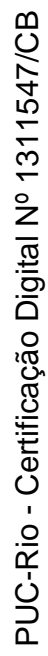
apresentaram índice de acertos inferior a 30\%, e ainda assim comparar com os acertos levando em conta os alunos do RJ.

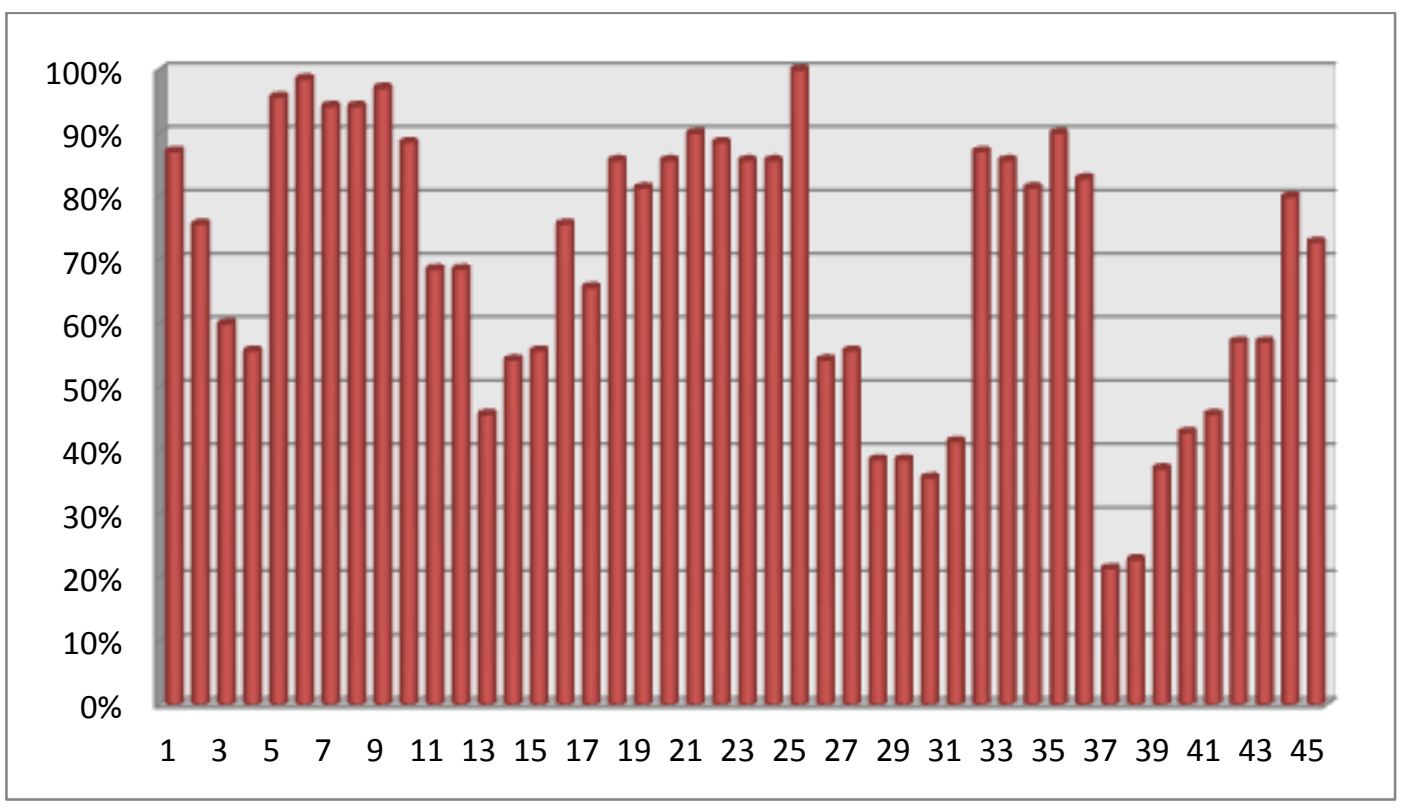

Figura 18 - Matemática - Porcentagem de acertos por questão

Apenas as questões 37 e 38 precisam ser avaliadas a princípio. 


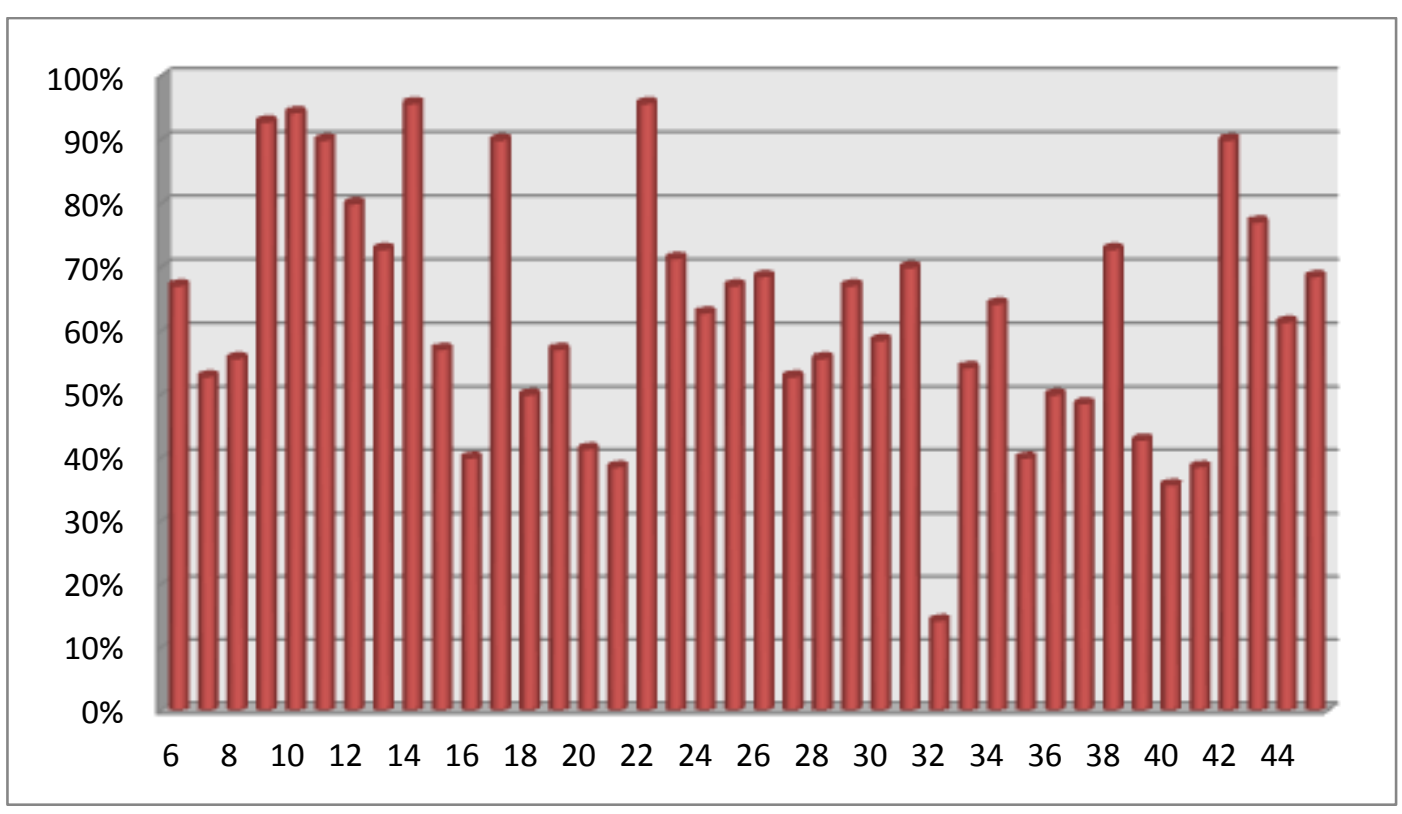

Figura 19 - Linguagens e Códigos- Porcentagem de acertos por questão

Em linguagens não foram levadas em conta as questões de língua estrangeira. Apenas a questão 32 deve ser reavaliada

\subsubsection{Gráfico de porcentagem de acertos por habilidade}

Outro gráfico interessante é o de porcentagem de acertos das habilidades, afinal um dos objetivos das questões do ENEM é o de conhecer que habilidades o examinando tem domínio. Portanto, conhecer que habilidades foram contempladas, que importância foi dada a cada uma delas pela banca examinadora, ou seja, quantas questões ligadas a uma determinada habilidade foram apresentadas no exame. Para isso propomos um gráfico de bolhas que em a seguinte característica: no eixo das abscissas estão as habilidades de cada área de conhecimento, em cada área de conhecimento são descritas 30 habilidades, espera-se que todas elas sejam contempladas; no eixo das ordenadas estão as porcentagem de acertos e o diâmetro de cada bolha é proporcional ao número de vezes em que as questões apresentaram tal habilidade. Portanto, se uma determinada habilidade foi contemplada apenas uma vez tem um determinado diâmetro, se apareceu duas vezes a bolha tem um diâmetro maior e se apareceu três vezes a medida do diâmetro é maior ainda. Em relação à porcentagem de acertos a bolha está mais acima ou mais abaixo de acordo com a relação entre a 
média de acertos das questões que contemplaram a habilidade e número de alunos do colégio.

Devemos estar atentos àquelas habilidades que acertamos menos e que apareceram mais no exame, ou seja, temos que identificar quais os itens da prova relacionados à habilidade em questão.

Por exemplo, na figura 20, referente à prova de Ciências da Natureza, a habilidade 6 só é contemplada uma vez e apenas $11 \%$ dos alunos do Colégio A. Liessin acertaram esta questão. Por sua vez a habilidade 10 apareceu em duas questões e $42 \%$ dos alunos lograram sucesso nestas questões.

A análise a ser feita deve ser a de analisar o nível de dificuldade da questão para saber se o percentual de acertos é coerente, segundo se o resultado não for o esperado criar estratégias para que a habilidade em questão seja entendida pelo grupo de alunos, de modo que o próximo grupo a fazer o ENEM atenda as exigências impostas pelo INEP.

A mesma análise deve ser feita para os gráficos das figuras 21, 22 e 23.

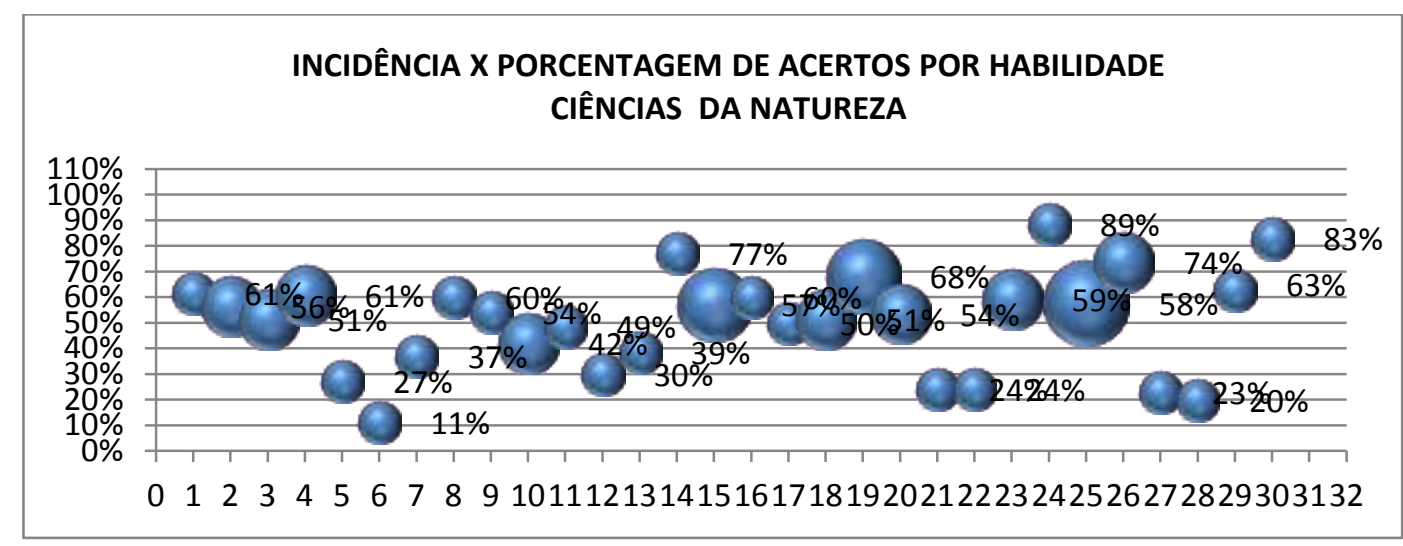

Figura 20 - Ciências da Natureza - Incidência X Porcentagem de acertos por habilidade

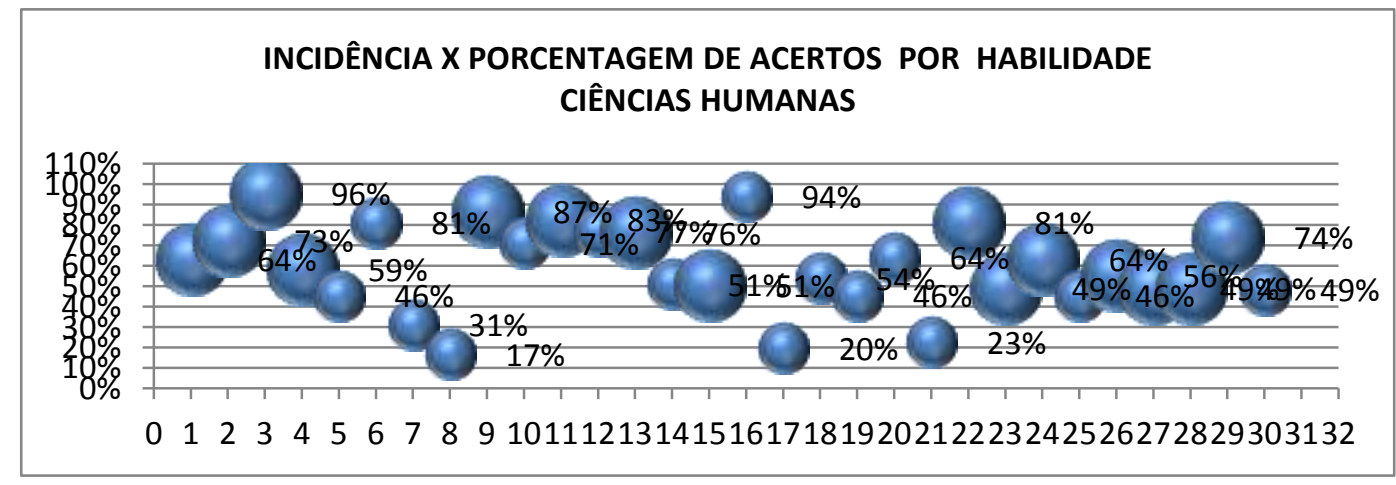

Figura 21 - Ciências Humanas - Importância X Proficiência 


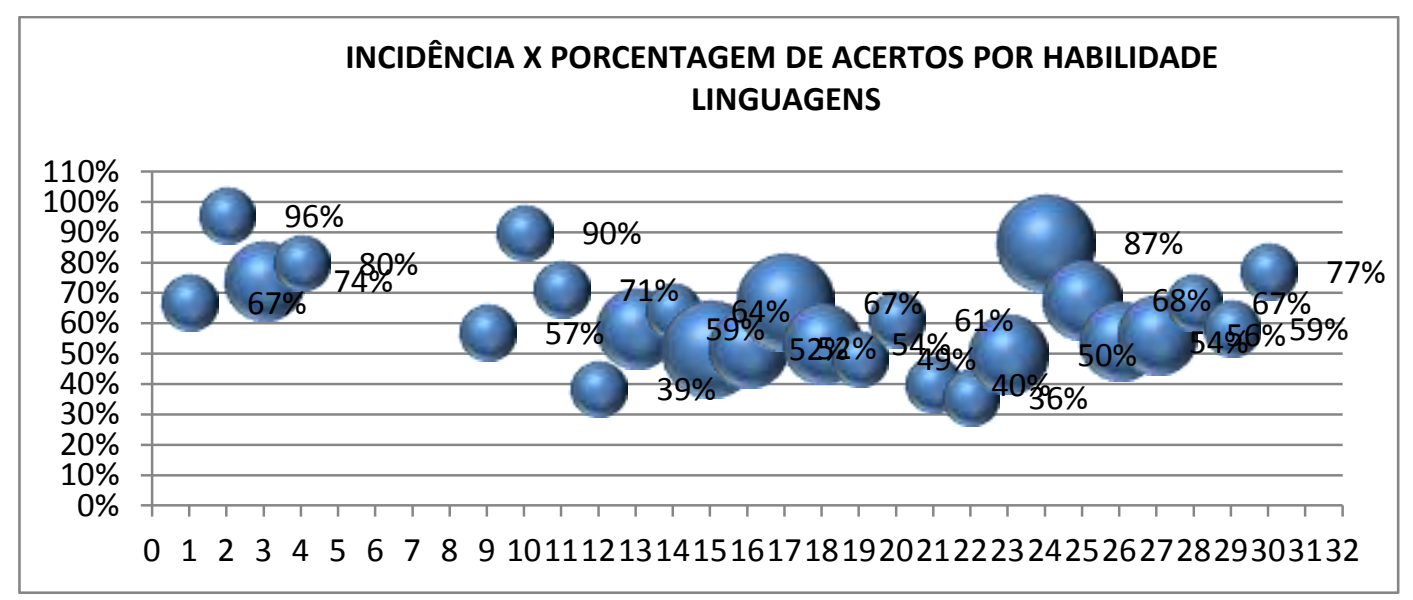

Figura 22 - Linguagens e Códigos - Incidência X Porcentagem de acertos por habilidade

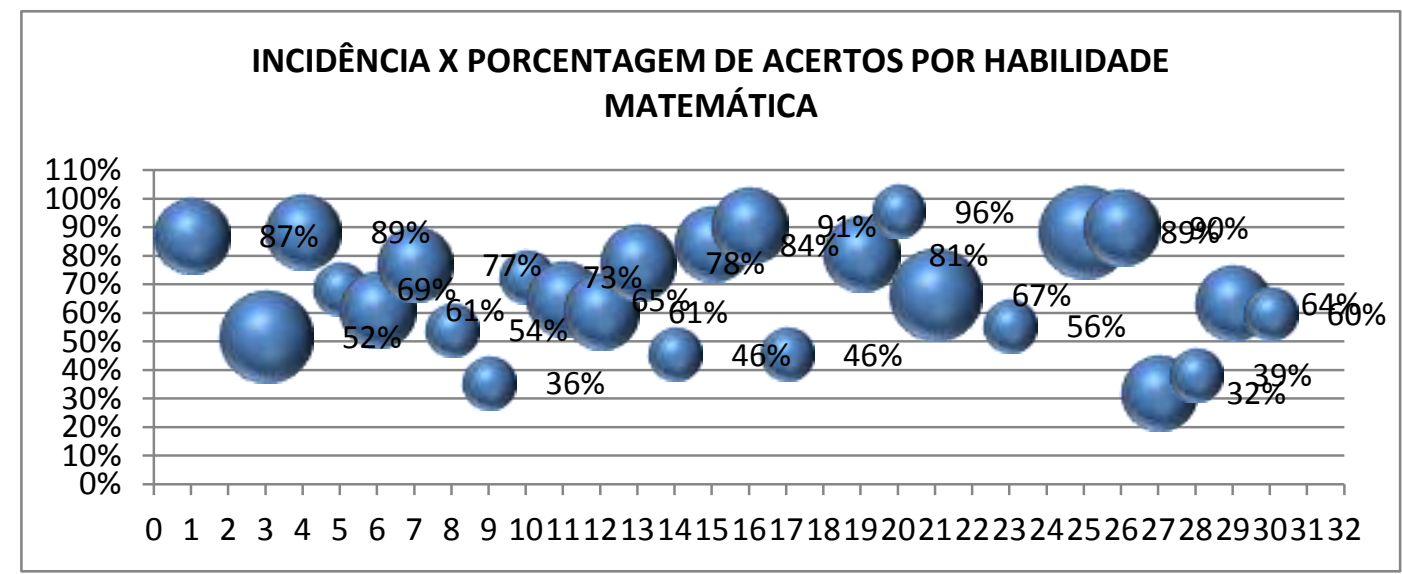

Figura 23 - Matemática - Incidência X Porcentagem de acertos por habilidade

Estes gráficos combinados com os gráficos de porcentagem de acertos por questão dá uma noção bem próxima dos pontos fortes e fracos dos alunos, da mesma forma podemos analisar em que pontos o trabalho desenvolvido no colégio apresenta falhas ou não.

A partir destes resultados, apresentado pelo INEP no final do ano seguinte, cada colégio que tiver acesso a esses dados terá a possibilidade de ratificar ou reconduzir o seu processo pedagógico. 


\subsubsection{Gráfico de distribuição dos alunos do Rio de Janeiro por acertos}

Nestes gráficos estão distribuídos os alunos do Rio de janeiro de acordo com os acertos que apresentaram no exame do ENEM de 2012.

O gráfico da distribuição dos alunos por acerto é interessante, pois abre uma discussão relevante em relação ao modelo da prova. Muitos alunos consideram a prova do ENEM fácil, no entanto, percebe-se claramente que em 45 questões o número de acertos de grande parte dos alunos está entre 20 e $40 \%$ dependendo da área a ser estudada. Observe também que poucos apresentam um número elevado de acertos.

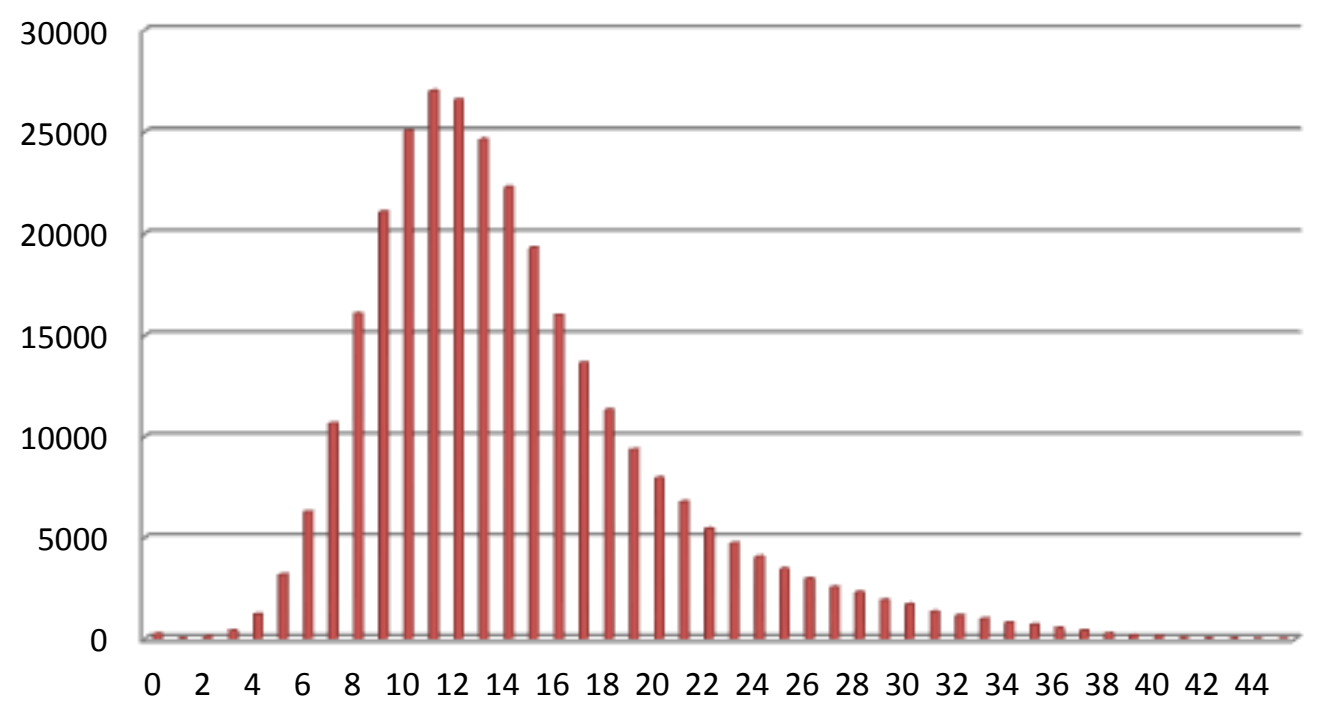

Figura 24 - Ciências da Natureza - Distribuição dos alunos do Rio de Janeiro em relação ao número de acertos 


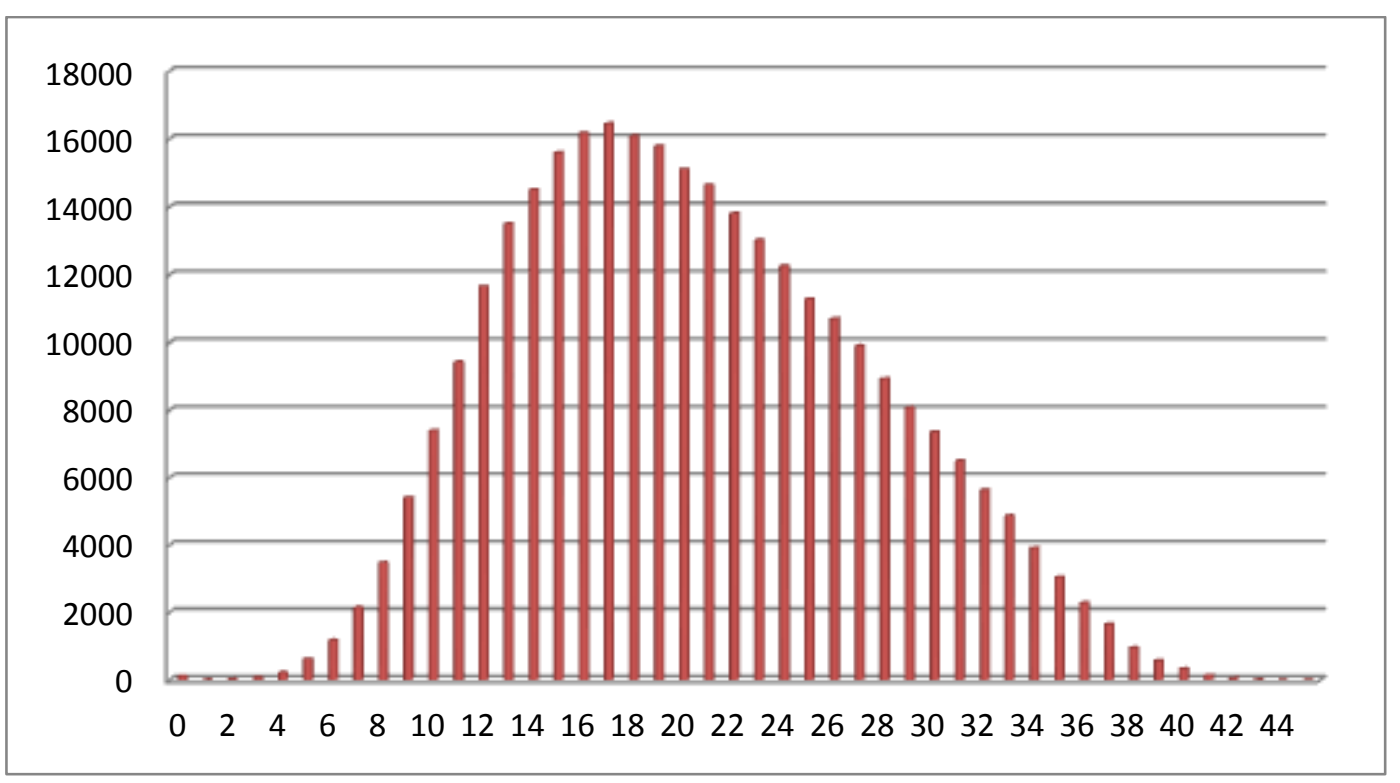

Figura 25 - Ciências Humanas - Distribuição dos alunos do Rio de Janeiro em relação ao número de acertos

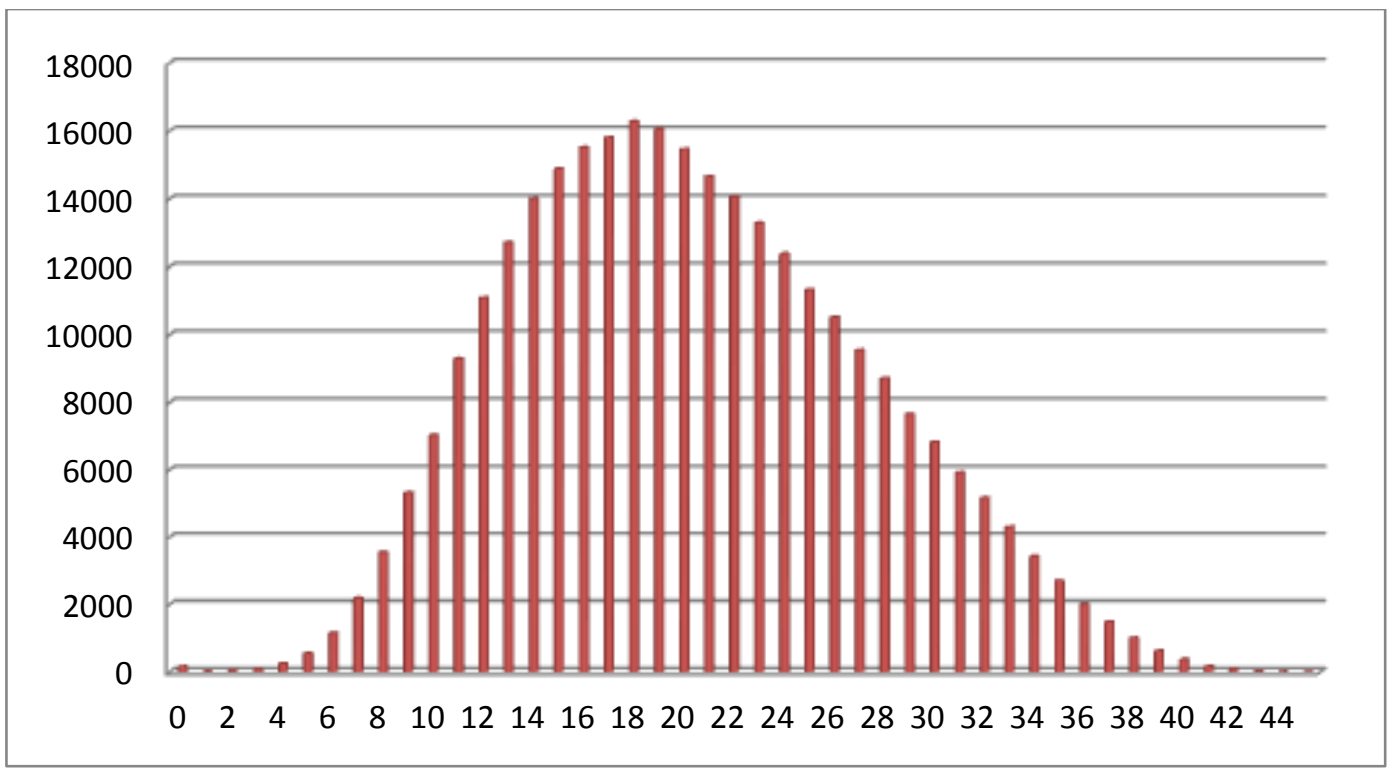

Figura 26 - Códigos e Linguagens - Distribuição dos alunos do Rio de Janeiro em relação ao número de acertos 


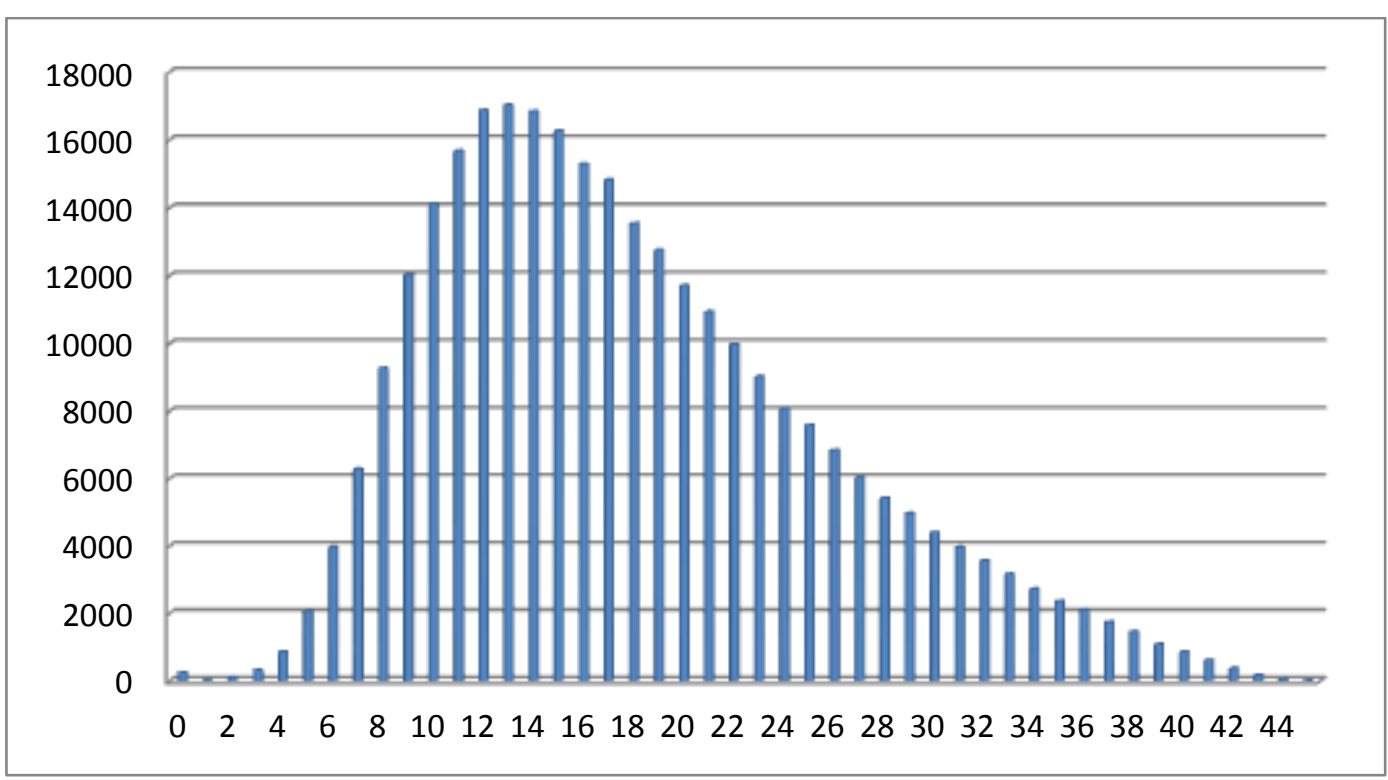

Figura 27 - Matemática - Distribuição dos alunos do Rio de Janeiro em relação ao número de acertos

Nos quatro gráficos a distribuição obedece ao formato de uma curva normal com ligeira tendência à esquerda, no entanto, é nítido que no primeiro dia de exame a média de acertos em Ciências da Natureza foi menor que em Ciências Humanas, e que no segundo dia, a média de acertos em Linguagens foi maior que em Matemática, e talvez um dos motivos seja o de que os alunos dominam a área de linguagens de uma forma mais homogênea, e que em matemática existe um grande grupo que domina muito pouco e um grupo bastante diluído na parte superior dos acertos.

\subsubsection{Gráfico de nota máxima e mínimo em relação ao número de acertos}

Nos gráficos a seguir estão as informações em cada área do conhecimento relacionando as notas obtidas pelos alunos do Rio de Janeiro e o número de acertos. Sabe-se que a nota não é dada em função do número de acertos e em cada gráfico é possível observar de modo claro que se dois alunos tem uma baixa ou uma alta quantidade de acertos as notas diferenciam pouco, no entanto, é possível perceber uma diferença muito alta onde há uma alta concentração de indivíduos, pois há uma variabilidade de resposta expressiva. Cada um dos gráficos adiante pode ser comparado com a distribuição de alunos na mesma área. Em cada um dos gráficos percebe-se visualmente esta diferença, foram assinalados alguns 
resultados que chamam a atenção. Esta talvez seja o maior foco de estranheza dos alunos ao receberem as suas notas. Afinal, esta discrepância entre as notas pode ser fundamental para um aluno entrar ou não na universidade.

Por exemplo, um aluno com 13 acertos tirou 337,6 e outro com a mesma quantidade de acertos tirou 548,9 em Ciências da Natureza. Este mesmo fato ocorre também nas outras áreas de conhecimento.

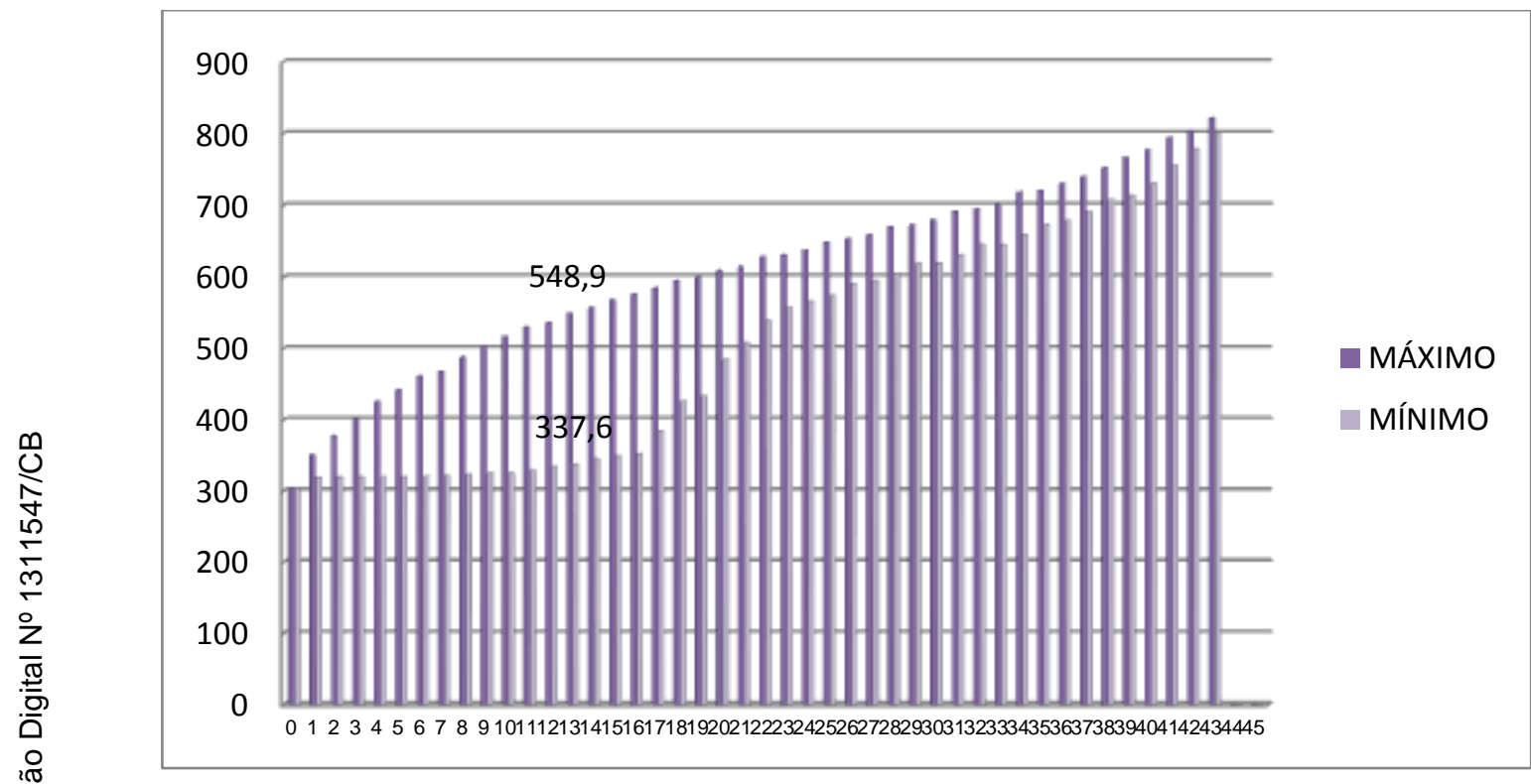

Figura 28 - Ciências da Natureza - Máximo e mínimo por número de acertos 


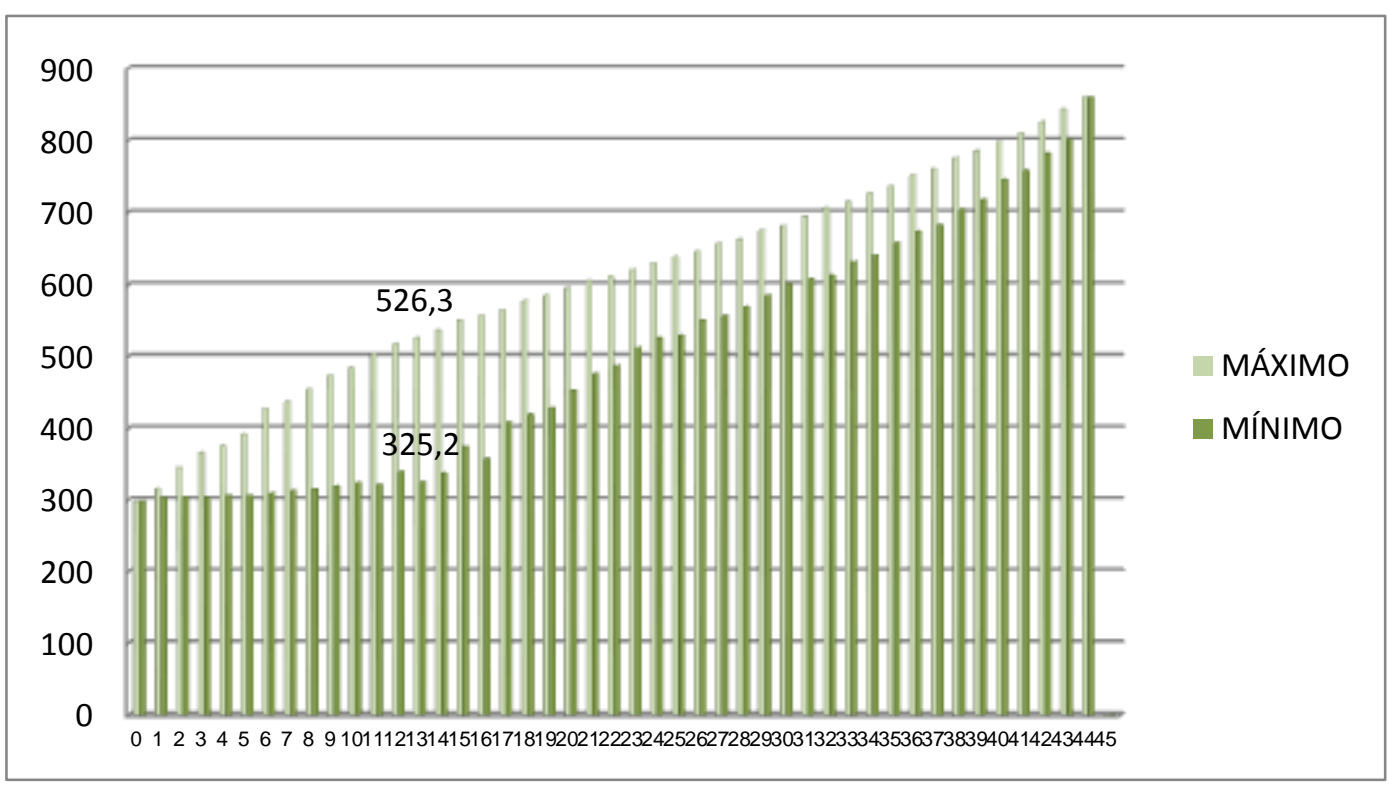

Figura 29 - Ciências Humanas - Máximo e mínimo por número de

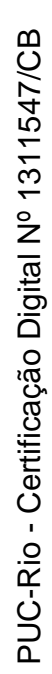
acertos

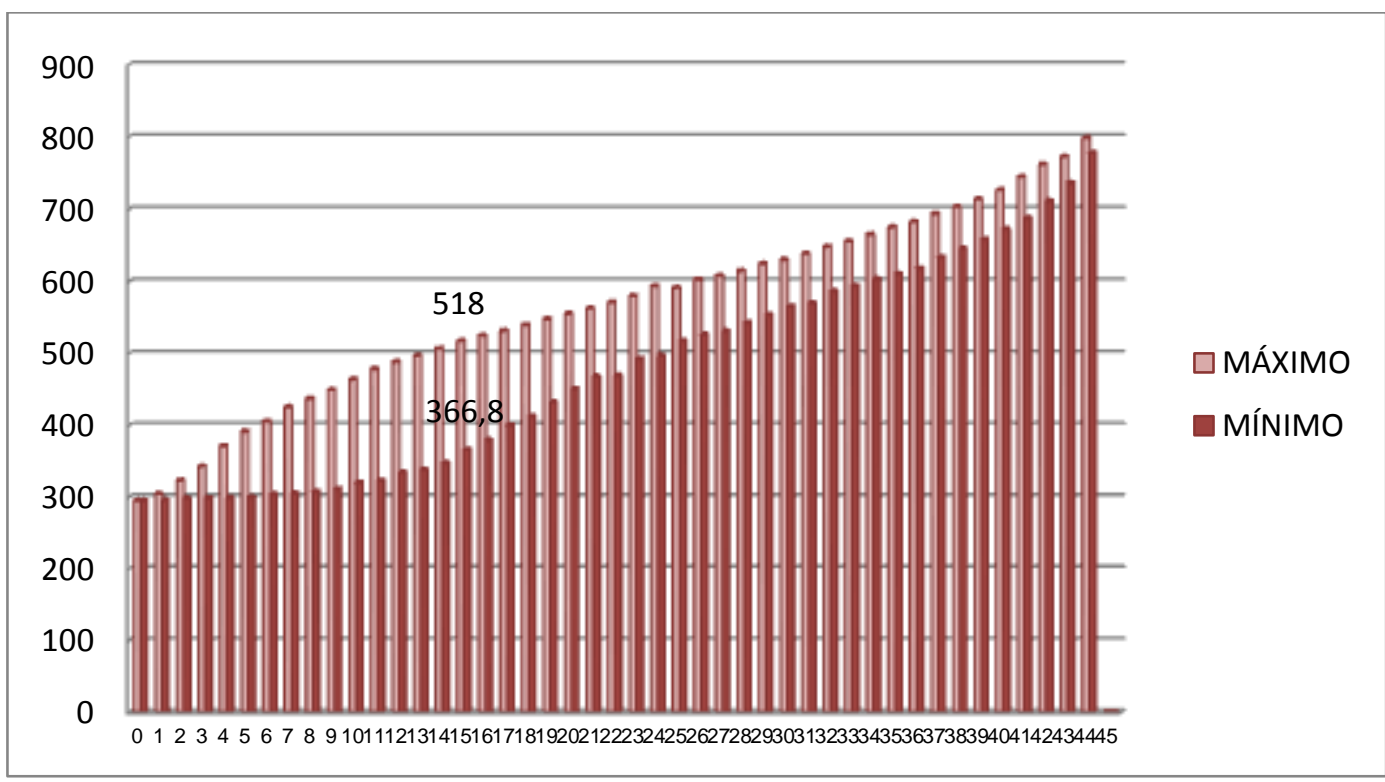

Figura 30 - Códigos e Linguagens - Máximo e mínimo por número de acertos 


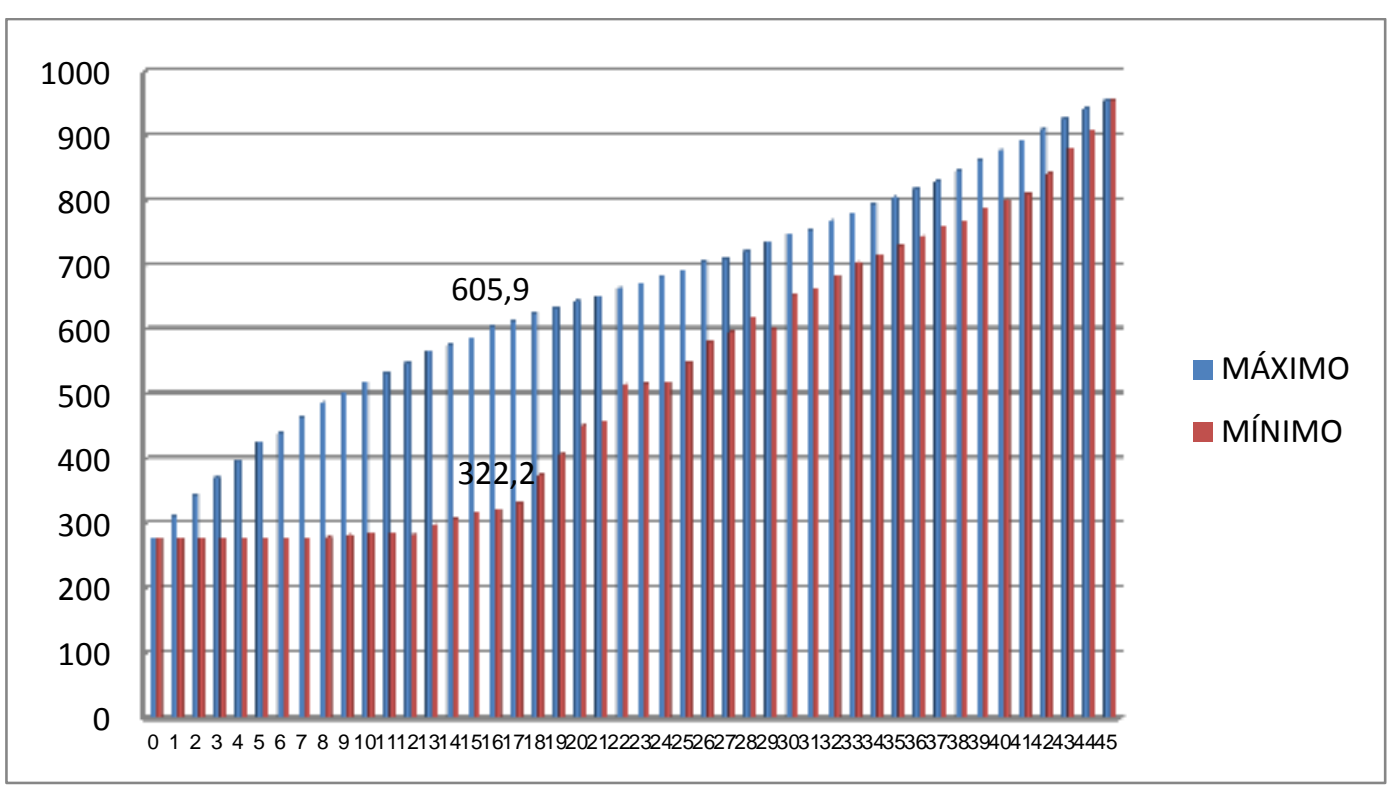

Figura 31 - Matemática - Máximo e mínimo por número de acertos

Os gráficos falam por si, e devem ser divulgados pelas escolas tanto para seus alunos quanto para os responsáveis. Quando se conhece as regras do exame, entende-se também que ser coerente nesta prova é fundamental, que acertar as questões fáceis e médias é mais interessante que acertar as mais difíceis, que para concluir a prova a tempo é fundamental não se prender às questões que considera difícil ou que vai perder muito tempo, deve-se criar uma estratégia para chegar ao final da prova e em seguida retomar os itens que não foram executados. Espera-se de grande parte dos examinandos que itens sejam "chutados", por falta de tempo ou por falta de conhecimento, no entanto, o participante que em todas as áreas, faz a prova com embasamento; que se preparou fisicamente e emocionalmente; que utilizou as provas anteriores para realizar um treinamento e criou para si uma estratégia tem alta probabilidade de ter um bom rendimento. 


\section{4 \\ Ferramentas para extrair dos dados fornecidos pelo INEP os dados de uma determinada escola}

O INEP fornece os dados dos alunos que fizeram a prova do ENEM em sua página. Estes dados são muito grandes e por isso poucas pessoas conseguem filtrar as informações que interessam.

Todos os anos o INEP divulga as notas por escola em cada uma das áreas, no entanto, estas notas correspondem à média dos alunos. As escolas gostariam muito de ter os dados individuais dos seus alunos para que pudessem avaliar o comportamento de cada um deles nas provas, os seus acertos, suas notas e, a partir destas informações corrigirem rumos, definir estratégias, criar projetos pedagógicos e finalmente uma linha de trabalho que culminasse no terceiro ano com uma preparação que permitisse aos seus alunos um rendimento máximo dentro das suas possibilidades.

Ao iniciar este trabalho deparei com dois questionamentos:

1 - como conseguir os dados dos alunos do Colégio onde sou coordenador da terceira série?

2 - após obter este resultado o que seria importante para o diretor de um colégio, ou para sua equipe técnica ou para a sua equipe docente?

A partir das respostas destas duas perguntas dei início ao meu trabalho. Busquei as informações do Colégio onde sou o coordenador, e percebi que poderia estender este conhecimento a outras escolas e dividir com outros coordenadores estes dados.

Pensei em criar um aplicativo onde qualquer pessoa pudesse ter informações a respeito do seu colégio, mas se fizesse isso todos os anos teria que repetir o processo e as pessoas continuariam com dificuldades para obter os seus dados.

Escrever como era o processo para a obtenção dos dados estimulariam outros profissionais a buscarem os seus resultados que teriam como aprimorar a linha de ação de suas escolas. 
O maior ganho que tive com este trabalho foi a busca pelo conhecimento do programa Excel. A cada momento em que eu decidia o que queria buscar em seguida vinha a angustia, do como fazer, que ferramentas teriam que ser usadas e qual o melhor caminho a seguir. Esse modo de agir me deu muito estímulo para buscar mais conhecimentos. Espero que com estas informações consiga também ajudar a outras pessoas, por isso procurei colocar quase um passo a passo do processo que usei. Sempre que necessário indicarei que ferramentas devem ser dominadas. Nas próximas seções vamos descrever os comandos do EXCEL.

\subsection{0 passo a passo}

\subsubsection{Onde encontrar os dados disponíveis}

Entrar no portal INEP, no endereço http://portal.inep.gov.br/.

Clique em Portal do INEP > INFORMAÇÕES ESTATÍSTICAS > MICRODADOS $>$ MICRODADOS PARA DOWNLOAD > MICRODADOS ENEM (ANO QUE DESEJA A INFORMAÇÃO) > SALVAR .

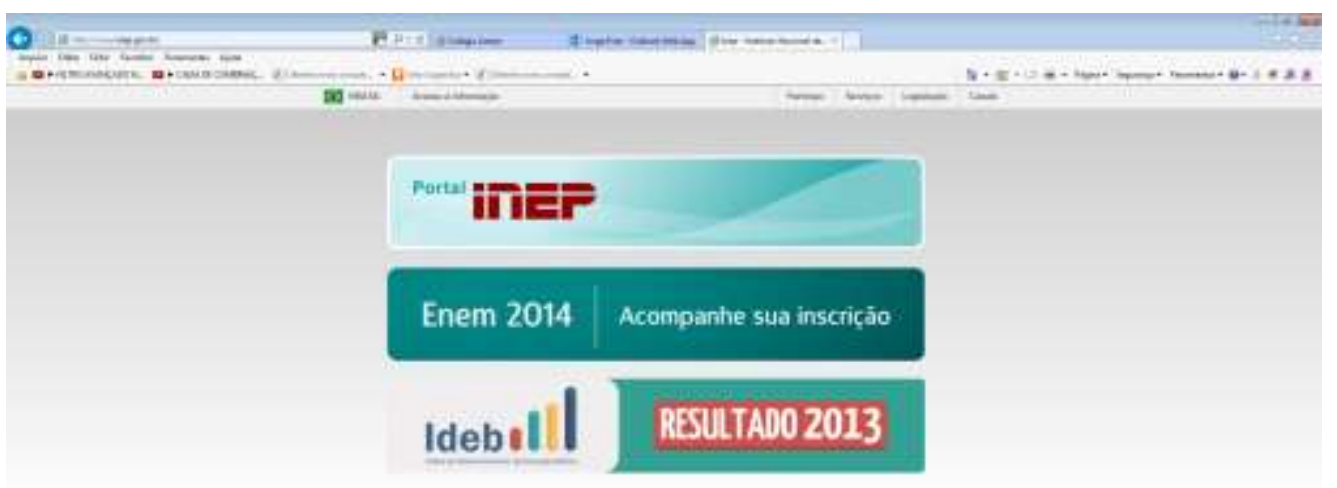

Figura 32 - Portal do INEP. 


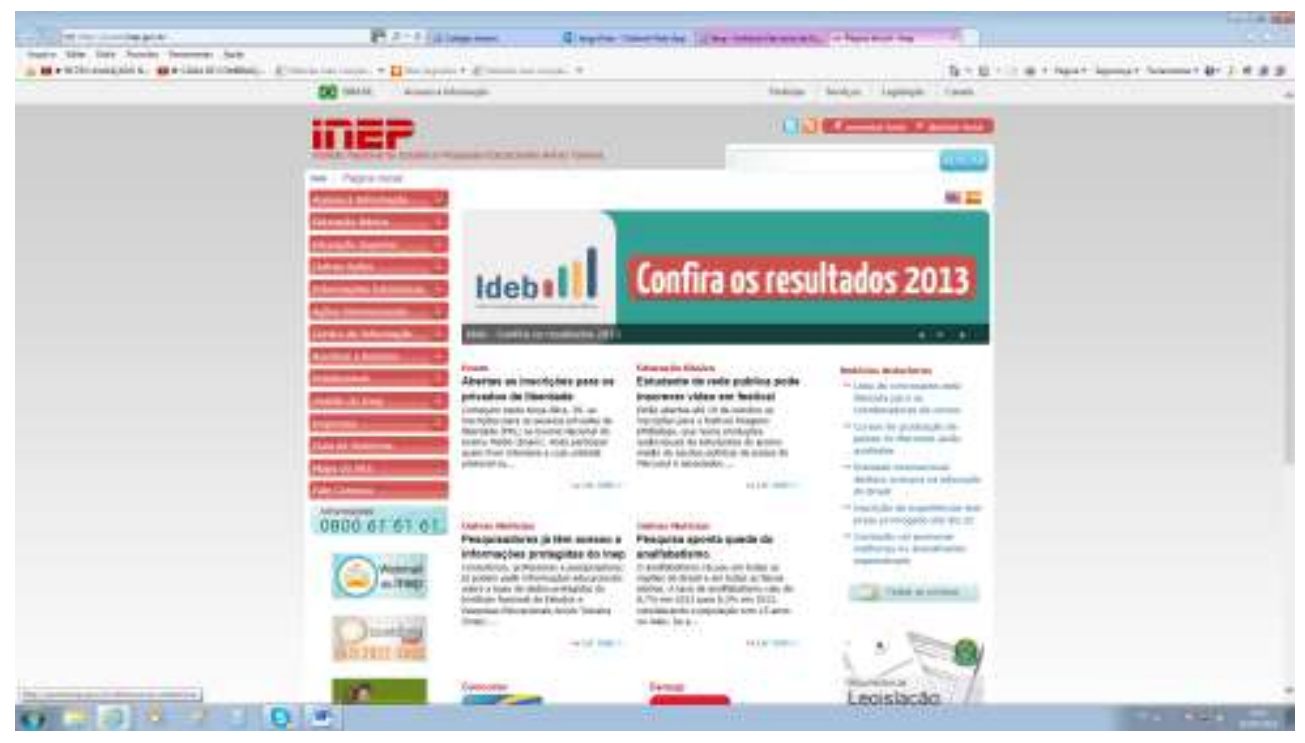

Figura 33 - Informações estatísticas.

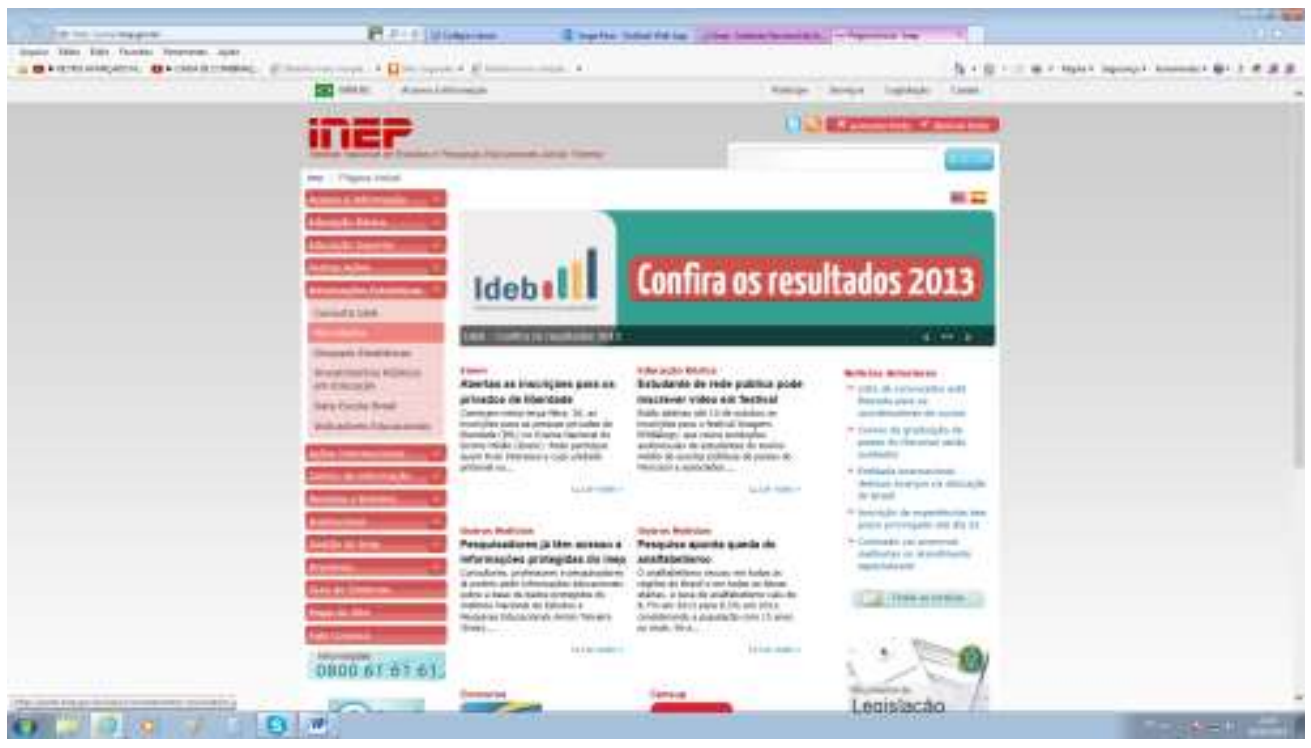

Figura 34 - Microdados. 


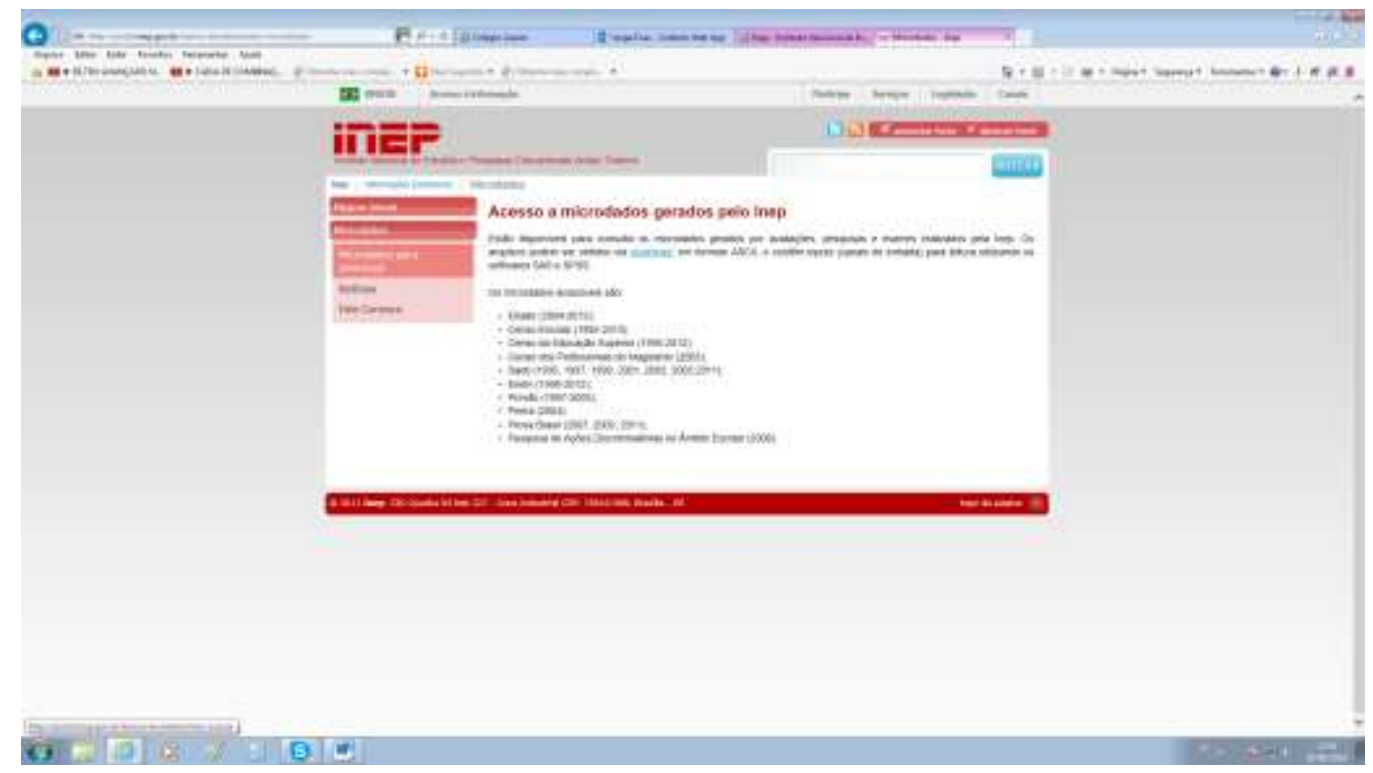

Figura 35 - Microdados para download.

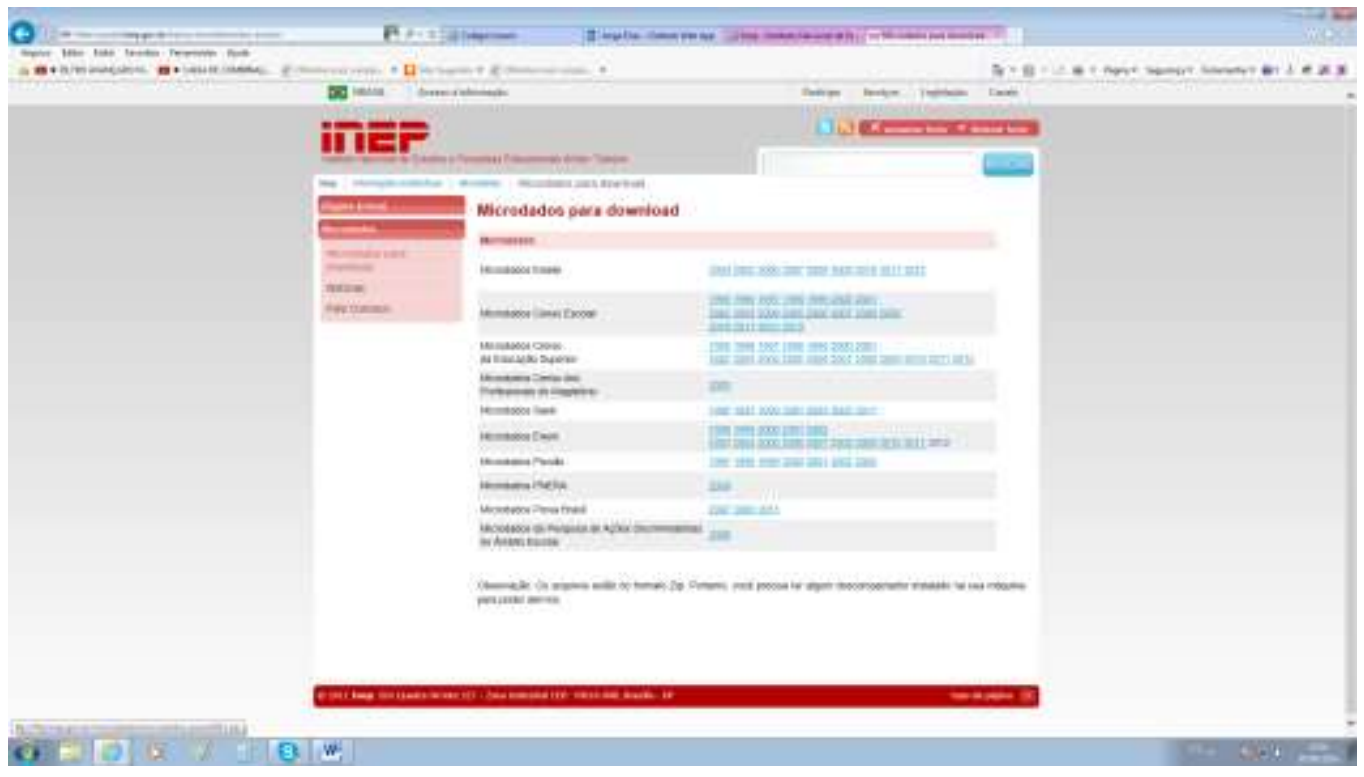

Figura 36 - Microdados ENEM (ano que deseja a informação).

$\mathrm{O}$ arquivo com os dados vem no formato .zip.

Ao baixar o arquivo percebe-se que mesmo compactado apresenta aproximadamente $3 \mathrm{~Gb}$ de tamanho. Este é o primeiro problema a enfrentar, pois apenas computadores com maior velocidade devem baixar os dados. Neste trabalho utilizamos um Sony Vayo, I5, com memória de $6 \mathrm{~Gb}$. .

Resolvi que estudaria o grupo de alunos do Rio de Janeiro, isto já diminuiria o tamanho do arquivo. Ainda assim, teria que baixar tudo e filtrar os alunos do estado em questão. 
Para conseguir baixar o arquivo tivemos que dividi-lo em 20 partes, filtrei cada um deles de modo a copiar todos os alunos do Rio de Janeiro, e colei cada arquivo em um novo arquivo Excel apenas com alunos do grupo de interesse.

Em Linux, alguns comandos podem facilitar esta tarefa da subdivisão. Consulte na internet o comando split.

\subsubsection{A Pesquisa e as Ferramentas}

A partir deste momento começa o meu trabalho de fato.

A pesquisa tem dois movimentos:

1 - Organizar o que um coordenador gostaria de obter destes dados.

2 - Identificar que ferramentas do Excel eu teria que dominar para alcançar o meu objetivo.

Portanto, o trabalho terá este encaminhamento, a definição do objetivo a alcançar e o conhecimento necessário para atingir este objetivo.

\subsubsection{Filtrar os dados dos alunos do Colégio}

OBJETIVO 1 - Filtrar os dados dos alunos que estudaram no Colégio em que sou coordenador, ou dos alunos de outro Colégio que interesse.

Ferramenta necessária do EXCEL: Filtro

Disponibilizei nos links abaixo os dados do ENEM 2012 em Excel:

Se o leitor é do Rio de Janeiro acesse o link abaixo:

https://drive.google.com/file/d/OByhpXU8vBCVTY19jSkJyZOhpVVE/view?us $\mathrm{p}=$ sharing

É um arquivo grande e pode demorar a ser aberto.

É importante conhecer os cabeçalhos que aparecem na primeira linha do Excel. Indiquei desta forma para facilitar a consulta, a saber:

CIDADE - Cidade onde se encontra o Colégio

UF - Unidade Federativa

CÓDIGO_DO_COLÉGIO - Código do Colégio no Educacenso

NCN - Nota de Ciências da Natureza

$\mathrm{NCH}$ - Nota de Ciências Humanas 
NLC - Nota de Linguagens e Códigos

NMT - Nota de Matemática

NR - Nota de Redação

RCN - Respostas de Ciências da Natureza

RCH - Respostas de Ciências Humanas

RLC - Respostas de Linguagens e Códigos

RMT - Respostas de Matemática

CN - Número da prova de Ciências da Natureza

$\mathrm{CH}$ - Número da prova de Ciências Humanas

LC - Número da prova de Linguagens e Códigos

MT - Número da prova de Matemática

L - Língua Estrangeira - Inglês ou Espanhol

GCN - Gabarito de Ciências da Natureza

GCH - Gabarito de Ciências Humanas

GLC - Gabarito de Linguagens e Códigos

GMT - Gabarito de Matemática

C1 - Nota na Competência 1 de Redação

C2 - Nota na Competência 2 de Redação

C3 - Nota na Competência 3 de Redação

C4 - Nota na Competência 4 de Redação

C5 - Nota na Competência 5 de Redação

TO - Nota de Redação

Ao abrir o arquivo:

a) Marque a primeira linha e na aba Dados clique em filtro (Figura 37).

b) Na coluna CÓDIGO_DO_COLÉGIO clique na seta e ao abrir a caixa de busca escreva o Código do Colégio no Educacenso (Figura 38).

c) Copie a planilha relativa ao colégio e cole numa nova planilha.

d) Dê um nome a sua planilha, por exemplo, COLEGIO_XX , e salve-a.

e) Exclua as colunas com os dados que não lhe interessa, assim, o arquivo ficará menor.

f) Mantenha o número do aluno, a nota de cada área, a nota de cada Competência da Redação, as respostas de cada área e o gabarito de cada área, o número referente a cada prova, eles estão relacionados às cores das provas. 
g) "Na coluna nota, selecione todas as células, na aba selecionar e substituir, em localizar coloque “" e, em substituir coloque “," Assim estará garantindo que os dados são números e não texto.

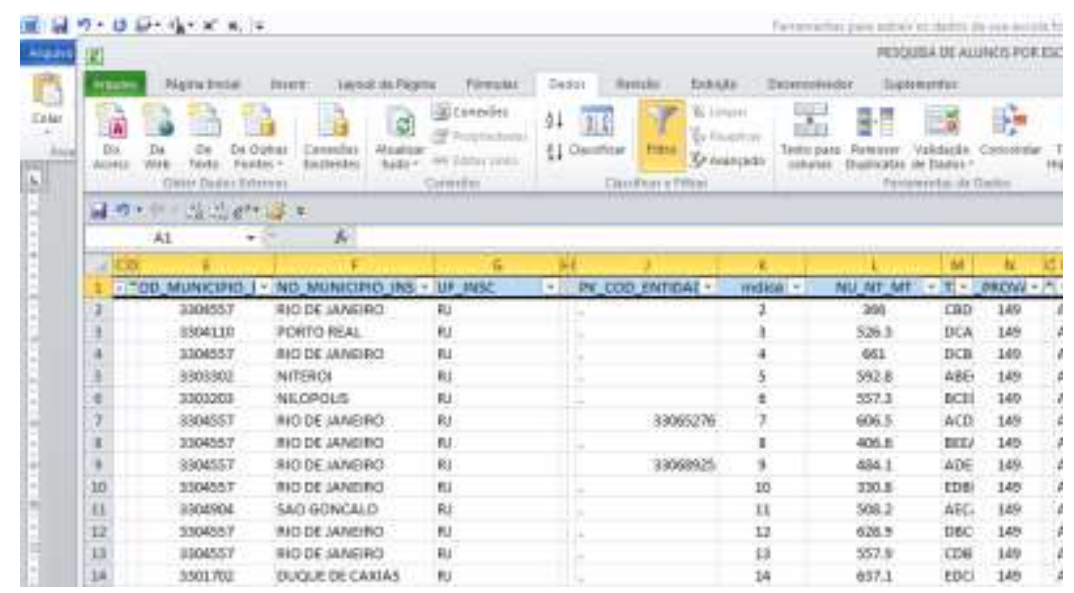

Figura 37 - Pesquisar usando Filtro.

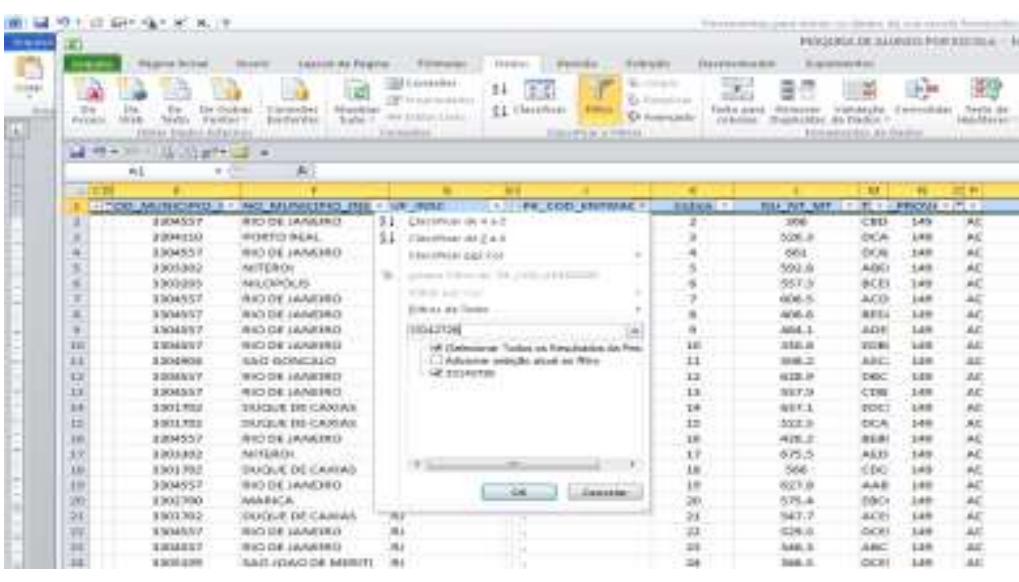

Figura 38 - Selecionar usando o código do Colégio.

Se o leitor é de outro estado qualquer da federação, deverá entrar num outro arquivo contendo os dados de todas as escolas do Brasil.

$\mathrm{O}$ arquivo do INEP foi dividido em 20 arquivos menores, facilitando assim a busca, já que o arquivo inteiro é muito grande.

Ao clicar no link encontrará os arquivos numerados de 1 a 20, abra um arquivo de cada vez, e em cada um dos arquivos faça a busca dos dados que lhe interessa. 
Ao abrir o arquivo perceberá que existem muitos dados que são importantes para a sua pesquisa, por isso é interessante entender do que se trata cada cabeçalho de cada coluna para iniciar a pesquisa.

Se o leitor é não é do Rio de Janeiro no Apêndice II terá as informação para obter os dados de outros estados. acesse o link abaixo:

https://drive.google.com/folderview?id=0ByhpXU8vBCVTVjdwbnJYTGx

\section{$\underline{\text { ZUEE\&usp }=\text { sharing }}$}

\subsubsection{Analise da distribuição dos alunos por nota em cada área}

OBJETIVO 2 - Construir o Gráfico da Distribuição dos alunos em cada área do conhecimento.

Ferramenta do Excel: Função Frequência

O INEP divulga a média de cada Escola, a média dos alunos da escola é um dado relevante, mas saber como os alunos tiraram estas notas com certeza é mais interessante, pois se pode pensar estrategicamente para os grupos posteriores retificando procedimentos, por isso, agrupar os alunos por suas notas dá aos coordenadores e professores uma boa ideia do que aconteceu.

$\mathrm{Na}$ faixa inicial estão os alunos com notas abaixo de 300 e as faixas restantes sofrem um acréscimo 50 pontos (Figura 39).

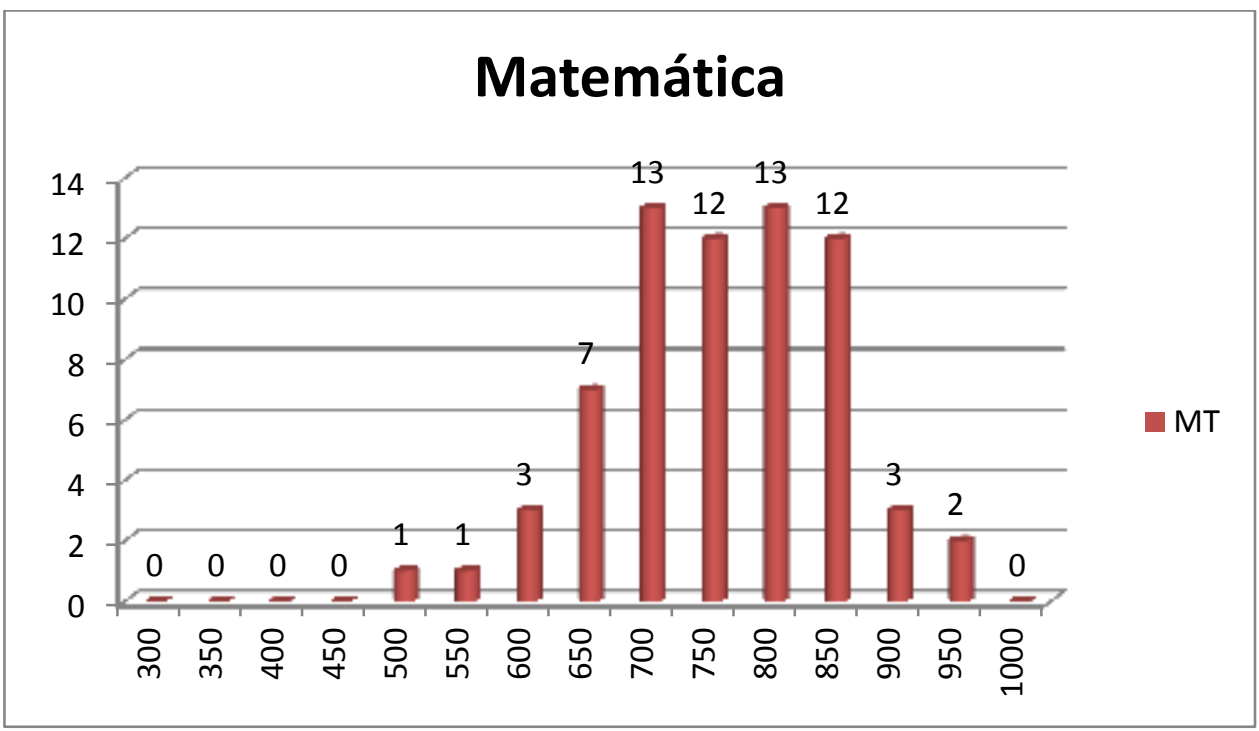

Figura 39 - Matemática - Distribuição de alunos.

Suponha que os dados das notas dos alunos em Matemática estejam na coluna A da planilha COLEGIO_XX, e eu esteja querendo distribuir por faixa de 
notas os seus alunos. Deve-se usar a função frequência na forma matricial que tem o seguinte formato:

$\{=$ FREQUÊNCIA (MATRIZ_DADOS;MATRIZ_BIN) \}

MATRIZ_DADOS é a matriz de onde queremos retirar os dados, neste caso, na planilha COLEGIO_XX, a coluna referente, por exemplo, a área de Matemática.

MATRIZ_BIN é a matriz que indica como se quer distribuir os alunos.

Para se construir a distribuição a função deve ser escrita da seguinte forma:

1 - Selecione a coluna onde se quer distribuir os alunos. Por exemplo, na tabela abaixo, selecione a coluna D3 a D17.

2 - Escreva na caixa de função:

=FREQUÊNCIA (A2:A69;C3:C16)

Clique simultaneamente nas teclas SHIFT, CONTROL E ENTER e a na caixa de função, a função frequência aparecerá entre chaves, pois ela funciona como uma função matricial:

$\{=$ FREQUÊNCIA (A2:A69;C3:C17) $\}$

A coluna contendo os alunos em cada faixa é completada automaticamente (Tabela 11).

Tabela 2 - Matemática - Distribuição dos alunos do A. Liessin por suas notas.

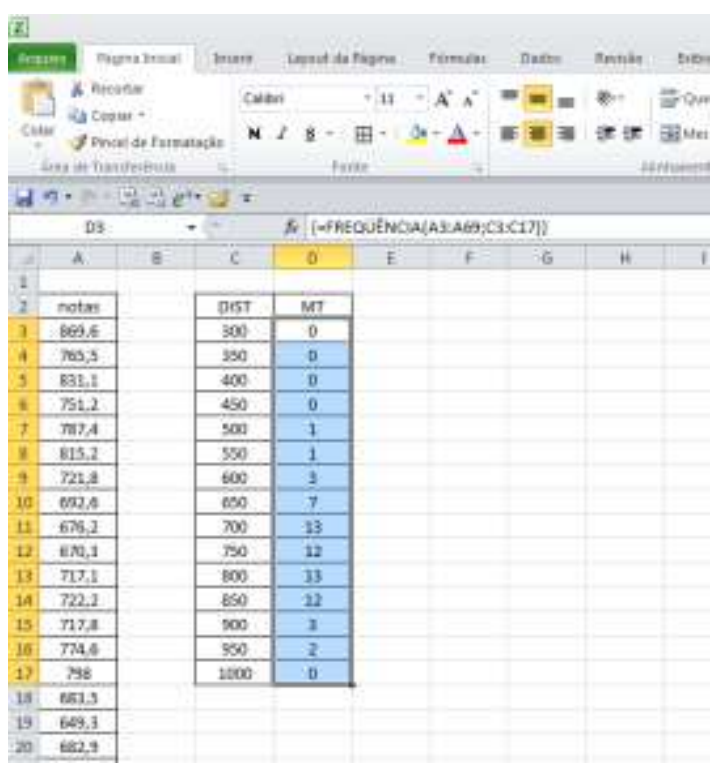

Para construir o gráfico selecione o intervalo C2 a D17, na aba Inserir $>$ gráfico de colunas $>$ escolha o tipo. 


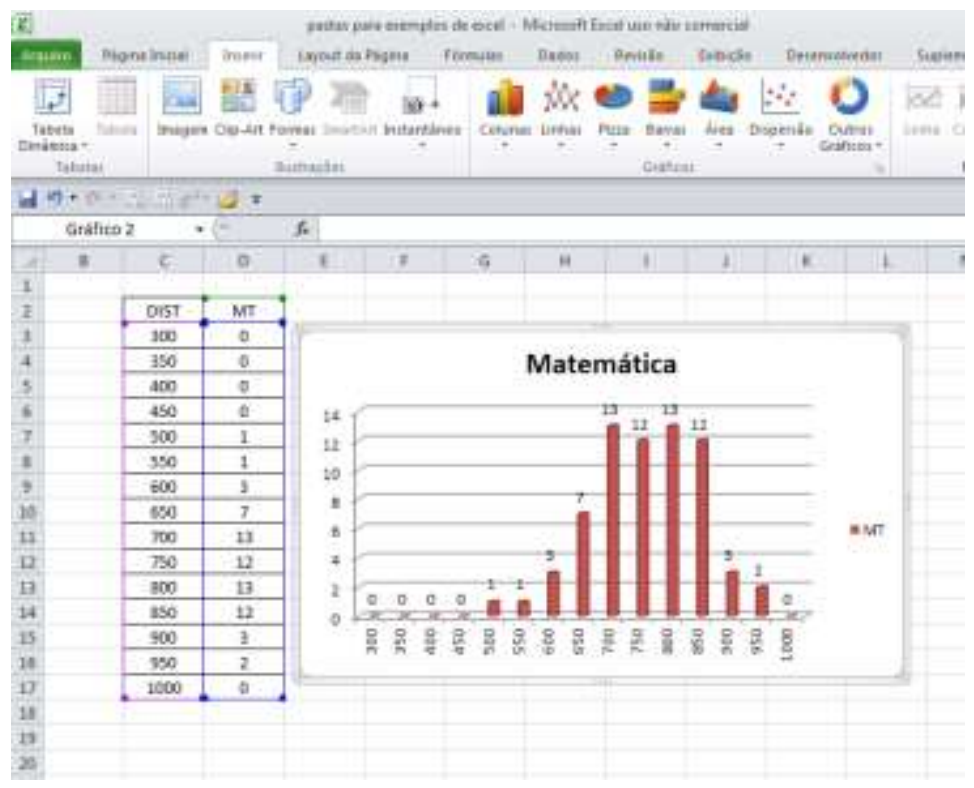

\section{Figura 40 - Construção de gráfico de frequência}

Vão aparecer duas colunas em cada faixa, os valores relativos à faixa de notas e os valores relativos ao número de alunos em Matemática, portanto, clique com o botão esquerdo do mouse e clique em selecionar dados.

No campo Entrada de Legendas, clique em DIST e no botão Remover. No campo Rótulo do Eixo Horizontal, clique em Editar, selecione a coluna de cabeçalho DIST, ou seja, na figura acima, os campos de C3 a C17, imediatamente no eixo das abscissas do gráfico aparecem os valores das faixas e as colunas referentes ao número de alunos, clique em OK.

Clique com o botão esquerdo sobre uma das colunas e em Adicionar Rótulos de Dados (Figura 39).

Agora que distribuímos os alunos em cada faixa de notas em Matemática, basta repetirmos a mesma operação para as outras áreas de conhecimento.

Para poder comparar o resultado da sua escola com uma amostra maior no mesmo link está um arquivo com todos os resultados dos alunos do estado do Rio de Janeiro com o nome "DISTRIBUIÇÃO DAS NOTAS DOS ALUNOS DO ESTADO DO RIO DE JANEIRO”

\subsubsection{Análise das questões acertadas pelos alunos}

OBJETIVO 3: Identificar quais questões os alunos acertaram 


\section{FERRAMENTA DO EXCEL: PROCV, PROC H, EXT.TEXTO e SE.}

Saber a nota do ENEM não significa saber que questões foram acertadas, pois com a correção utilizando o TRI não podemos relacionar o número de acertos com a nota final, conforme já mencionamos no início deste trabalho, portanto, devemos conhecer em cada prova:

a) O código do item (questão).

b) As questões correspondentes em cada cor de prova, isto é, em matemática a questão de código 10547, que está relacionada à habilidade 4 da Competência 1 , é a número 1 da prova amarela, a número 10 na prova cinza, a número 9 da prova azul e a 22 na prova rosa.

c) A habilidade relativa a cada questão.

d) Se o aluno acertou ou não cada um dos 45 itens de cada prova e quantos foram os acertos de cada item.

Para isso é necessário conhecer novas ferramentas que permitam mais esta parte da pesquisa.

\section{Função PROCV}

A função PROCV tem o objetivo de conhecido um elemento da primeira coluna de uma planilha encontrar o correspondente a ele em uma determinada coluna. O formato da função PROCV é: começar sempre com o sinal de " = " PROCV(valor_procurado;matriz_tabela;núm_índice_coluna;[procurar_intervalo])

Tem quatro elementos, a saber:

a) valor_procurado: é o elemento que conhecemos

b) matriz_tabela: é a matriz onde estão os dados

c) núm_índice_coluna: é o número da coluna onde está o correspondente ao elemento que conhecemos.

d) [procurar_intervalo]: se desejar o elemento exato escreva 0 ou falso, se desejar uma valor aproximado, escreva 1 ou verdadeiro.

Por exemplo:

$\mathrm{Na}$ célula I3, no quadro abaixo, quando escrevo a seguinte função: $=\mathrm{PROCV}(\mathrm{H} 3 ; \mathrm{B} 2: \mathrm{F} 8 ; 5 ; 0)$. Estou procurando a nota do PEDRO $(\mathrm{H} 3)$, na Matriz dada (B2:F8), em MATEMÁTICA que está na $5^{\mathrm{a}}$ coluna. 


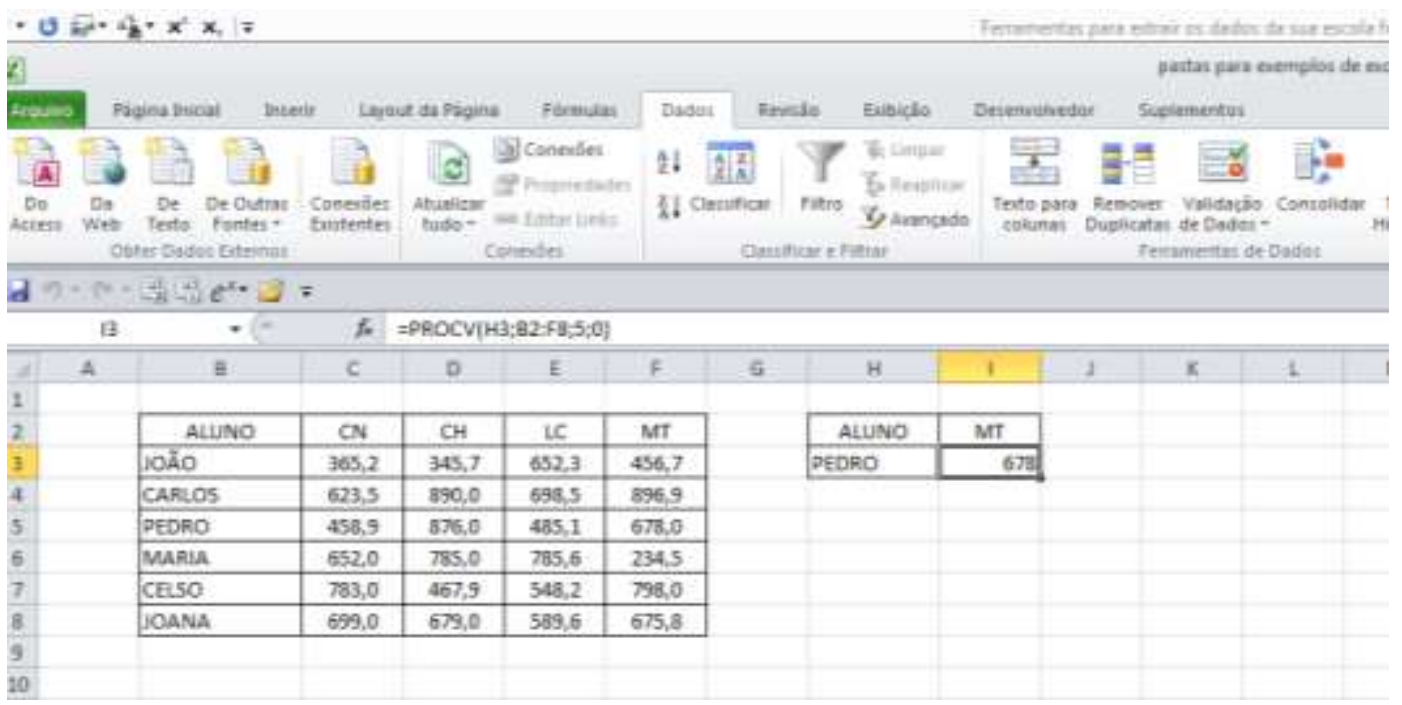

\section{Figura 41 - função PROCV}

Devemos nos preocupar com duas coisas, a primeira é que o valor procurado deve estar na coluna à esquerda do elemento procurado e a segunda, se tiver dois elementos na mesma coluna a função apresenta o correspondente ao primeiro valor encontrado. Por isso o nome PROCV, ele procura na vertical o elemento conhecido e em seguida busca na horizontal o elemento desejado.

\section{Função PROCH}

Possui o mesmo formato da anterior com a característica de procurar na horizontal e em seguida na vertical.

Por exemplo, se estamos procurando a nota de PEDRO (I3) em MATEMÁTICA ( $5^{\mathrm{a}}$ linha), temos que escrever na célula $\mathrm{J} 3$ a fórmula: = PROCH(I3;A2:G6;5;0).

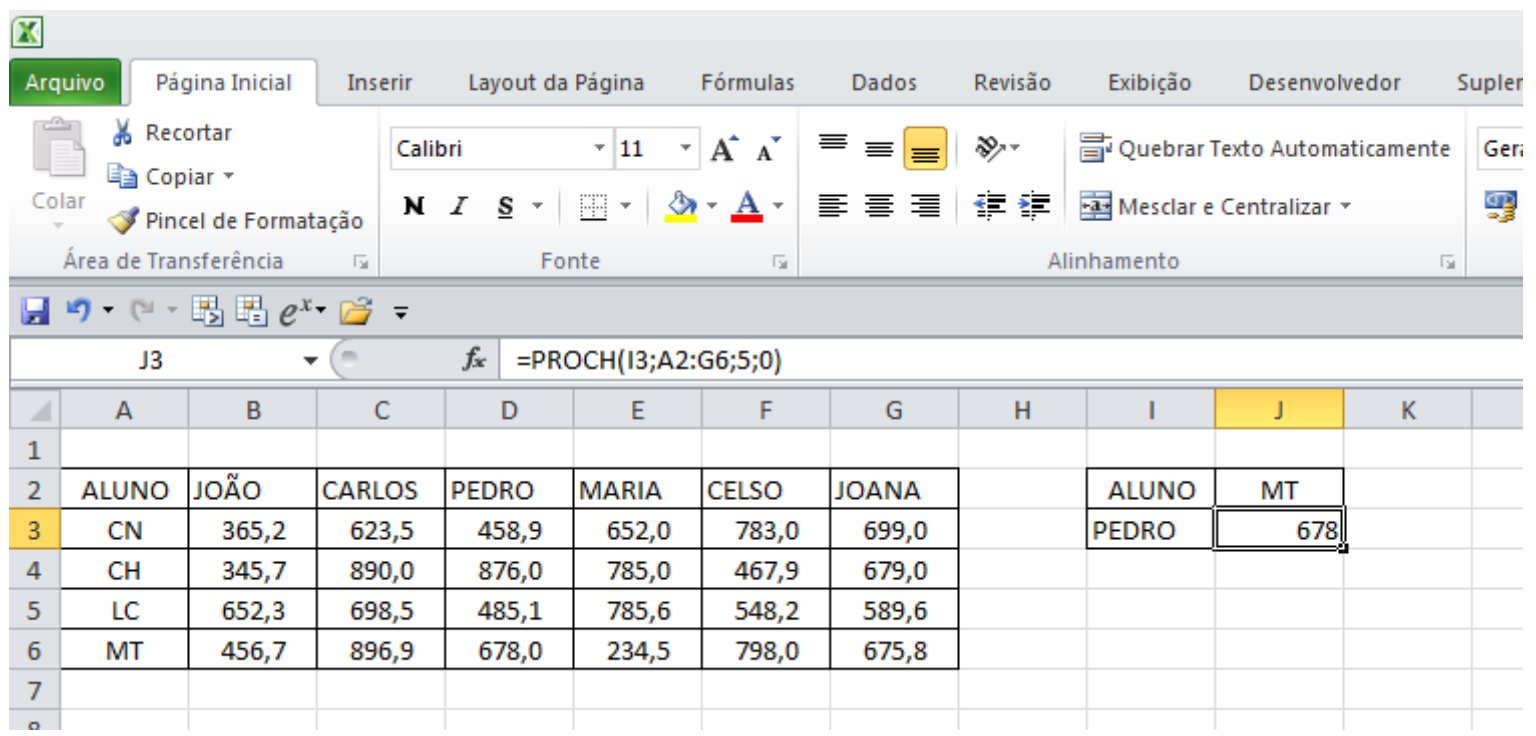




\section{Função EXT.TEXTO}

A função EXT.TEXTO serve para se extrair de um texto, frase ou nome um fragmento, tem a seguinte configuração:

$=$ EXT.TEXTO(TEXTO;NÚM_INICIAL;NÚM_CARACT).

a) Em TEXTO escreva a célula em que se encontra o texto.

b) Em NÚM_INICIAL a posição a partir da qual deseja retirar o fragmento do texto.

c) Em NÚM_CARACT quantos caracteres deseja ter no fragmento.

Na figura 42 estão na célula B2 as respostas de um determinado aluno na forma de um vetor, isto é, as 45 respostas da prova de matemática estão colocadas uma ao lado da outra em uma sequência, ao lado está o ID da prova, isto é cada número representa uma cor de prova, em seguida outro vetor com o gabarito da prova, desta forma, para cada aluno informa-se as suas respostas e o gabarito para cada questão.

Se quiser reconhecer que letra o aluno atribuiu como resposta a cada questão, basta usar a função extrair texto da seguinte forma: $O$ texto será a célula onde estão as respostas do aluno; o número inicial, será o número da questão e; o número de caracteres, colocaremos o número 1 , pois só queremos o resultado de uma questão por vez.

Perceba que na célula E2 escrevi: =EXT.TEXTO $(\$ B 2 ; E \$ 1 ; 1)$, o sinal $\$$ quando inserido serve para manter a leitura em linha ou coluna, isto é, em \$B2, significa que vou ler apenas na coluna $B$, mesmo que copie e cole no sentido horizontal estará sempre referindo-se aos dados da coluna B. Em contrapartida, no formato E\$1, independente do deslocamento para copiar e colar será lido apenas os dados da linha 1 , que refere-se ao número da questão. 


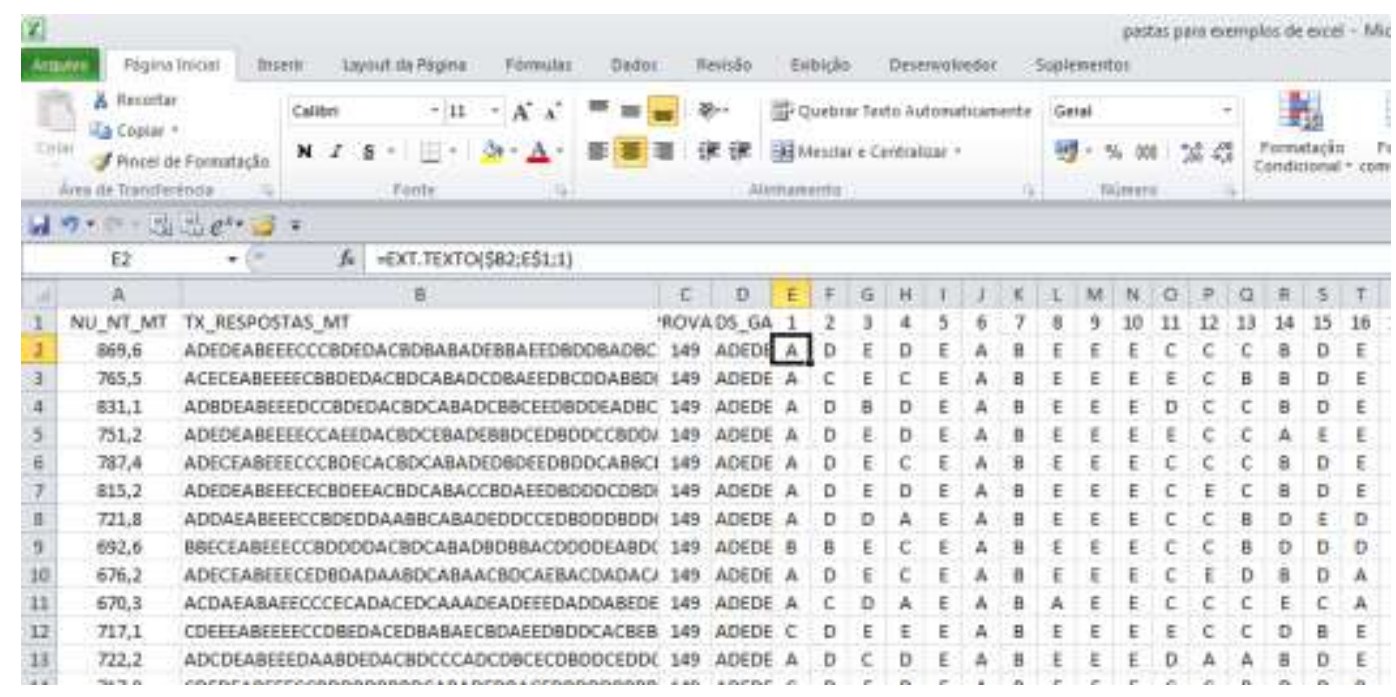

Figura 42 - Resposta por questão

\section{Função SE}

A função SE serve para tomada de decisão. Sua sintaxe leva em conta três aspectos, um questionamento, uma resposta se o resultado for verdadeiro e outra resposta se o resultado for falso. O seu formato é:

\section{SE (TESTE LÓGICO;[VALOR_SE_VERDADEIRO];[VALOR_SE_FALSO])}

$\mathrm{Na}$ figura 43 temos a nota, o quadro de respostas, a cor da prova e o gabarito da prova de Matemática de um determinado colégio. É possível conhecer os acertos e os erros de cada aluno usando a função SE combinada com a função EXT.TEXTO. Na célula E2 inseri a função SE com o seguinte teste lógico: a letra dada como resposta à questão é igual a letra do gabarito da questão 1 ? Se for igual, o aluno acertou e recebe o valor 1 e se for diferente, recebe o valor 0 . 


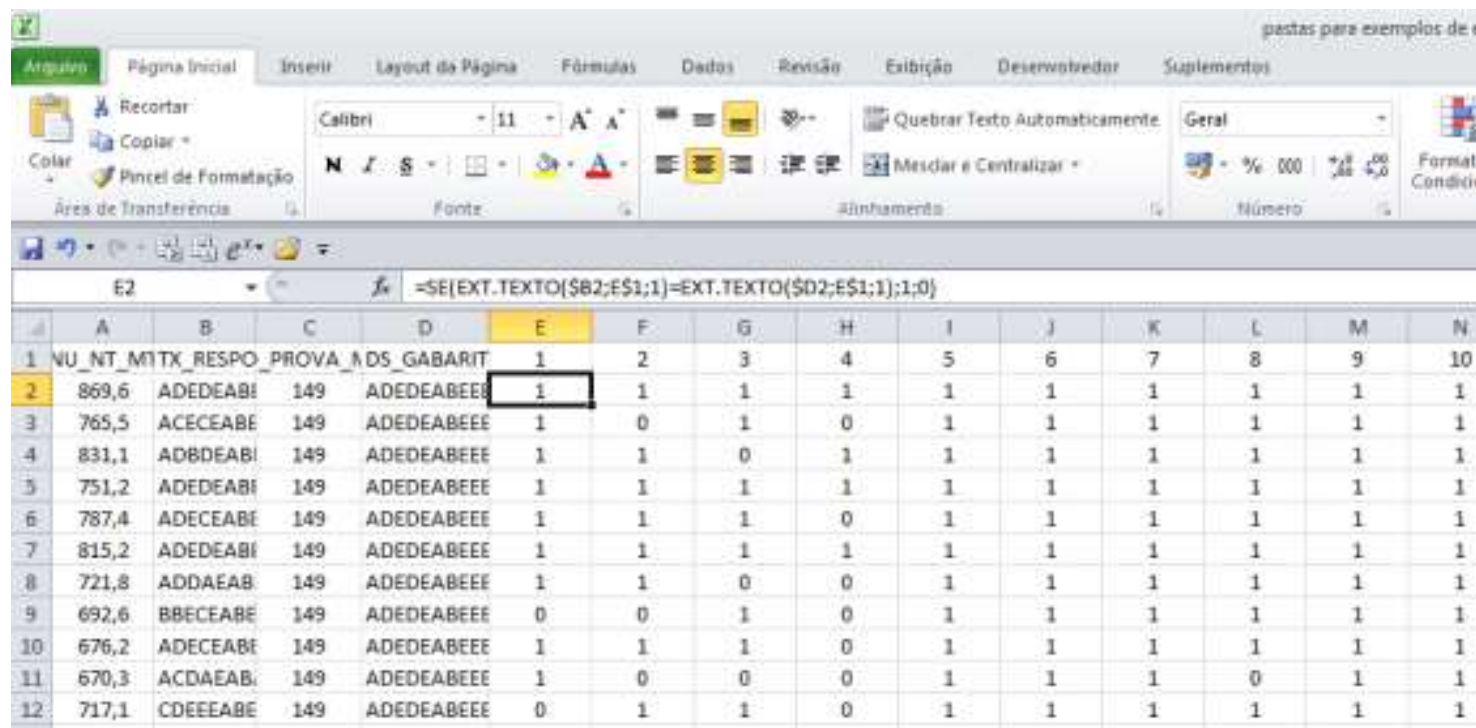

\section{Figura 43 - Acerto ou erro por questão}

A partir daí basta copiar e colar nas células relativas às outras questões e outros alunos.

Se quisermos saber quantas questões cada aluno acertou basta ao final de cada linha aplicar a função SOMA, conforme observamos na figura 44 . No entanto, cuidado para não relacionar o número de acertos com a nota na prova. Já mencionamos este fato por conta da correção utilizar a TRI.

Contudo, vale ressaltar e a diferença entre as notas e o número de acertos. A todo o momento os coordenadores das escolas mostram aos seus alunos a importância de acertar as questões fáceis e médias das provas, com estes resultados ainda não é possível descobrir o que são questões fáceis e médias, mas com certeza é possível mostrar a diferença que existe nas notas até mesmo com o mesmo número de acertos.

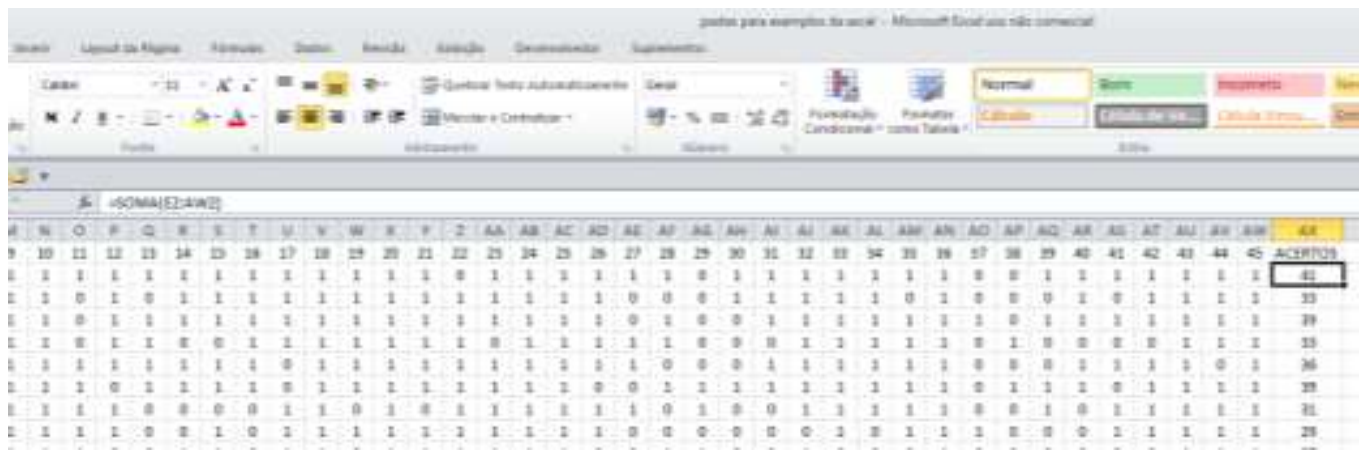

Figura 44 - Total de acertos por área 
Ainda não podemos reconhecer, por exemplo, quantos acertaram o item de código 10547 da prova de matemática, pois, em cada tipo de prova este item aparecia em uma posição, portanto nosso trabalho agora é relacionar o código do item com a identificação da prova e com o número da questão. Este arquivo também foi colocado no link mencionado acima no arquivo: "questões por cor da prova"

A figura 45 mostra algumas questões de matemática na cor amarela (149) e nas outras cores, cinza (150), azul (151) e rosa (152), as questões correspondentes.

\begin{tabular}{|c|c|c|c|c|c|c|c|c|c|c|c|c|c|c|c|}
\hline 149 & 1 & 2 & 3 & 4 & 5 & 6 & 7 & 8 & 9 & 10 & 11 & 12 & 13 & 14 & 15 \\
\hline 150 & 10 & 11 & 12 & 13 & 1 & 2 & 3 & 4 & 5 & 6 & 14 & 15 & 16 & 17 & 34 \\
\hline 151 & 9 & 10 & 11 & 12 & 13 & 14 & 15 & 16 & 20 & 21 & 22 & 23 & 24 & 25 & 5 \\
\hline 152 & 22 & 23 & 24 & 25 & 9 & 10 & 11 & 12 & 16 & 17 & 1 & 2 & 3 & 4 & 18 \\
\hline
\end{tabular}

Figura 45 - Relação entre as questões de cada cor das provas

Uma opção é colocar em ordem as provas por cor, somar os acertos de cada questão relativa a sua cor e depois somar as questões correspondentes.

A outra opção é usar a função SOMASE. Esta função tem o seguinte formato:

=SOMASE(intervalo;critério;[intervalo_soma])

$\mathrm{Na}$ figura 46, na célula E71 inseri a seguinte fórmula:

$=\operatorname{SOMASE}(\$ C \$ 2: \$ C \$ 68 ; \$ D \$ 71 ; \$ E \$ 2: \$ E \$ 68)$

Significa que vou somar os valores da coluna E cujo correspondente na coluna C é o valor 149 (D71), na linha abaixo faço o mesmo em relação à prova cujo número é 150 , e assim por diante. 


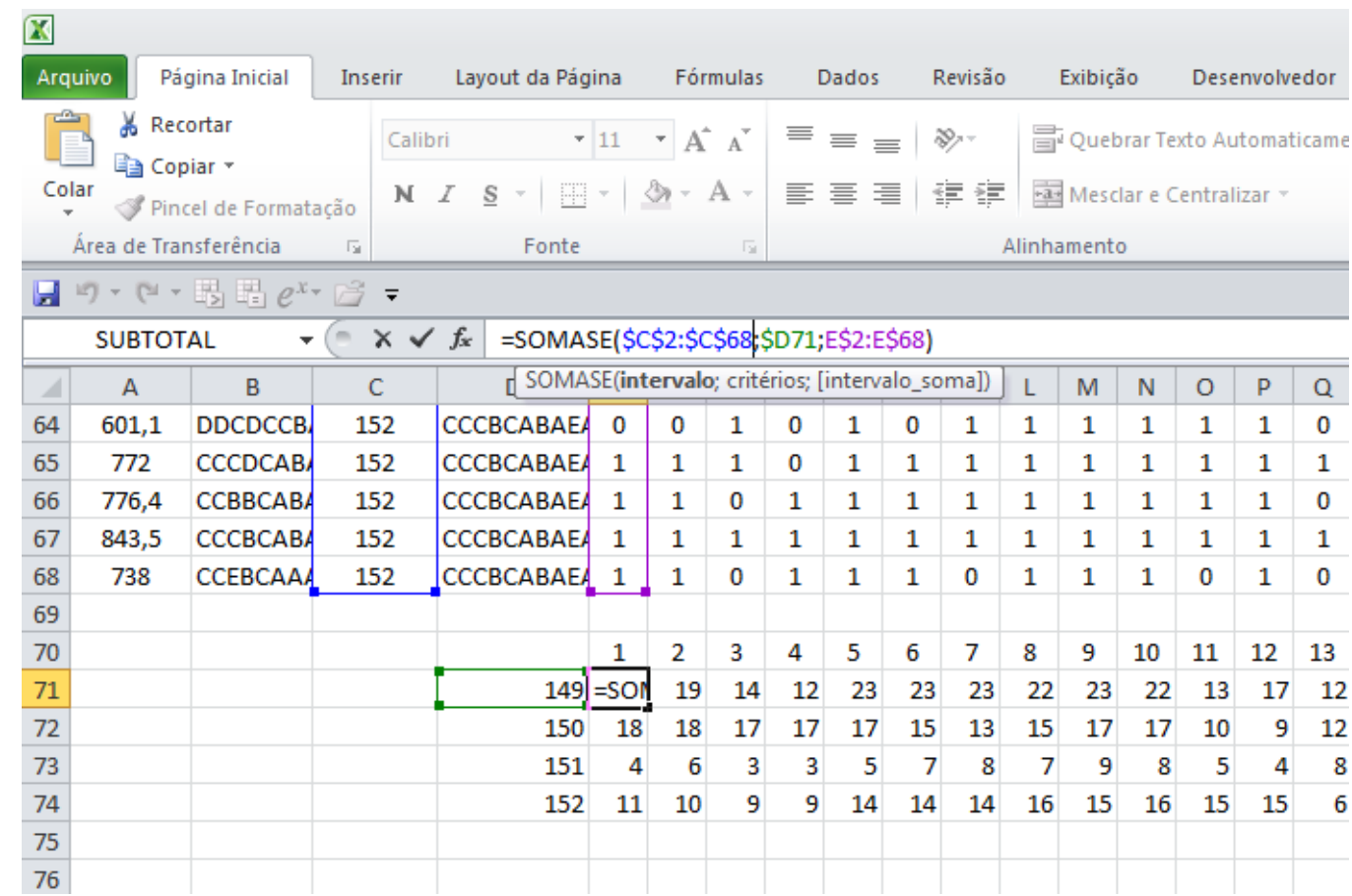

Figura 46 - Soma dos acertos por prova e por questão dos alunos de uma escola

Agora temos que determinar a soma dos acertos da questão 1 na prova 149, da questão 10 na prova 150 , da questão 9 na prova 151 e da questão 22 na prova 152. Para isso vamos usar a função $\mathrm{PROCH}$, que procura um valor na horizontal e depois o correspondente na vertical.

$\mathrm{Na}$ figura 47 temos a soma dos acertos por prova (E70:AW74), em seguida, dividido por cores a relação entre as questões de cada cor de prova e mais abaixo, usando a função PROCH, procuro na matriz E70:AW74, a questão 9 da prova 151, que está na $4^{\mathrm{a}}$ linha. Assim sendo, completo uma nova matriz que somando as colunas encontro o número de acertos por item. 


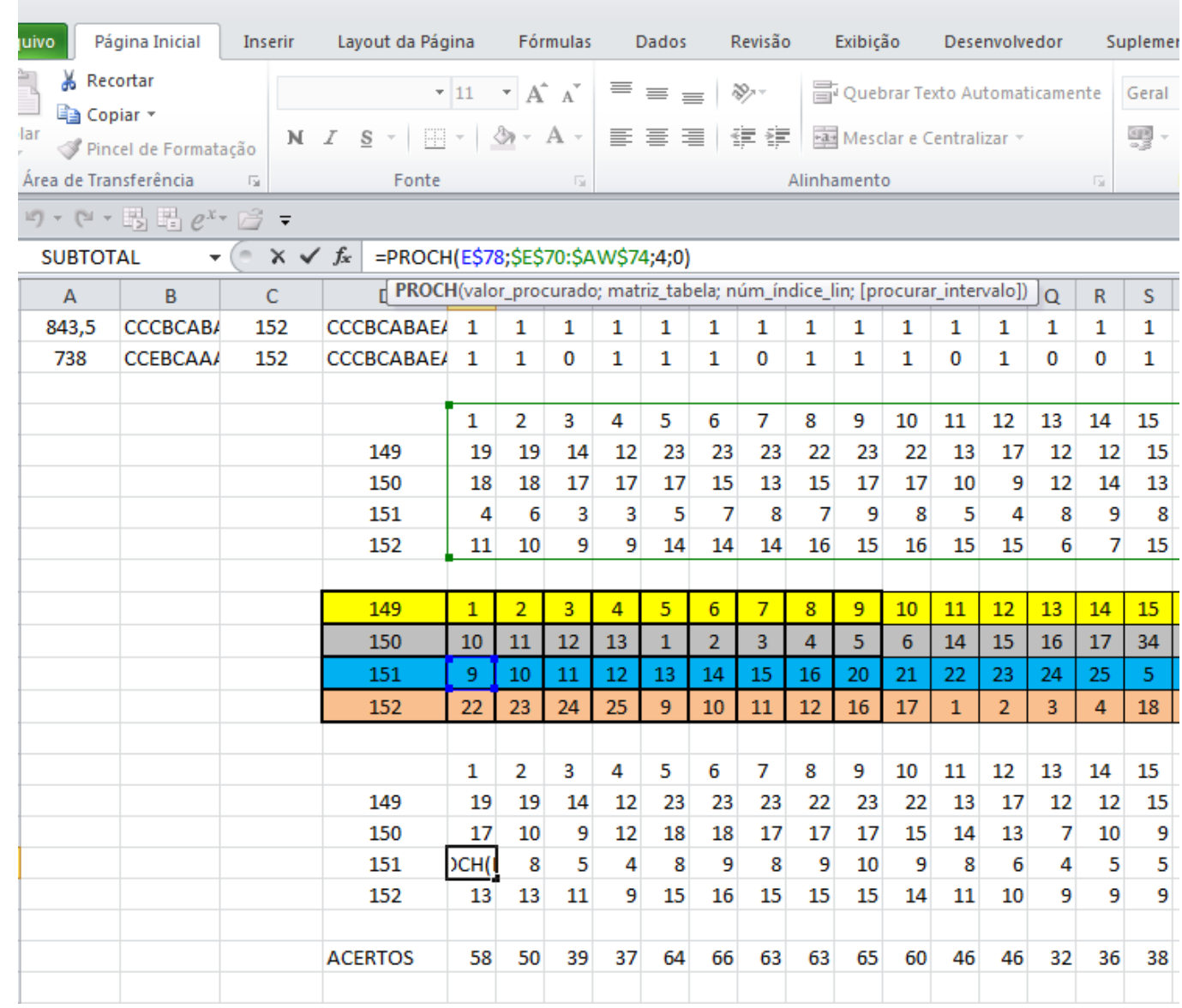

\section{Figura 47 - Acertos por questão}

Finalmente, para calcular o percentual de acertos em cada questão e em cada habilidade, basta dividir os elementos da linha de acertos pelo $\mathrm{n}^{\circ}$ de alunos.

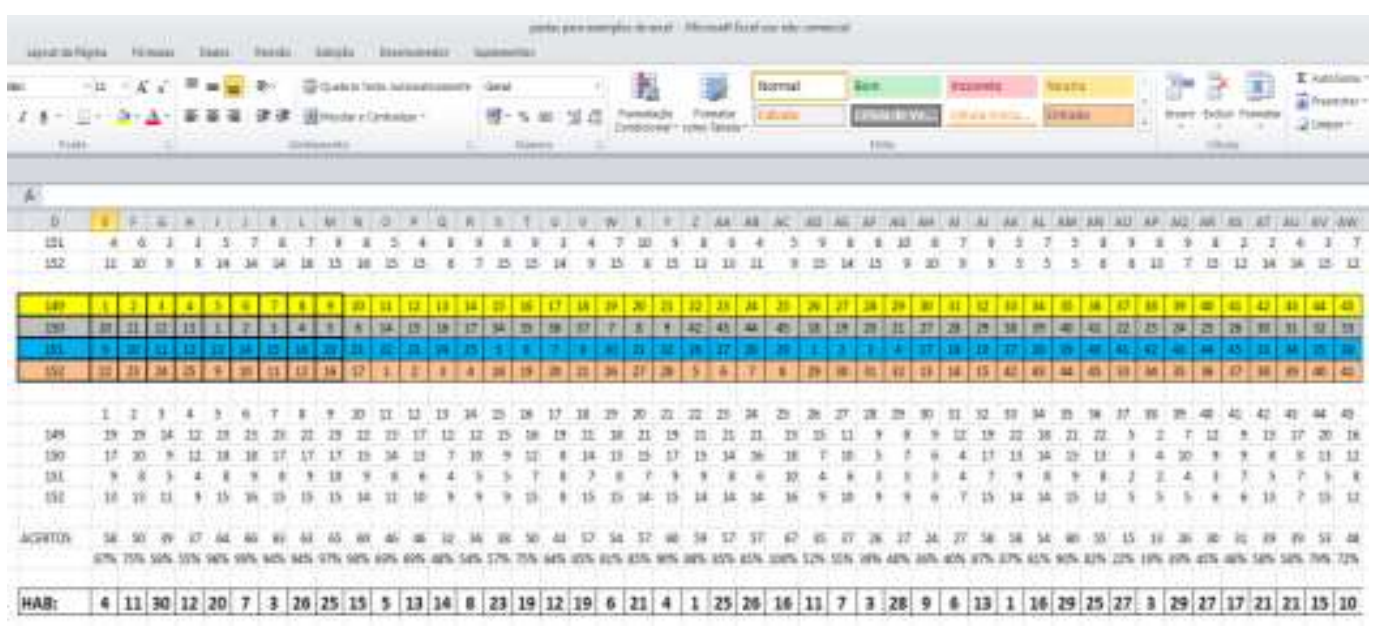

\section{Figura 48 - Percentual de acertos por questão}

Um novo quadro pode ser apresentado levando em conta as habilidades da área de conhecimento (30 no total), o número de vezes em que uma determinada 
habilidade foi inserida na prova e a média de acertos desta habilidade. Tomando o quadro anterior como base, temos:

a)As habilidades possíveis, numeradas de 1 a 30; representada no eixo das abscissas.

b) A Incidência desta habilidade na prova, ou seja, o número de vezes em que a habilidade aparece na prova; representada pelo raio de cada bolha.

c) a Porcentagens de acertos em cada habilidade; representada no eixo das ordenadas.

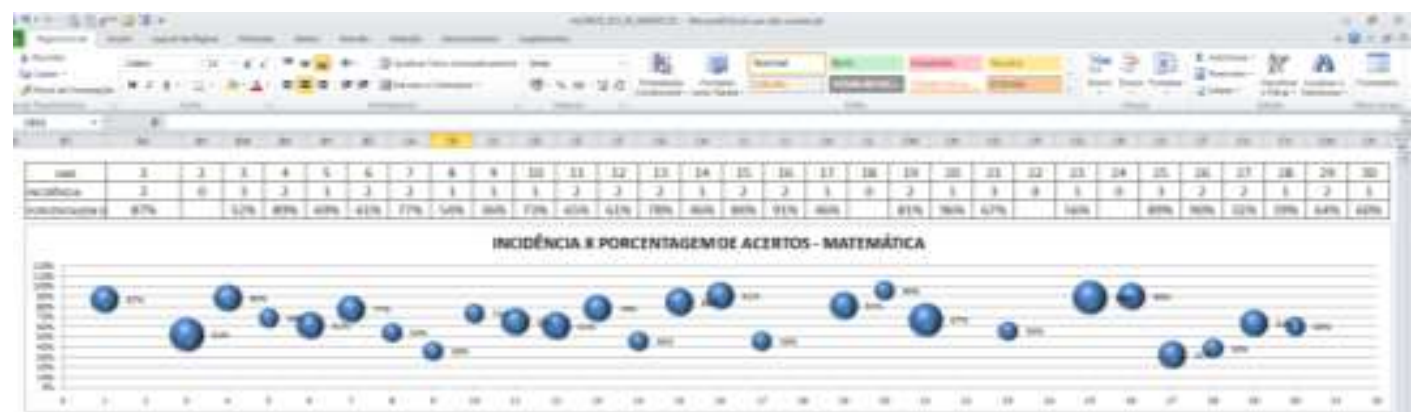

Figura 49 - Tabela e gráfico da média de acertos por habilidade

Este gráfico apresenta como os alunos de determinado colégio se comportaram frente às habilidades apresentadas na prova, por exemplo, a habilidade 27, apareceu 2 vezes na prova e 32\% dos alunos acertaram estas questões, ou seja, quanto maior o diâmetro da bolha maior a incidência na prova e quanto mais alta estiver a bolha maior a porcentagem de acertos, assim a equipe desta escola pode avaliar seus pontos fracos e fortes e em que habilidades devem investir para melhorar o seu rendimento dos seus alunos no ENEM.

Outras tabelas e gráficos podem ser criados e analisados com estes conhecimentos adquiridos neste trecho da pesquisa. Espero ter contribuído para instigar a sede de aprender do leitor. 


\section{Aplicativo}

Como resultado deste trabalho, foi disponibilizado um aplicativo Excel onde ao inserir o código da escola todos os gráficos apresentados no capítulo anterior são gerados automaticamente.

Este aplicativo está no link:

https://drive.google.com/file/d/OByhpXU8vBCVTOS1MeG4zczVObHM/vie $\underline{w}$ ?usp=sharing

A ideia deste trabalho é também incentivar a todos que desejarem aprender uma pouco mais de Excel e se tornarem aptos a desvendar os dados anteriores e posteriores ao ano de 2012 divulgados nos Microdados do ENEM. Com estes conhecimentos é possível construir uma história pedagógica de cada colégio, contribuindo com o seu colégio e com a educação de modo geral, pois quanto mais colégios tiverem estas informações, maior será o passo em direção a melhoria de qualidade do ensino e em consequência do aumento da proficiência do aluno, do aprimoramento do indivíduo e da sua interação na sociedade, que em última análise é o que devemos buscar. 


\section{6 Conclusão}

Pouco se conhece dentro das escolas de modo geral de cada um destes enfoques, apesar do novo ENEM estar estabelecido desde 2009 poucos gestores dominam esta área, seja em relação à TRI, em termos de competências e habilidades, ou até mesmo do significado dos resultados por aluno ou por escola.

O Excel ainda é utilizado apenas como uma simples planilha onde algumas funções são exploradas. Nesta minha pesquisa descobri a fantástica ferramenta que é, ajudando a tomar decisões a partir de suas análises gráficas, de busca de dados com muita velocidade e utilizando de modo inteligente cria em quem a domina um diferencial enorme em relação aos seus pares.

Este trabalho de finalização de curso tem como meta, o de colaborar no aprimoramento do trabalho realizado em cada escola de ensino médio. E para atingi-la a proposta é a de alcançar alguns objetivos que devem ser traçados pelos gestores.

O primeiro objetivo é o de preparar pessoas que dominem ferramentas como internet e o Excel.

O segundo objetivo é o de promover um movimento de time, agregando este profissional à equipe pedagógica, esta dará o norte à pesquisa realizada. Finalmente, feita a pesquisa e levantados os dados, começa o trabalho de divulgação para os professores e alunos dos pontos relevantes desta pesquisa. Assim, cada integrante deste time terá seu espaço para construir seus instrumentos, aplicar seus conhecimentos, avaliar seus resultados e dar feedback para que seja aprimorado o projeto pedagógico da escola.

A definição do formato deste trabalho dá aos diferentes leitores a oportunidade de se dedicar com maior aproveitamento ao assunto que mais the interessa.

Para os ligados à educação, escrevi sobre o ENEM, suas características, seu formato e sobre a TRI. A intensão é a de informar de forma simples o que muitos 
ainda desconhecem e mostrar que ainda temos muito a pesquisar e discutir com os profissionais dos estabelecimentos de ensino.

Em seguida vem a seção onde detalho como obter os microdados, realizar as pesquisas e criar gráficos que auxiliem a análise dos resultados dos alunos de cada estabelecimento, bem como, se assim desejar, comparar seus resultados com os de outros alunos de colégios.

Finalmente, ensino o passo a passo de como construir esta pesquisa, como se fosse um manual técnico, o objetivo é o de estimular os interessados nesta área a pesquisar ferramentas no Excel, criar aplicativos, utilizando também softwares livres, que podem ser distribuídos e compartilhados criando assim, um grupo de profissionais, com conhecimento técnico suficiente dentro das escolas, que auxilie os gestores de estabelecimentos de ensino na busca dos dados dos seus alunos. Esses profissionais também podem, dentro de um nicho ainda pouco explorado, criar e comercializar novos produtos.

Espero ter contribuído com aqueles que gostam de aprender, com os que gostam de ensinar e com os que acima de tudo gostam de criar.

Ao pensar no aplicativo que relato no capítulo anterior não tinha ideia do caminho que deveria traçar, a cada patamar alcançado percebi que tinha aprendido muito e que faltava ainda muito conhecimento, pois imediatamente surgia um novo desafio e mais horas de pesquisa. Ao terminar o aplicativo senti a necessidade de dividir com as pessoas, por isso coloquei na internet, afinal de que adianta criar, pesquisar, aprender e não dividir com o outro este conhecimento. 


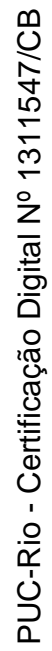




\section{Referência bibliográfica}

[1] Pasquali, L.; Primi, R.. Fundamentos da Teoria da Resposta ao Item - TRI. Avaliação Psicológica, 2003

[2] Andrade, D.F.; Tavares, H.R. \& Valle, R.C. (2001). Teoria da Resposta ao Item: Conceitos e Aplicações. ABE - Associação Brasileira de Estatística, 2000, São Paulo.

[3] Rabelo, M.. Avaliação Educacional: fundamentos, metodologia e aplicações no contexto brasileiro / Mauro Rabelo. Rio de janeiro: SBM, 2013. 268 p.(Coleção PROFMAT; 10)

[4] Rabelo, M. L., Análise Comparativa dos processos de Avaliação Educacional em Larga Escala. II Colóquio de Matemática de Região Centro-Oeste. Universidade Federal do mato Grosso, 2011.

[5] Araujo; E. A. C. , Andrade, D. F., Bortolotti, S. L. V.. Teoria da Resposta ao Item: Introdução à teoria Moderna da Mensuração

[6] Soares, T. M.. Utilização da Teoria da Resposta ao Item na Produção de Indicadores Sócio Econômicos.

[7] Karino, C. A.; Barbosa, M. T. S.. Site do INEP. Nota Técnica - Procedimento de cálculo das notas do ENEM.

[8] Andrade, D.F.; Karino, C. A.. Site do INEP. Nota técnica - Teoria de Resposta ao Item. 


\section{Apêndices}

\subsection{Apêndice 1}

\subsubsection{Matriz de referência}

Eixos Cognitivos do ENEM:

1 - Dominar Linguagens - Dominar a norma culta da língua portuguesa e fazer uso das linguagens matemática, artística e científica e das línguas inglesa e espanhola..

2 - Compreender fenômenos - Construir e aplicar conceitos das várias áreas do conhecimento para a compreensão de fenômenos naturais, de processos históricogeográficos, da produção tecnológica e das manifestações artísticas.

3 - Entender situações-problema - Selecionar, organizar, relacionar, interpretar dados e informações, representados de diferentes formas, para tomar decisões e enfrentar situações-problemas.

4 - Construir Argumentações - Relacionar informações, representadas em diferentes formas, e conhecimentos disponíveis em situações concretas, para construir argumentação consistente.

5 - Elaborar propostas éticas - Recorrer aos conhecimentos desenvolvidos na escola para elaboração de propostas de intervenção solidária na realidade, respeitando os valores humanos e considerando a diversidade sociocultural.

Matriz de Referência de Linguagens, Códigos e suas Tecnologias

Competência de área 1 - Aplicar as tecnologias da comunicação e da informação na escola, no trabalho e em outros contextos relevantes para sua vida.

H1 - Identificar as diferentes linguagens e seus recursos expressivos como elementos de caracterização dos sistemas de comunicação.

$\mathrm{H} 2$ - Recorrer aos conhecimentos sobre as linguagens dos sistemas de comunicação e informação para resolver problemas sociais. 
H3 - Relacionar informações geradas nos sistemas de comunicação e informação, considerando a função social desses sistemas.

H4 - Reconhecer posições críticas aos usos sociais que são feitos das linguagens e dos sistemas de comunicação e informação.

Competência de área 2 - Conhecer e usar língua(s) estrangeira(s) moderna(s) como instrumento de acesso a informações e a outras culturas e grupos sociais.

H5 - Associar vocábulos e expressões de um texto em LEM ao seu tema.

H6 - Utilizar os conhecimentos da LEM e de seus mecanismos como meio de ampliar as possibilidades de acesso a informações, tecnologias e culturas.

H7 - Relacionar um texto em LEM, as estruturas linguísticas, sua função e seu uso social.

H8 - Reconhecer a importância da produção cultural em LEM como representação da diversidade cultural e linguística.

Competência de área 3 - Compreender e usar a linguagem corporal como relevante para a própria vida, integradora social e formadora da identidade.

H9 - Reconhecer as manifestações corporais de movimento como originárias de necessidades cotidianas de um grupo social.

H10 - Reconhecer a necessidade de transformação de hábitos corporais em função das necessidades cinestésicas.

H11 - Reconhecer a linguagem corporal como meio de interação social, considerando os limites de desempenho e as alternativas de adaptação para diferentes indivíduos.

Competência de área 4 - Compreender a arte como saber cultural e estético gerador de significação e integrador da organização do mundo e da própria identidade.

H12 - Reconhecer diferentes funções da arte, do trabalho da produção dos artistas em seus meios culturais.

H13 - Analisar as diversas produções artísticas como meio de explicar diferentes culturas, padrões de beleza e preconceitos.

H14 - Reconhecer o valor da diversidade artística e das interrelações de elementos que se apresentam nas manifestações de vários grupos sociais e étnicos.

Competência de área 5 - Analisar, interpretar e aplicar recursos expressivos das linguagens, relacionando textos com seus contextos, mediante a natureza, 
função, organização e estrutura das manifestações, de acordo com as condições de produção e recepção.

H15 - Estabelecer relações entre o texto literário e o momento de sua produção, situando aspectos do contexto histórico, social e político.

H16 - Relacionar informações sobre concepções artísticas e procedimentos de construção do texto literário.

H17 - Reconhecer a presença de valores sociais e humanos atualizáveis e permanentes no patrimônio literário nacional.

Competência de área 6 - Compreender e usar os sistemas simbólicos das diferentes linguagens como meios de organização cognitiva da realidade pela constituição de significados, expressão, comunicação e informação.

H18 - Identificar os elementos que concorrem para a progressão temática e para a organização e estruturação de textos de diferentes gêneros e tipos.

H19 - Analisar a função da linguagem predominante nos textos em situações específicas de interlocução.

H20 - Reconhecer a importância do patrimônio linguístico para a preservação da memória e da identidade nacional.

Competência de área 7 - Confrontar opiniões e pontos de vista sobre as diferentes linguagens e suas manifestações específicas.

H21 - Reconhecer em textos de diferentes gêneros, recursos verbais e não verbais utilizados com a finalidade de criar e mudar comportamentos e hábitos.

H22 - Relacionar, em diferentes textos, opiniões, temas, assuntos e recursos linguísticos.

H23 - Inferir em um texto quais são os objetivos de seu produtor e quem é seu público-alvo, pela análise dos procedimentos argumentativos utilizados.

H24 - Reconhecer no texto estratégias argumentativas empregadas para o convencimento do público, tais como a intimidação, sedução, comoção, chantagem, entre outras.

Competência de área 8 - Compreender e usar a língua portuguesa como língua materna, geradora de significação e integradora da organização do mundo e da própria identidade.

H25 - Identificar, em textos de diferentes gêneros, as marcas linguísticas que singularizam as variedades linguísticas sociais, regionais e de registro. 
H26 - Relacionar as variedades linguísticas a situações específicas de uso social.

H27 - Reconhecer os usos da norma padrão da língua portuguesa nas diferentes situações de comunicação.

Competência de área 9 - Entender os princípios, a natureza, a função e o impacto das tecnologias da comunicação e da informação na sua vida pessoal e social, no desenvolvimento do conhecimento, associando-os aos conhecimentos científicos, às linguagens que lhes dão suporte, às demais tecnologias, aos processos de produção e aos problemas que se propõem solucionar.

H28 - Reconhecer a função e o impacto social das diferentes tecnologias da comunicação e informação.

H29 - Identificar pela análise de suas linguagens, as tecnologias da comunicação e informação.

H30 - Relacionar as tecnologias da comunicação e informação ao desenvolvimento das sociedades e ao conhecimento que elas produzem.

\begin{tabular}{|c|c|c|c|c|}
\hline \multicolumn{5}{|c|}{ Linguagens, Códigos e suas Tecnologias } \\
\hline Competências & \multicolumn{4}{|c|}{ Habilidades por competência } \\
\hline $\mathrm{C}_{1}$ & $\mathrm{H} 1$ & $\mathrm{H} 2$ & $\mathrm{H} 3$ & $\mathrm{H} 4$ \\
\hline $\mathrm{C}_{2}$ & $\mathrm{H} 5$ & $\mathrm{H} 6$ & $\mathrm{H} 7$ & $\mathrm{H} 8$ \\
\hline $\mathrm{C}_{3}$ & $\mathrm{H} 9$ & $\mathrm{H} 10$ & $\mathrm{H} 11$ & \\
\hline $\mathrm{C}_{4}$ & $\mathrm{H} 12$ & $\mathrm{H} 13$ & $\mathrm{H} 14$ & \\
\hline $\mathrm{C}_{5}$ & $\mathrm{H} 15$ & $\mathrm{H} 16$ & $\mathrm{H} 17$ & \\
\hline $\mathrm{C}_{6}$ & $\mathrm{H} 18$ & $\mathrm{H} 19$ & $\mathrm{H} 20$ & \\
\hline $\mathrm{C}_{7}$ & $\mathrm{H} 21$ & $\mathrm{H} 22$ & $\mathrm{H} 23$ & $\mathrm{H} 24$ \\
\hline $\mathrm{C}_{8}$ & $\mathrm{H} 25$ & $\mathrm{H} 26$ & $\mathrm{H} 27$ & \\
\hline $\mathrm{C}_{9}$ & $\mathrm{H} 28$ & $\mathrm{H} 29$ & $\mathrm{H} 30$ & \\
\hline
\end{tabular}

Matriz de Referência de Matemática e suas Tecnologias

Competência de área 1 - Construir significados para os números naturais, inteiros, racionais e reais.

H1 - Reconhecer, no contexto social, diferentes significados e representações dos números e operações - naturais, inteiros, racionais ou reais. 
H2 - Identificar padrões numéricos ou princípios de contagem.

H3 - Resolver situação-problema envolvendo conhecimentos numéricos.

H4 - Avaliar a razoabilidade de um resultado numérico na construção de argumentos sobre afirmações quantitativas.

H5 - Avaliar propostas de intervenção na realidade utilizando conhecimentos numéricos.

Competência de área 2 - Utilizar o conhecimento geométrico para realizar a leitura e a representação da realidade e agir sobre ela.

H6 - Interpretar a localização e a movimentação de pessoas/objetos no espaço tridimensional e sua representação no espaço bidimensional.

H7 - Identificar características de figuras planas ou espaciais.

H8 - Resolver situação-problema que envolva conhecimentos geométricos de espaço e forma.

H9 - Utilizar conhecimentos geométricos de espaço e forma na seleção de argumentos propostos como solução de problemas do cotidiano.

Competência de área 3 - Construir noções de grandezas e medidas para a compreensão da realidade e a solução de problemas do cotidiano.

H10 - Identificar relações entre grandezas e unidades de medida.

H11 - Utilizar a noção de escalas na leitura de representação de situação do cotidiano.

H12 - Resolver situação-problema que envolva medidas de grandezas.

H13 - Avaliar o resultado de uma medição na construção de um argumento consistente.

H14 - Avaliar proposta de intervenção na realidade utilizando conhecimentos geométricos relacionados a grandezas e medidas.

Competência de área 4 - Construir noções de variação de grandezas para a compreensão da realidade e a solução de problemas do cotidiano.

H15 - Identificar a relação de dependência entre grandezas.

H16 - Resolver situação-problema envolvendo a variação de grandezas, direta ou inversamente proporcionais.

H17 - Analisar informações envolvendo a variação de grandezas como recurso para a construção de argumentação.

H18 - Avaliar propostas de intervenção na realidade envolvendo variação de grandezas. 
Competência de área 5 - Modelar e resolver problemas que envolvem variáveis

socioeconômicas ou técnico-científicas, usando representações algébricas.

H19 - Identificar representações algébricas que expressem a relação entre grandezas.

H20 - Interpretar gráfico cartesiano que represente relações entre grandezas.

H21 - Resolver situação-problema cuja modelagem envolva conhecimentos algébricos.

H22 - Utilizar conhecimentos algébricos/geométricos como recurso para a construção de argumentação.

H23 - Avaliar propostas de intervenção na realidade utilizando conhecimentos algébricos.

Competência de área 6 - Interpretar informações de natureza científica e social obtidas da leitura de gráficos e tabelas, realizando previsão de tendência, extrapolação, interpolação e interpretação.

H24 - Utilizar informações expressas em gráficos ou tabelas para fazer inferências.

H25 - Resolver problema com dados apresentados em tabelas ou gráficos.

H26 - Analisar informações expressas em gráficos ou tabelas como recurso para a construção de argumentos.

Competência de área 7 - Compreender o caráter aleatório e não determinístico dos fenômenos naturais e sociais e utilizar instrumentos adequados para medidas, determinação de amostras e cálculos de probabilidade para interpretar informações de variáveis apresentadas em uma distribuição estatística.

H27 - Calcular medidas de tendência central ou de dispersão de um conjunto de dados expressos em uma tabela de frequências de dados agrupados (não em classes) ou em gráficos.

H28 - Resolver situação-problema que envolva conhecimentos de estatística e probabilidade.

H29 - Utilizar conhecimentos de estatística e probabilidade como recurso para a construção de argumentação.

H30 - Avaliar propostas de intervenção na realidade utilizando conhecimentos de estatística e probabilidade. 


\begin{tabular}{|c|c|c|c|c|c|}
\hline \multicolumn{6}{|c|}{ Matemática e suas Tecnologias } \\
\hline Competências & \multicolumn{5}{|c|}{ Habilidades por competência } \\
\hline $\mathrm{C}_{1}$ & $\mathrm{H} 1$ & $\mathrm{H} 2$ & $\mathrm{H} 3$ & $\mathrm{H} 4$ & $\mathrm{H} 5$ \\
\hline $\mathrm{C}_{2}$ & $\mathrm{H} 6$ & $\mathrm{H} 7$ & $\mathrm{H} 8$ & $\mathrm{H} 9$ & \\
\hline $\mathrm{C}_{3}$ & $\mathrm{H} 10$ & $\mathrm{H} 11$ & $\mathrm{H} 12$ & $\mathrm{H} 13$ & $\mathrm{H} 14$ \\
\hline $\mathrm{C}_{4}$ & $\mathrm{H} 15$ & $\mathrm{H} 16$ & $\mathrm{H} 17$ & $\mathrm{H} 18$ & \\
\hline $\mathrm{C}_{5}$ & $\mathrm{H} 19$ & $\mathrm{H} 20$ & $\mathrm{H} 21$ & $\mathrm{H} 22$ & $\mathrm{H} 23$ \\
\hline $\mathrm{C}_{6}$ & $\mathrm{H} 24$ & $\mathrm{H} 25$ & $\mathrm{H} 26$ & & \\
\hline $\mathrm{C}_{7}$ & $\mathrm{H} 27$ & $\mathrm{H} 28$ & $\mathrm{H} 29$ & $\mathrm{H} 30$ & \\
\hline
\end{tabular}

Matriz de Referência de Ciências da Natureza e suas Tecnologias

Competência de área 1 - Compreender as ciências naturais e as tecnologias a elas associadas como construções humanas, percebendo seus papéis nos processos de produção e no desenvolvimento econômico e social da humanidade.

H1 - Reconhecer características ou propriedades de fenômenos ondulatórios ou oscilatórios, relacionando-os a seus usos em diferentes contextos.

H2 - Associar a solução de problemas de comunicação, transporte, saúde ou outro com o correspondente desenvolvimento científico e tecnológico.

H3 - Confrontar interpretações científicas com interpretações baseadas no senso comum, ao longo do tempo ou em diferentes culturas.

H4 - Avaliar propostas de intervenção no ambiente, considerando a qualidade da vida humana ou medidas de conservação, recuperação ou utilização sustentável da biodiversidade.

Competência de área 2 - Identificar a presença e aplicar as tecnologias associadas às ciências naturais em diferentes contextos.

H5 - Dimensionar circuitos ou dispositivos elétricos de uso cotidiano.

H6 - Relacionar informações para compreender manuais de instalação ou utilização de aparelhos, ou sistemas tecnológicos de uso comum.

H7 - Selecionar testes de controle, parâmetros ou critérios para a comparação de materiais e produtos, tendo em vista a defesa do consumidor, a saúde do trabalhador ou a qualidade de vida. 
Competência de área 3 - Associar intervenções que resultam em degradação ou conservação ambiental a processos produtivos e sociais e a instrumentos ou ações científico-tecnológicos.

H8 - Identificar etapas em processos de obtenção, transformação, utilização ou reciclagem de recursos naturais, energéticos ou matérias-primas, considerando processos biológicos, químicos ou físicos neles envolvidos.

H9 - Compreender a importância dos ciclos biogeoquímicos ou do fluxo de energia para a vida, ou da ação de agentes ou fenômenos que podem causar alterações nesses processos.

H10 - Analisar perturbações ambientais, identificando fontes, transporte e/ou destino dos poluentes ou prevendo efeitos em sistemas naturais, produtivos ou sociais.

H11 - Reconhecer benefícios, limitações e aspectos éticos da biotecnologia, considerando estruturas e processos biológicos envolvidos em produtos biotecnológicos.

H12 - Avaliar impactos em ambientes naturais decorrentes de atividades sociais ou econômicas, considerando interesses contraditórios.

Competência de área 4 - Compreender interações entre organismos e ambiente, em particular aquelas relacionadas à saúde humana, relacionando conhecimentos científicos, aspectos culturais e características individuais.

H13 - Reconhecer mecanismos de transmissão da vida, prevendo ou explicando a manifestação de características dos seres vivos.

H14 - Identificar padrões em fenômenos e processos vitais dos organismos, como manutenção do equilíbrio interno, defesa, relações com o ambiente, sexualidade, entre outros.

H15 - Interpretar modelos e experimentos para explicar fenômenos ou processos biológicos em qualquer nível de organização dos sistemas biológicos.

H16 - Compreender o papel da evolução na produção de padrões e processos biológicos ou na organização taxonômica dos seres vivos.

Competência de área 5 - Entender métodos e procedimentos próprios das ciências naturais e aplicá-los em diferentes contextos.

H17 - Relacionar informações apresentadas em diferentes formas de linguagem e representação usadas nas ciências físicas, químicas ou biológicas, 
como texto discursivo, gráficos, tabelas, relações matemáticas ou linguagem simbólica.

H18 - Relacionar propriedades físicas, químicas ou biológicas de produtos, sistemas ou procedimentos tecnológicos às finalidades a que se destinam.

H19 - Avaliar métodos, processos ou procedimentos das ciências naturais que contribuam para diagnosticar ou solucionar problemas de ordem social, econômica ou ambiental.

Competência de área 6 - Apropriar-se de conhecimentos da física para, em situaçõesproblema, interpretar, avaliar ou planejar intervenções científicotecnológicas.

H20 - Caracterizar causas ou efeitos dos movimentos de partículas, substâncias, objetos ou corpos celestes.

H21 - Utilizar leis físicas e/ou químicas para interpretar processos naturais ou tecnológicos inseridos no contexto da termodinâmica e/ou do eletromagnetismo.

H22 - Compreender fenômenos decorrentes da interação entre a radiação e a matéria em suas manifestações em processos naturais ou tecnológicos, ou em suas implicações biológicas, sociais, econômicas ou ambientais.

H23 - Avaliar possibilidades de geração, uso ou transformação de energia em ambientes específicos, considerando implicações éticas, ambientais, sociais e/ou econômicas.

Competência de área 7 - Apropriar-se de conhecimentos da química para, em situaçõesproblema, interpretar, avaliar ou planejar intervenções científicotecnológicas.

H24 - Utilizar códigos e nomenclatura da química para caracterizar materiais, substâncias ou transformações químicas.

H25 - Caracterizar materiais ou substâncias, identificando etapas, rendimentos ou implicações biológicas, sociais, econômicas ou ambientais de sua obtenção ou produção.

H26 - Avaliar implicações sociais, ambientais e/ou econômicas na produção ou no consumo de recursos energéticos ou minerais, identificando transformações químicas ou de energia envolvidas nesses processos.

H27 - Avaliar propostas de intervenção no meio ambiente aplicando conhecimentos químicos, observando riscos ou benefícios. 
Competência de área 8 - Apropriar-se de conhecimentos da biologia para, em situaçõesproblema, interpretar, avaliar ou planejar intervenções científicotecnológicas.

H28 - Associar características adaptativas dos organismos com seu modo de vida ou com seus limites de distribuição em diferentes ambientes, em especial em ambientes brasileiros.

H29 - Interpretar experimentos ou técnicas que utilizam seres vivos, analisando implicações para o ambiente, a saúde, a produção de alimentos, matérias-primas ou produtos industriais.

H30 - Avaliar propostas de alcance individual ou coletivo, identificando aquelas que visam à preservação e à implementação da saúde individual, coletiva ou do ambiente.

\begin{tabular}{|c|c|c|c|c|c|}
\hline \multicolumn{6}{|c|}{ Ciências da Natureza e suas Tecnologias } \\
\hline Competências & \multicolumn{5}{|c|}{ Habilidades por competência } \\
\hline $\mathrm{C}_{1}$ & $\mathrm{H} 1$ & $\mathrm{H} 2$ & H3 & $\mathrm{H} 4$ & \\
\hline $\mathrm{C}_{2}$ & H5 & $\mathrm{H} 6$ & $\mathrm{H} 7$ & & \\
\hline $\mathrm{C}_{3}$ & $\mathrm{H} 8$ & $\mathrm{H} 9$ & $\mathrm{H} 10$ & $\mathrm{H} 11$ & $\mathrm{H} 12$ \\
\hline $\mathrm{C}_{4}$ & $\mathrm{H} 13$ & $\mathrm{H} 14$ & $\mathrm{H} 15$ & $\mathrm{H} 16$ & \\
\hline $\mathrm{C}_{5}$ & $\mathrm{H} 17$ & $\mathrm{H} 18$ & H19 & & \\
\hline $\mathrm{C}_{6}$ & $\mathrm{H} 20$ & $\mathrm{H} 21$ & $\mathrm{H} 22$ & $\mathrm{H} 23$ & \\
\hline $\mathrm{C}_{7}$ & $\mathrm{H} 24$ & $\mathrm{H} 25$ & $\mathrm{H} 26$ & $\mathrm{H} 27$ & \\
\hline $\mathrm{C}_{8}$ & $\mathrm{H} 28$ & $\mathrm{H} 29$ & $\mathrm{H} 30$ & & \\
\hline
\end{tabular}

Matriz de Referência de Ciências Humanas e suas Tecnologias

Competência de área 1 - Compreender os elementos culturais que constituem as identidades.

H1 - Interpretar historicamente e/ou geograficamente fontes documentais acerca de aspectos da cultura.

H2 - Analisar a produção da memória pelas sociedades humanas.

H3 - Associar as manifestações culturais do presente aos seus processos históricos.

H4 - Comparar pontos de vista expressos em diferentes fontes sobre determinado aspecto da cultura. 
H5 - Identificar as manifestações ou representações da diversidade do patrimônio cultural e artístico em diferentes sociedades.

Competência de área 2 - Compreender as transformações dos espaços geográficos como produto das relações socioeconômicas e culturais de poder.

H6 - Interpretar diferentes representações gráficas e cartográficas dos espaços geográficos.

H7 - Identificar os significados histórico-geográficos das relações de poder entre as nações.

H8 - Analisar a ação dos estados nacionais no que se refere à dinâmica dos fluxos populacionais e no enfrentamento de problemas de ordem econômicosocial.

H9 - Comparar o significado histórico-geográfico das organizações políticas e socioeconômicas em escala local, regional ou mundial.

H10 - Reconhecer a dinâmica da organização dos movimentos sociais e a importância da participação da coletividade na transformação da realidade histórico-geográfica.

Competência de área 3 - Compreender a produção e o papel histórico das instituições sociais, políticas e econômicas, associando-as aos diferentes grupos, conflitos e movimentos sociais.

H11 - Identificar registros de práticas de grupos sociais no tempo e no espaço.

H12 - Analisar o papel da justiça como instituição na organização das sociedades.

H13 - Analisar a atuação dos movimentos sociais que contribuíram para mudanças ou rupturas em processos de disputa pelo poder.

H14 - Comparar diferentes pontos de vista, presentes em textos analíticos e interpretativos, sobre situação ou fatos de natureza histórico-geográfica acerca das instituições sociais, políticas e econômicas.

H15 - Avaliar criticamente conflitos culturais, sociais, políticos, econômicos ou ambientais ao longo da história.

Competência de área 4 - Entender as transformações técnicas e tecnológicas e seu impacto nos processos de produção, no desenvolvimento do conhecimento e na vida social. 
H16 - Identificar registros sobre o papel das técnicas e tecnologias na organização do trabalho e/ou da vida social.

H17 - Analisar fatores que explicam o impacto das novas tecnologias no processo de territorialização da produção.

H18 - Analisar diferentes processos de produção ou circulação de riquezas e suas implicações socioespaciais.

H19 - Reconhecer as transformações técnicas e tecnológicas que determinam as várias formas de uso e apropriação dos espaços rural e urbano.

H20 - Selecionar argumentos favoráveis ou contrários às modificações impostas pelas novas tecnologias à vida social e ao mundo do trabalho.

Competência de área 5 - Utilizar os conhecimentos históricos para compreender e valorizar os fundamentos da cidadania e da democracia, favorecendo uma atuação consciente do indivíduo na sociedade.

H21 - Identificar o papel dos meios de comunicação na construção da vida social.

H22 - Analisar as lutas sociais e conquistas obtidas no que se refere às mudanças nas legislações ou nas políticas públicas.

H23 - Analisar a importância dos valores éticos na estruturação política das sociedades.

H24 - Relacionar cidadania e democracia na organização das sociedades.

H25 - Identificar estratégias que promovam formas de inclusão social.

Competência de área 6 - Compreender a sociedade e a natureza, reconhecendo suas interações no espaço em diferentes contextos históricos e geográficos.

H26 - Identificar em fontes diversas o processo de ocupação dos meios físicos e as relações da vida humana com a paisagem.

H27 - Analisar de maneira crítica as interações da sociedade com o meio físico, levando em consideração aspectos históricos e/ou geográficos.

H28 - Relacionar o uso das tecnologias com os impactos socioambientais em diferentes contextos histórico-geográficos.

H29 - Reconhecer a função dos recursos naturais na produção do espaço geográfico, relacionando-os com as mudanças provocadas pelas ações humanas.

H30 - Avaliar as relações entre preservação e degradação da vida no planeta nas diferentes escalas. 


\begin{tabular}{|c|c|c|c|c|c|}
\hline \multicolumn{5}{|c|}{ Ciências Humanas e suas Tecnologias } \\
\hline Competências & \multicolumn{5}{|c|}{ Habilidades por competência } \\
\hline $\mathrm{C}_{1}$ & $\mathrm{H} 1$ & $\mathrm{H} 2$ & $\mathrm{H} 3$ & $\mathrm{H} 4$ & $\mathrm{H} 5$ \\
\hline $\mathrm{C}_{2}$ & $\mathrm{H} 6$ & $\mathrm{H} 7$ & $\mathrm{H} 8$ & $\mathrm{H} 9$ & $\mathrm{H} 10$ \\
\hline $\mathrm{C}_{3}$ & $\mathrm{H} 11$ & $\mathrm{H} 12$ & $\mathrm{H} 13$ & $\mathrm{H} 14$ & $\mathrm{H} 15$ \\
\hline $\mathrm{C}_{4}$ & $\mathrm{H} 16$ & $\mathrm{H} 17$ & $\mathrm{H} 18$ & $\mathrm{H} 19$ & $\mathrm{H} 20$ \\
\hline $\mathrm{C}_{5}$ & $\mathrm{H} 21$ & $\mathrm{H} 22$ & $\mathrm{H} 23$ & $\mathrm{H} 24$ & $\mathrm{H} 25$ \\
\hline $\mathrm{C}_{6}$ & $\mathrm{H} 26$ & $\mathrm{H} 27$ & $\mathrm{H} 28$ & $\mathrm{H} 29$ & $\mathrm{H} 30$ \\
\hline
\end{tabular}

Objetos de conhecimento associados às Matrizes de Referência

1. Linguagens, Códigos e suas Tecnologias

- Estudo do texto: as sequências discursivas e os gêneros textuais no sistema de comunicação e informação - modos de organização da composição textual; atividades de produção escrita e de leitura de textos gerados nas diferentes esferas sociais - públicas e privadas.

- Estudo das práticas corporais: a linguagem corporal como integradora social e formadora de identidade - performance corporal e identidades juvenis; possibilidades de vivência crítica e emancipada do lazer; mitos e verdades sobre os corpos masculino e feminino na sociedade atual; exercício físico e saúde; o corpo e a expressão artística e cultural; o corpo no mundo dos símbolos e como produção da cultura; práticas corporais e autonomia; condicionamentos e esforços físicos; o esporte; a dança; as lutas; os jogos; as brincadeiras.

- Produção e recepção de textos artísticos: interpretação e representação do mundo para o fortalecimento dos processos de identidade e cidadania - Artes Visuais: estrutura morfológica, sintática, o contexto da obra artística, o contexto da comunidade. Teatro: estrutura morfológica, sintática, o contexto da obra artística, o contexto da comunidade, as fontes de criação. Música: estrutura morfológica, sintática, o contexto da obra artística, o contexto da comunidade, as fontes de criação. Dança: estrutura morfológica, sintática, o contexto da obra artística, o contexto da comunidade, as fontes de criação. Conteúdos estruturantes das linguagens artísticas (Artes Visuais, Dança, Música, Teatro), elaborados a 
partir de suas estruturas morfológicas e sintáticas; inclusão, diversidade e multiculturalidade: a valorização da pluralidade expressada nas produções estéticas e artísticas das minorias sociais e dos portadores de necessidades especiais educacionais.

- Estudo do texto literário: relações entre produção literária e processo social, concepções artísticas, procedimentos de construção e recepção de textos produção literária e processo social; processos de formação literária e de formação nacional; produção de textos literários, sua recepção e a constituição do patrimônio literário nacional; relações entre a dialética cosmopolitismo/localismo e a produção literária nacional; elementos de continuidade e ruptura entre os diversos momentos da literatura brasileira; associações entre concepções artísticas e procedimentos de construção do texto literário em seus gêneros (épico/narrativo, lírico e dramático) e formas diversas; articulações entre os recursos expressivos e estruturais do texto literário e o processo social relacionado ao momento de sua produção; representação literária: natureza, função, organização e estrutura do texto literário; relações entre literatura, outras artes e outros saberes.

- Estudo dos aspectos linguísticos em diferentes textos: recursos expressivos da língua, procedimentos de construção e recepção de textos - organização da macroestrutura semântica e a articulação entre idéias e proposições (relações lógico-semânticas).

- Estudo do texto argumentativo, seus gêneros e recursos linguísticos: argumentação: tipo, gêneros e usos em língua portuguesa - formas de apresentação de diferentes pontos de vista; organização e progressão textual; papéis sociais e comunicativos dos interlocutores, relação entre usos e propósitos comunicativos, função sociocomunicativa do gênero, aspectos da dimensão espaço-temporal em que se produz o texto.

- Estudo dos aspectos linguísticos da língua portuguesa: usos da língua: norma culta e variação linguística - uso dos recursos linguísticos em relação ao contexto em que o texto é constituído: elementos de referência pessoal, temporal, espacial, registro linguístico, grau de formalidade, seleção lexical, tempos e modos verbais; uso dos recursos linguísticos em processo de coesão textual: elementos de articulação das sequências dos textos ou a construção da microestrutura do texto. 
- Estudo dos gêneros digitais: tecnologia da comunicação e informação: impacto e funçãosocial - o texto literário típico da cultura de massa: o suporte textual em gêneros digitais; a caracterização dos interlocutores na comunicação tecnológica; os recursos linguísticos e os gêneros digitais; a função social das novas tecnologias.

\section{Matemática e suas Tecnologias}

- Conhecimentos numéricos - operações em conjuntos numéricos (naturais, inteiros, racionais e reais), desigualdades, divisibilidade, fatoração, razões e proporções, porcentagem e juros, relações de dependência entre grandezas, sequências e progressões, princípios de contagem.

- Conhecimentos geométricos - características das figuras geométricas planas e espaciais; grandezas, unidades de medida e escalas; comprimentos, áreas e volumes; ângulos; posições de retas; simetrias de figuras planas ou espaciais; congruência e semelhança de triângulos; teorema de Tales; relações métricas nos triângulos; circunferências; trigonometria do ângulo agudo.

- Conhecimentos de estatística e probabilidade - representação e análise de dados; medidas de tendência central (médias, moda e mediana); desvios e variância; noções de probabilidade.

- Conhecimentos algébricos - gráficos e funções; funções algébricas do $1 .^{\circ} \mathrm{e}$ do 2. ${ }^{\circ}$ graus, polinomiais, racionais, exponenciais e logarítmicas; equações e inequações; relações no ciclo trigonométrico e funções trigonométricas.

- Conhecimentos algébricos/geométricos - plano cartesiano; retas; circunferências; paralelismo e perpendicularidade, sistemas de equações.

\section{Ciências da Natureza e suas Tecnologias}

\subsection{Física}

- Conhecimentos básicos e fundamentais - Noções de ordem de grandeza. Notação Científica.

Sistema Internacional de Unidades. Metodologia de investigação: a procura de regularidades e de sinais na interpretação física do mundo. Observações e mensurações: representação de grandezas físicas como grandezas mensuráveis. Ferramentas básicas: gráficos e vetores. Conceituação de grandezas vetoriais e escalares. Operações básicas com vetores. 
- O movimento, o equilíbrio e a descoberta de leis físicas - Grandezas fundamentais da mecânica: tempo, espaço, velocidade e aceleração. Relação histórica entre força e movimento. Descrições do movimento e sua interpretação: quantificação do movimento e sua descrição matemática e gráfica.

Casos especiais de movimentos e suas regularidades observáveis. Conceito de inércia. Noção de sistemas de referência inerciais e não inerciais. Noção dinâmica de massa e quantidade de movimento (momento linear). Força e variação da quantidade de movimento. Leis de Newton.

Centro de massa e a idéia de ponto material. Conceito de forças externas e internas. Lei da conservação da quantidade de movimento (momento linear) e teorema do impulso. Momento de uma força (torque). Condições de equilíbrio estático de ponto material e de corpos rígidos. Força de atrito, força peso, força normal de contato e tração. Diagramas de forças. Identificação das forças que atuam nos movimentos circulares. Noção de força centrípeta e sua quantificação. A hidrostática: aspectos históricos e variáveis relevantes. Empuxo. Princípios de Pascal, Arquimedes e Stevin: condições de flutuação, relação entre diferença de nível e pressão hidrostática.

- Energia, trabalho e potência - Conceituação de trabalho, energia e potência. Conceito de energia potencial e de energia cinética. Conservação de energia mecânica e dissipação de energia. Trabalho da força gravitacional e energia potencial gravitacional. Forças conservativas e dissipativas.

- A mecânica e o funcionamento do universo - Força peso. Aceleração gravitacional. Lei da Gravitação Universal. Leis de Kepler. Movimentos de corpos celestes. Influência na Terra: marés e variações climáticas. Concepções históricas sobre a origem do universo e sua evolução.

- Fenômenos elétricos e magnéticos - Carga elétrica e corrente elétrica. Lei de Coulomb. Campo elétrico e potencial elétrico. Linhas de campo. Superfícies equipotenciais. Poder das pontas.

Blindagem. Capacitores. Efeito Joule. Lei de Ohm. Resistência elétrica e resistividade. Relações entre grandezas elétricas: tensão, corrente, potência e energia. Circuitos elétricos simples. Correntes contínua e alternada. Medidores elétricos. Representação gráfica de circuitos. Símbolos convencionais. Potência e consumo de energia em dispositivos elétricos. Campo magnético. Imãs permanentes. Linhas de campo magnético. Campo magnético terrestre. 
- Oscilações, ondas, óptica e radiação - Feixes e frentes de ondas. Reflexão e refração. Óptica geométrica: lentes e espelhos. Formação de imagens. Instrumentos ópticos simples. Fenômenos ondulatórios. Pulsos e ondas. Período, frequência, ciclo. Propagação: relação entre velocidade, frequência e comprimento de onda. Ondas em diferentes meios de propagação.

- O calor e os fenômenos térmicos - Conceitos de calor e de temperatura. Escalas termométricas.

Transferência de calor e equilíbrio térmico. Capacidade calorífica e calor específico. Condução do calor. Dilatação térmica. Mudanças de estado físico e calor latente de transformação.

Comportamento de gases ideais. Máquinas térmicas. Ciclo de Carnot. Leis da Termodinâmica.

Aplicações e fenômenos térmicos de uso cotidiano. Compreensão de fenômenos climáticos relacionados ao ciclo da água.

\subsection{Química}

- Transformações químicas - Evidências de transformações químicas. Interpretando transformações químicas. Sistemas gasosos: Lei dos gases. Equação geral dos gases ideais, Princípio de Avogadro, conceito de molécula; massa molar, volume molar dos gases. Teoria cinética dos gases. Misturas gasosas. Modelo corpuscular da matéria. Modelo atômico de Dalton. Natureza elétrica da matéria: Modelo Atômico de Thomson, Rutherford, Rutherford-Bohr. Átomos e sua estrutura. Número atômico, número de massa, isótopos, massa atômica. Elementos químicos e Tabela Periódica. Reações químicas.

- Representação das transformações químicas - Fórmulas químicas. Balanceamento de equações químicas. Aspectos quantitativos das transformações químicas. Leis ponderais das reações químicas.

Determinação de fórmulas químicas. Grandezas químicas: massa, volume, mol, massa molar, constante de Avogadro. Cálculos estequiométricos.

- Materiais, suas propriedades e usos - Propriedades de materiais. Estados físicos de materiais.

Mudanças de estado. Misturas: tipos e métodos de separação. Substâncias químicas: classificação e características gerais. Metais e ligas metálicas. Ferro, cobre e alumínio. Ligações metálicas. 
Substâncias iônicas: características e propriedades. Substâncias iônicas do grupo: cloreto, carbonato, nitrato e sulfato. Ligação iônica. Substâncias moleculares: características e propriedades.

Substâncias moleculares: H2, O2, N2, Cl2, NH3, H2O, HCl, CH4. Ligação covalente. Polaridade de moléculas. Forças intermoleculares. Relação entre estruturas, propriedade e aplicação das substâncias.

- Água - Ocorrência e importância na vida animal e vegetal. Ligação, estrutura e propriedades.

Sistemas em solução aquosa: soluções verdadeiras, soluções coloidais e suspensões. Solubilidade.

Concentração das soluções. Aspectos qualitativos das propriedades coligativas das soluções. Ácidos, bases, sais e óxidos: definição, classificação, propriedades, formulação e nomenclatura. Conceitos de ácidos e bases. Principais propriedades dos ácidos e bases: indicadores, condutibilidade elétrica,

reação com metais, reação de neutralização.

- Transformações químicas e energia - Transformações químicas e energia calorífica. Calor de reação. Entalpia. Equações termoquímicas. Lei de Hess.Transformações químicas e energia elétrica.

Reação de oxirredução. Potenciais padrão de redução. Pilha. Eletrólise. Leis de Faraday.

Transformações nucleares. Conceitos fundamentais da radioatividade. Reações de fissão e fusão nuclear. Desintegração radioativa e radioisótopos.

- Dinâmica das transformações químicas - Transformações químicas e velocidade. Velocidade de reação. Energia de ativação. Fatores que alteram a velocidade de reação: concentração, pressão, temperatura e catalisador.

- Transformação química e equilíbrio - Caracterização do sistema em equilíbrio. Constante de equilíbrio. Produto iônico da água, equilíbrio ácido-base e pH. Solubilidade dos sais e hidrólise.

Fatores que alteram o sistema em equilíbrio. Aplicação da velocidade e do equilíbrio químico no cotidiano.

- Compostos de carbono - Características gerais dos compostos orgânicos. Principais funções orgânicas. Estrutura e propriedades de hidrocarbonetos. Estrutura e propriedades de compostos orgânicos oxigenados. Fermentação. Estrutura e propriedades de compostos orgânicos nitrogenados. 
Macromoléculas naturais e sintéticas. Noções básicas sobre polímeros. Amido, glicogênio e celulose. Borracha natural e sintética. Polietileno, poliestireno, PVC, teflon, náilon. Óleos e gorduras, sabões e detergentes sintéticos. Proteínas e enzimas.

- Relações da Química com as tecnologias, a sociedade e o meio ambiente Química no cotidiano. Química na agricultura e na saúde. Química nos alimentos. Química e ambiente. Aspectos científico-tecnológicos, socioeconômicos e ambientais associados à obtenção ou produção de substâncias químicas. Indústria química: obtenção e utilização do cloro, hidróxido de sódio, ácido sulfúrico, amônia e ácido nítrico. Mineração e metalurgia. Poluição e tratamento de água. Poluição atmosférica. Contaminação e proteção do ambiente.

- Energias químicas no cotidiano - Petróleo, gás natural e carvão. Madeira e hulha. Biomassa.

Biocombustíveis. Impactos ambientais de combustíveis fósseis. Energia nuclear. Lixo atômico.

Vantagens e desvantagens do uso de energia nuclear.

\subsection{Biologia}

- Moléculas, células e tecidos - Estrutura e fisiologia celular: membrana, citoplasma e núcleo.

Divisão celular. Aspectos bioquímicos das estruturas celulares. Aspectos gerais do metabolismo celular. Metabolismo energético: fotossíntese e respiração. Codificação da informação genética.

Síntese protéica. Diferenciação celular. Principais tecidos animais e vegetais. Origem e evolução das células. Noções sobre células-tronco, clonagem e tecnologia do DNA recombinante. Aplicações de biotecnologia na produção de alimentos, fármacos e componentes biológicos. Aplicações de tecnologias relacionadas ao DNA a investigações científicas, determinação da paternidade, investigação criminal e identificação de indivíduos. Aspectos éticos relacionados ao desenvolvimento biotecnológico. Biotecnologia e sustentabilidade.

- Hereditariedade e diversidade da vida - Princípios básicos que regem a transmissão de características hereditárias. Concepções pré-mendelianas sobre a hereditariedade. Aspectos genéticos do funcionamento do corpo humano. Antígenos e anticorpos. Grupos sanguíneos, transplantes e doenças autoimunes. Neoplasias e a influência de fatores ambientais. Mutações gênicas e 
cromossômicas. Aconselhamento genético. Fundamentos genéticos da evolução. Aspectos genéticos da formação e manutenção da diversidade biológica.

- Identidade dos seres vivos - Níveis de organização dos seres vivos. Vírus, procariontes e eucariontes. Autótrofos e heterótrofos. Seres unicelulares e pluricelulares. Sistemática e as grandes linhas da evolução dos seres vivos. Tipos de ciclo de vida. Evolução e padrões anatômicos e fisiológicos observados nos seres vivos. Funções vitais dos seres vivos e sua relação com a adaptação desses organismos a diferentes ambientes. Embriologia, anatomia e fisiologia humana.

Evolução humana. Biotecnologia e sistemática.

- Ecologia e ciências ambientais - Ecossistemas. Fatores bióticos e abióticos. Habitat e nicho ecológico. A comunidade biológica: teia alimentar, sucessão e comunidade clímax. Dinâmica de populações. Interações entre os seres vivos. Ciclos biogeoquímicos. Fluxo de energia no ecossistema. Biogeografia. Biomas brasileiros. Exploração e uso de recursos naturais. Problemas ambientais: mudanças climáticas, efeito estufa; desmatamento; erosão; poluição da água, do solo e do ar. Conservação e recuperação de ecossistemas. Conservação da biodiversidade. Tecnologias ambientais. Noções de saneamento básico. Noções de legislação ambiental: água, florestas, unidades de conservação; biodiversidade.

- Origem e evolução da vida - A biologia como ciência: história, métodos, técnicas e experimentação. Hipóteses sobre a origem do Universo, da Terra e dos seres vivos. Teorias de evolução. Explicações pré-darwinistas para a modificação das espécies. A teoria evolutiva de Charles Darwin. Teoria sintética da evolução. Seleção artificial e seu impacto sobre ambientes naturais e sobre populações humanas.

- Qualidade de vida das populações humanas - Aspectos biológicos da pobreza e do desenvolvimento humano. Indicadores sociais, ambientais e econômicos. Índice de desenvolvimento humano. Principais doenças que afetam a população brasileira: caracterização, prevenção e profilaxia. Noções de primeiros socorros. Doenças sexualmente transmissíveis. Aspectos sociais da biologia: uso indevido de drogas; gravidez na adolescência; obesidade. Violência e segurança pública. Exercícios físicos e vida saudável. Aspectos biológicos do desenvolvimento sustentável.

Legislação e cidadania. 


\section{Ciências Humanas e suas Tecnologias}

- Diversidade cultural, conflitos e vida em sociedade - Cultura material e imaterial; patrimônio e diversidade cultural no Brasil. A conquista da América. Conflitos entre europeus e indígenas na América colonial. A escravidão e formas de resistência indígena e africana na América. História cultural dos povos africanos. A luta dos negros no Brasil e o negro na formação da sociedade brasileira. História dos povos indígenas e a formação sociocultural brasileira. Movimentos culturais no mundo ocidental e seus impactos na vida política e social.

- Formas de organização social, movimentos sociais, pensamento político e ação do Estado - Cidadania e democracia na Antiguidade; Estado e direitos do cidadão a partir da Idade Moderna; democracia direta, indireta e representativa. Revoluções sociais e políticas na Europa Moderna.

Formação territorial brasileira; as regiões brasileiras; políticas de reordenamento territorial. As lutas pela conquista da independência política das colônias da América. Grupos sociais em conflito no Brasil imperial e a construção da nação. O desenvolvimento do pensamento liberal na sociedade capitalista $\mathrm{e}$ seus críticos nos séculos XIX e XX. Políticas de colonização, migração, imigração e emigração no Brasil nos séculos XIX e XX. A atuação dos grupos sociais e os grandes processos revolucionários do século XX: Revolução Bolchevique, Revolução Chinesa, Revolução Cubana.

Geopolítica e conflitos entre os séculos XIX e XX: Imperialismo, a ocupação da Ásia e da África, as Guerras Mundiais e a Guerra Fria. Os sistemas totalitários na Europa do século XX: nazi-fascista, franquismo, salazarismo e stalinismo. Ditaduras políticas na América Latina: Estado Novo no Brasil e ditaduras na América. Conflitos político-culturais pós-Guerra Fria, reorganização política internacional e os organismos multilaterais nos séculos XX e XXI. A luta pela conquista de direitos pelos cidadãos: direitos civis, humanos, políticos e sociais. Direitos sociais nas constituições brasileiras. Políticas afirmativas. Vida urbana: redes e hierarquia nas cidades, pobreza e segregação espacial.

- Características e transformações das estruturas produtivas - Diferentes formas de organização da produção: escravismo antigo, feudalismo, capitalismo, socialismo e suas diferentes experiências. 
Economia agroexportadora brasileira: complexo açucareiro; a mineração no período colonial; a economia cafeeira; a borracha na Amazônia. Revolução Industrial: criação do sistema de fábrica na Europa e transformações no processo de produção. Formação do espaço urbano-industrial.

Transformações na estrutura produtiva no século XX: o fordismo, o toyotismo, as novas técnicas de produção e seus impactos. A industrialização brasileira, a urbanização e as transformações sociais e trabalhistas. A globalização e as novas tecnologias de telecomunicação e suas consequências econômicas, políticas e sociais. Produção e transformação dos espaços agrários. Modernização da agricultura e estruturas agrárias tradicionais. O agronegócio, a agricultura familiar, os assalariados do campo e as lutas sociais no campo. A relação campocidade.

- Os domínios naturais e a relação do ser humano com o ambiente - Relação homem-natureza, a apropriação dos recursos naturais pelas sociedades ao longo do tempo. Impacto ambiental das atividades econômicas no Brasil. Recursos minerais e energéticos: exploração e impactos. Recursos hídricos; bacias hidrográficas e seus aproveitamentos. As questões ambientais contemporâneas: mudança climática, ilhas de calor, efeito estufa, chuva ácida, a destruição da camada de ozônio. A nova ordem ambiental internacional; políticas territoriais ambientais; uso e conservação dos recursos naturais, unidades de conservação, corredores ecológicos, zoneamento ecológico e econômico.

Origem e evolução do conceito de sustentabilidade. Estrutura interna da terra. Estruturas do solo e do relevo; agentes internos e externos modeladores do relevo. Situação geral da atmosfera e classificação climática. As características climáticas do território brasileiro. Os grandes domínios da vegetação no Brasil e no mundo.

- Representação espacial - Projeções cartográficas; leitura de mapas temáticos, físicos e políticos; tecnologias modernas aplicadas à cartografia. 


\subsection{Apêndice 2}

\subsubsection{Tabelas para consulta diferente do Estado do Rio de janeiro}

As tabelas mostram como se apresentam os cabeçalhos das colunas nos microdados do ENEM 2012. No arquivo Dicionário cada item tem a sua explicação. Ao baixar o arquivo é conveniente excluir as tabelas que não interessam ao leitor, assim, o tamanho do arquivo diminui consideravelmente.

Tabela 3 - Dados do aluno.

\begin{tabular}{|l|l|l|}
\hline NU_INSCRICAO & ST_CONCLUSAO \\
\hline NU_ANO & & ANO_CONCLUIU \\
\hline IDADE & & TP_ESCOLA \\
\hline TP_SEXO & & IN_TP_ENSINO \\
\hline COD_MUNICIPIO_INSC & & TP_ESTADO_CIVIL \\
\hline NO_MUNICIPIO_INSC & & TP_COR_RACA \\
\hline UF_INSC & & \\
\hline
\end{tabular}

Tabela 4 - Necessidades do aluno.

\begin{tabular}{|l|l|}
\hline IN_UNIDADE_HOSPITALAR & IN_AUTISMO \\
\hline IN_BAIXA_VISAO & IN_SABATISTA \\
\hline IN_CEGUEIRA & IN_BRAILLE \\
\hline IN_SURDEZ & IN_AMPLIADA \\
\hline IN_DEFICIENCIA_AUDITIVA & IN_LEDOR \\
\hline IN_SURDO_CEGUEIRA & IN_ACESSO \\
\hline IN_DEFICIENCIA_FISICA & IN_TRANSCRICAO \\
\hline IN_DEFICIENCIA_MENTAL & IN_LIBRAS \\
\hline IN_DEFICIT_ATENCAO & IN_LEITURA_LABIAL \\
\hline IN_DISLEXIA & IN_MESA_CADEIRA_RODAS \\
\hline IN_GESTANTE & IN_MESA_CADEIRA_SEPARADA \\
\hline IN_LACTANTE & IN_APOIO_PERNA \\
\hline IN_IDOSO & IN_GUIA_INTERPRETE \\
\hline
\end{tabular}


Tabela 5 - Dados do Colégio.

\begin{tabular}{|l|l|}
\hline IN_CERTIFICADO & ID_DEPENDENCIA_ADM \\
\hline NO_ENTIDADE_CERTIFICACAO & ID_LOCALIZACAO \\
\hline UF_ENTIDADE_CERTIFICACAO & SIT_FUNC \\
\hline PK_COD_ENTIDADE & COD_MUNICIPIO_PROVA \\
\hline COD_MUNICIPIO_ESC & NO_MUNICIPIO_PROVA \\
\hline NO_MUNICIPIO_ESC & UF_MUNICIPIO_PROVA \\
\hline UF_ESC & \\
\hline
\end{tabular}

Tabela 6 - Presença, nota, resposta, $n^{\circ}$ da prova, lingua estrangeira e gabarito em cada área.

\begin{tabular}{|l|l|l|}
\hline IN_PRESENCA_CN & & TX_RESPOSTAS_MT \\
\hline IN_PRESENCA_CH & & ID_PROVA_CN \\
\hline IN_PRESENCA_LC & & ID_PROVA_CH \\
\hline IN_PRESENCA_MT & & ID_PROVA_LC \\
\hline NU_NT_CN & & ID_PROVA_MT \\
\hline NU_NT_CH & & TP_LINGUA \\
\hline NU_NT_LC & DS_GABARITO_CN \\
\hline NU_NT_MT & DS_GABARITO_CH \\
\hline TX_RESPOSTAS_CN & DS_GABARITO_LC \\
\hline TX_RESPOSTAS_CH & DS_GABARITO_MT \\
\hline TX_RESPOSTAS_LC & IN_STATUS_REDACAO \\
\hline
\end{tabular}

Tabela 7 - Nota em cada competência e nota final em Redação.

\begin{tabular}{|l|l|}
\hline NU_NOTA_COMP1 & NU_NOTA_COMP4 \\
\hline NU_NOTA_COMP2 & NU_NOTA_COMP5 \\
\hline NU_NOTA_COMP3 & NU_NOTA_REDACAO \\
\hline
\end{tabular}

Ao abrir o arquivo cada arquivo:

h) Marque a primeira linha e na aba Dados clique em filtro (Figura 37). 
i) Na coluna PK_COD_ENTIDADE clique na seta e ao abrir a caixa de busca escreva o Código do Colégio no Educasenso (Figura 38).

j) Copie a planilha relativa ao colégio e cole numa nova planilha.

k) Este processo deve ser repetido em todas as planilhas do arquivo.

1) Dê um nome a sua planilha, por exemplo, COLEGIO_XX , e salve-a.

m) Exclua as colunas com os dados que não lhe interessa, assim, o arquivo ficará menor.

n) Mantenha o número do aluno, a nota de cada área, a nota de cada Competência da Redação, as respostas de cada área e o gabarito de cada área, o número referente a cada prova, eles estão relacionados às cores das provas.

o) "Na coluna nota, selecione todas as células, na aba selecionar e substituir, em localizar coloque " " e, em substituir coloque "," Assim estará garantindo que os dados são números e não texto. 